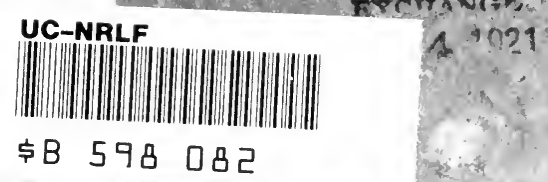

ude unvergity of Cbicago

\title{
FLAUBERT AND MAUPASSANT: A LITERARY RELATIONSHIP
}

\section{A DISSTRTATION}

SUBMITTED TO THE FACULTY

OF THE GRADUATE SCIOOI, OF AR'IS AND LIT,RATLRE.

IN CANDIDACY FI:R THE DEGREE OF

DOCTOR OF PISI.OSOYHY

DEPARTMENT OF ROMANCE LANGUAGES AND LIHAA A 'RF'

BY

A. NUTHERFORD RIDDELI

THE UNIVERSITY OF CHICAGO PRESS

CHICAGO, ILLINOIS 

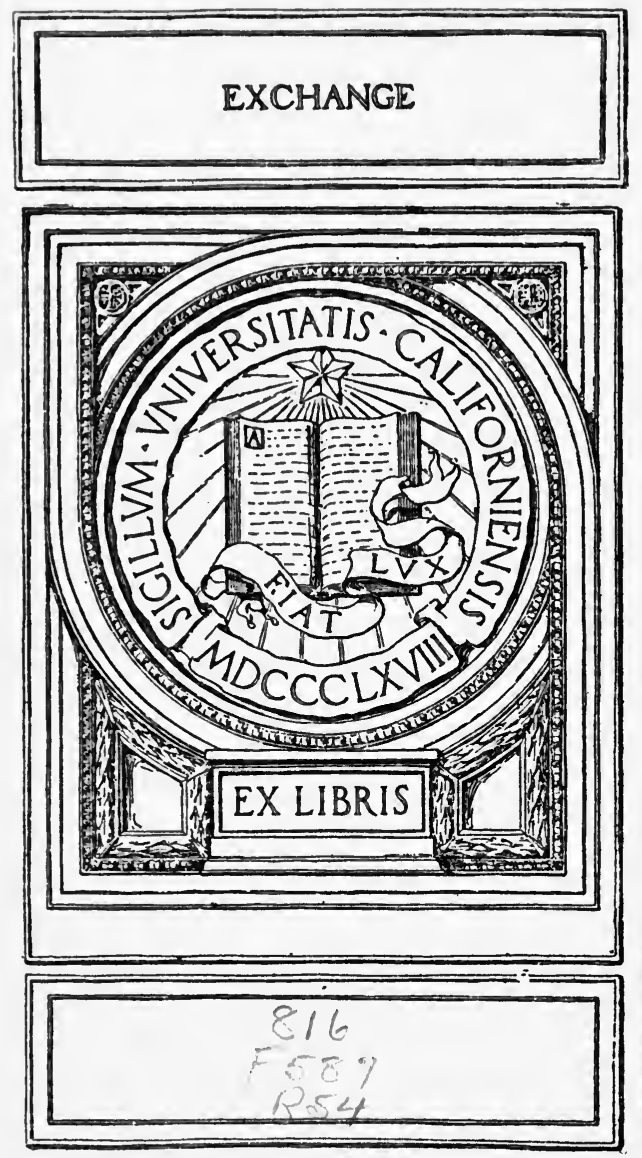
ro 



\title{
FLAUBERT AND MAUPASSANT: A LITERARY RELATIONSHIP
}

\author{
A DISSERTATION \\ SUBMITTED TO THE FACULTY \\ OF THE GRADUATE SCHOOL OF ARTS AND LITERATURE \\ IN CANDIDACY FOR THE DEGREE OF \\ DOCTOR OF PHILOSOPHY
}

DEPARTMENT OF ROMANCE LANGUAGES AND LITERATURES

BY

AGNES RUTHERFORD RIDDELL

THE UNIVERSITY OF CHICAGO PRESS

CHICAGO, ILLINOIS 
Copyright $1920 \mathrm{BY}$

The University of Chicago

\section{All Rights Reserved}

Published February r920

\section{Excruane:}

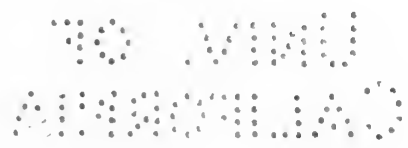

Composed and Printed By The University of Chicago Press Chicago, Illinois, U.S.A. 


\section{PREFACE}

The publication of this dissertation has been delayed by the war, as it has been impossible to visit the libraries of Europe for books and articles not to be found on this side of the Atlantic. Permission to publish has now been granted the writer by the Department of Romance Languages and Literatures, with the understanding that, if necessary, additions to or revisions of the dissertation may be issued by her after she has examined the material in Europe.

This dissertation has been written under the direction of Professor E. P. Dargan, to whose invaluable and untiring encouragement and counsel the writer acknowledges with pleasure her very great indebtedness. She desires further to express her thanks for much valuable advice to Professor Nitze, head of the Department of Romance Languages and Literatures. To Professor Pietsch, Professor Jenkins, Professor Wilkins, Professor Coleman, Assistant Professor Parmenter, and others who have assisted her from time to time during the composition of the dissertation with facts and suggestions, she wishes also to record her gratitude.

\section{1}




\section{Digitized by the Internet Archive in 2008 with funding from Microsoft Corporation}




\section{TABLE OF CONTENTS}

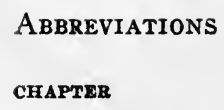

I. History of the Personal Relationship . . . . . I

II. Discussion and Exemplification of Definitely Stated Theories Regarding Life (With Introduction) • . II

III. Discussion and Exemplification of Definitely Stated Theories Regarding Literary Procedure • . . . 21

IV. Likeness in Employment of General Realistic Devices . 38

V. Resemblances in Plot, Incident, Characterization, Ideas AND WORDING . . . . . . . . . . . . . 63

Vi. Summary and Conclusion . . . . . . . . . . . . . . BIBLIOGRAPHY • • • . • • • • . • • • • III 



\section{ABBREVIATIONS}

In referring to the works of Flaubert and Maupassant, the following abbreviations are used throughout the notes of the dissertation in order to save space. Where the reference is to a short story, the title of the volume in which it is contained is given first, and then the name of the story (abbreviated in many cases).

\section{Flaubert}

M.B. . . . . . . Madame Bovary

L'Ed.S • . . . . L'Education sentimentale

Sal. . . . . . . . Salammbô

T.C. (U.C.S.; L.L.d.S.J.l'H ; Trois Contes (Un Coeur simple; La Légende Hér.) . . . . de Saint Julien l'Hospitalier, Hérodias)

L.T.d.S.-A. . . . . . La Tentation de Saint-Antoine

O.d.J. . . . . . Oeuvres de jeunesse

N.d.V. . . . . . . Notes de voyages

P.l.C.e.p.l.G. . . . . Par les Champs et par les Grèves

Corr. . . . . . . Correspondance

B.e.P. . . . . . . Bouvard et Pécuchet

\section{MaUpassant}

D.V. . . . . . . Des Vers

B.d.S. . . . . . Boule de Suif

P.e.J. . . . . . . . Pierre et Jean

Mlle.F. . . . . Mademoiselle Fifi

M.Par. . . . . . . Monsieur Parent

L.R.d.M.H. . . . Le Rosier de Madame Husson

Au S. . . . . . . Au Soleil

L.M.G. . . . . . La Main Gauche

U.V. . . . . . . . Une Vie

L.P.R. . . . . . La Petite Roque

S.l'E. • . . . . . Sur l'Eau

F.c.l.M. . . . . . Fort comme la Mort

N.C. . . . . . . Notre Coeur

L.M.T. . . . . . La Maison Tellier

L.V.E. . . . . . La Vie Errante

L.H. . . . . . . Le Horla

C.d.1.B or Béc. . . . . Contes de la Bécasse 
O.P. . . . . . . Oeuvres posthumes

M.Har. . . . . . Miss Harriet

L.S.R. . . . . . Les Soeurs Rondoli v

M.-O. . . . . . . . Mont-Oriol

C.d.J.e.d.I.N. . . . . Contes du Jour et de la Nuit

L'I.B. . . . . . L'inutile Beauté

B.-A. . . . . . Bel-Ami

C.d.L. . . . . . . Clair de Lune

Italicized words in quotations marked thus ${ }^{*}$ are italicized in the text. Where this mark is not used the italics are the writer's. 


\section{CHAPTER I}

\section{HISTORY OF THE PERSONAL RELATIONSHIP}

Flaubert's connection with the Maupassant family began through the friendship between his mother and the mother of his companions, Alfred and Laure Le Poittevin, ${ }^{1}$ the latter of whom became, in 1850 , the mother of Guy de Maupassant. ${ }^{2}$ The relationship with Alfred Le Poittevin continued until the latter's death in $1848,{ }^{3}$ as is evidenced by the frequent mention of him in the Correspondance and elsewhere in Flaubert's works, ${ }^{4}$ by the letters addressed to him, ${ }^{5}$ and by the dedication to him of La Tentation de Saint-Antoine and of two youthful attempts. ${ }^{\circ}$ Some years older than Gustave, Alfred Le Poittevin seems to have had upon him considerable influence. For present purposes the friendship is interesting mainly because it gives rise to the speculation as to how far Flaubert's relationship with the nephew is traceable to his friendship with the uncle.

With Laure Le Poittevin, who married, in I846, Gustave de Maupassant, Flaubert maintained his friendship as long as he lived.? She seems, however, to have passed out of his ken during the early years of her married life. ${ }^{8}$ The first letter to her included in the Correspondance dates from $1863 .{ }^{\circ}$ Others follow in 1866,1872 , and 1873 (2). ${ }^{10}$ In these letters reference is made to Alfred; mention also occurs of Laure's son Guy and of the growing affection of Flaubert for him, partly on the lad's own account and partly because

1 Flaubert, Corr., I: Souvenirs intimes de Mme. de Commanville, p. ix.

${ }^{2}$ Maynial, La vie et l'oeuvre de Maupassant, p. 24.

3 Ibid., p. 2 r.

${ }^{4}$ For example, Corr., I, 24, 33, 35, 39, 45, 54, 60, 62, 74, 77, 96, 167, 191, 207, 298, 301, 402, 459; II, 23, 92, I9I-93; N.d.V., I, 89; P.l.C.e.p.l.G., pp. 337, 339, etc.

${ }^{5}$ Corr., I, I47, I50, I53, I59, I62, I73 (1845), I87, I88 (1846).

${ }^{6}$ O.d.J., I, $40 \mathrm{I}$; II, $12 \mathrm{I}$.

${ }^{7}$ Maynial, op. cit., pp. 23 and 2r. Maynial gives a very full account of the personal relationship between Flaubert and Maupassant, to which the present chapter is much indebted. The acknowledgment is made here once for all, except in the case of specific references.

${ }^{8}$ Ibid., p. $22 . \quad 9$ Corr., III, 384, 4 I8; IV, 138, 158, $185 . \quad{ }^{10} \mathrm{Ibid}$. 
of his strong resemblance to his uncle. ${ }^{11}$ This is the beginning of a letter in Correspondance, IV, 158 :

Tu m'as prévenu, ma chère Laure, car depuis un mois je voulais t'écrire pour te faire une déclaration de tendresse à l'endroit de ton fils. $\mathrm{Tu}$ ne saurais croire comme je le trouve charmant, intelligent, bon enfant, sensé et spirituel, bref (pour employer un mot à la mode) sympathique! Malgré la différence de nos âges je le regarde comme «un ami,» et puis il me rappelle tant mon pauvre Alfred! J'en suis même parfois effrayé, surtout lorsqu'il baisse la tête, en récitant des vers.

Flaubert advises her to encourage her son in his taste for verse writing and holds out hope that in time the young man may accomplish something worthy of literary fame. In a letter in Correspondance (IV, I85), Flaubert again expresses his affection for Guy and declares himself willing to do all in his power to help him.

The letters to Guy de Maupassant himself included in the Correspondance begin in 1873 and continue until the year of Flaubert's death. They are thirty-seven in number ${ }^{12}$ and contain criticism, warning, and advice regarding literary and other matters, requests for information and for counsel, explanation of commissions to execute, thanks for services rendered, messages to Mme de Maupassant and to friends, accounts of the older man's own doings, and current gossip. In one Flaubert calls Guy "mon très aimé disciple."13 Another is a species of manifesto on the relation of art to morality. It upholds "le culte de la femme" on the authority of great writers of ancient and modern times and enunciates the theories, to be discussed in later chapters of this thesis, of "art for art's sake," and of the persecution of literature by the public. ${ }^{14}$ This epistle, cast in a tone of ironic exasperation at the "bêtise" of the prosecution occasioning the letter, was written for insertion in the Gaulois to defend Maupassant against a threatened lawsuit, brought on by the unauthorized publication of fragments from one of his poems. It now appears, somewhat changed, as a preface to the latter's volume of verses. ${ }^{15}$ The personal literary advice contained in the

${ }^{11}$ Corr., IV, 185.

12 Corr., IV, 166, 223, 266, 269, 273, 278, 285, 313, 315, 319, 335, 345, 346, 349, $350,357,363,382,386,388,391,396,397,401,405,411,414,417,418,423,425,427$, 427, 428, 429, 430, 431 .

${ }^{13}$ Corr., IV, 391.

${ }^{14}$ See below, pp. 36, 20. ${ }^{15}$ D.V., pp. xxvii-xxxi. 
letters is valuable here because it throws light upon the method of training to which Flaubert subjected his pupil. The older man shows keen interest in everything written by the younger and is constantly asking for news of his efforts̀. When Maupassant is trying to secure a position on the journals, Flaubert suggests to him subjects for articles. ${ }^{16}$ An article on himself wins his thanks; another is "fine," a third "good." 17 The last-mentioned, however-on French poetry-does not do justice to Ronsard. Remarks on individual works are very specific, praise being tempered with blame. The following are examples of generally commendatory criticism.

C'est très bien votre Vénus.* Je n'y vois rien à reprendre que deux petites incorrections grammaticales, mais elles peuvent se défendre. ${ }^{18}$

Quant à votre $m u r, * 10$ plein de vers splendides, il y a des disparates de ton. Ainsi le mot bagatelle* vous verse une douche glacée. L'effet comique arrive trop tôt, mais admettons que je n'aie rien dit; il faut voir l'ensemble. ${ }^{20}$

The following passage is a sample of severe criticism. Although somewhat long, it is quoted in its entirety because it shows with what vigorous censure the master corrected the disciple on occasion.

Maintenant causons de Désirs.* Eh bien! mon jeune homme, la dite pièce ne me plait pas du tout. Elle indique une facilité déplorable.

Un de mes chers désirs,* un désir qui est cher! Avoir des ailes,* parbleu! le souhait est commun. Les deux vers suivants sont bons, mais au quatrième les oiseaux surpris* ne sont pas surpris puisque tu es à les poursuivre. A moins que surpris ne veuille dire étonnés?

16 For example, Corr., IV, 274. The numerous articles which Maupassant wrote for reviews and journals have, with few exceptions, never been reprinted (Maynial, op. cit., p. 213). It is impossible, therefore, at the present moment, for the writer of this thesis to say from personal observation how far these suggestions of Flaubert's were carried out.

Mahn, Guy de Maupassant, sein Leben und seine Werke, gives, in his chapter entitled "Der Journalist," pp. 125-66, an account of his researches on the subject of these articles at the Bibliothèque Nationale. Maupassant wrote especially for Le Gaulois and Le Gil Blas, as well as for numerous other journals. The content of the articles, as described by Mahn, does not differ in kind from that of the author's collected works.

$$
{ }^{17} \text { Corr., IV, 273, 319, } 285 . \quad{ }^{18} \text { Corr., IV, } 386 .
$$

${ }^{19} \mathrm{~A}$ reference apparently to Maupassant's poem Le Mur. The word mur is printed in the Conard edition of Flaubert's Correspondance with a small letter.

${ }^{20}$ Corr., IV, 397. 
Je voudrais, je voudrais.* Avec une pareille tournure on peut aller indéfiniment tant qu'on a de l'encre! Et la composition? Ou est-elle?

Ainsi qu'un grand fambeau,* l'image me semble comique; outre qu'un flambeau ne laisse pas de flamme, puisqu'il la porte.

Des fronts en cheveux noirs aux fronts en cheveux roux.

Charmant, mais rappelle trop le vers de Ménard:

Sous tes cheveux châtains et sous tes cheveux gris.

«Oui je voudrais.» Pourquoi oui?*

Clair de lune* excellent.

L'affolante bataille,* atroce!

En somme je t'engage à supprimer cette pièce, elle n'est pas à la hauteur des autres.

Là-dessus ton vieux t'embrasse. Sévère, mais juste. ${ }^{21}$

In the foregoing three passages the form of criticism is that of specific comment, with some general remarks. No point is allowed to pass which offends against Flaubert's uncompromising standards of originality, of correctness, of artistic fitness. Vénus, for example, contains "two slight grammatical errors." The word "bagatelle" in le Mur has "a chilling effect." The poem Désirs shows "a deplorable facility." Avoir des ailes is a commonplace expression. The word "surpris" is ambiguous, the word "oui" superfluous. The image of the torch is inappropriate. The line quoted is a plagiarism. And so on. The strictures on these poems illustrate certain of Flaubert's literary theories which will be considered later in this thesis, as, for instance, his insistence on the "mot juste," his dislike of "idées reçues," etc. ${ }^{22}$ As the poems now appear in the volume Des Vers we may observe that the expressions criticized have generally been altered, ${ }^{23}$ showing Maupassant's deference to the opinions of Flaubert.

In commenting on Boule de Suif, the "conte rouennais" concerning which Maupassant had apparently thrown out mysterious hints before its appearance in the Soirées de Médan, Flaubert is most enthusiastic. ${ }^{24}$ It is the best thing in the volume, a real masterpiece, original, well thought out, excellently written. Land-

${ }^{21}$ Corr., IV, 424. The poem was not "suppressed," as it appears in the volume Des Vers (pp. 67-68), but some of the expressions censured have been changed.

${ }^{22}$ See below, pp. 28-31, 27.

${ }^{23}$ Cf. Maynial, op. cit., p. 89; D. V., pp. 67-68.

${ }^{24}$ Corr., IV, 392, 397-99. 
scapes and characters are vividly conceived; the psychology is "strong"; Cornudet is "immense et vrai"; the nun with the smallpox marks on her face is "parfaite"; the scene where Boule de Suif weeps while Cornudet sings the "Marseillaise" is "sublime." Then comes the minute reservation of the conscientious mentor:

Eh bien, précisément* parce que c'est raide de fond et embêtant pour les bourgeois, j'enlèverais deux choses, qui ne sont pas mauvaises du tout, mais qui peuvent faire crier les imbéciles, parce qu'elles ont l'air de dire: "Moi je m'en $\mathrm{f} \_$": $\mathrm{I}^{\circ}$ dans quelles frises, etc., ce jeune homme jette de la fange à nos armes; et $2^{\circ}$ le mot tetons.* Après quoi le goût le plus bégueule n'aurait rien à vous reprocher [p. 398].

In a subsequent letter, after saying that he has re-read Boule de Suif, Flaubert adds: "Tâche d'en faire une douzaine comme ca! et tu seras un homme!"25 Such advice gives some ground for the remark of Mme de Maupassant, quoted farther on, ${ }^{26}$ that it was Flaubert who wished to make a novelist of her son. ${ }^{27}$ That the older man personally knew the young Guy mainly as a writer of verses and an aspirant for dramatic honors, especially the former, is true, however, as one can gather from what Maynial says ${ }^{28}$ and from the comments in the letters. Maupassant tells us that he tried his hand at all kinds of composition during his seven years' apprenticeship. ${ }^{29}$ Verse writing nevertheless seems to have predominated. His early fondness for this form may be, in part, a residue from the influence of Bouilhet, under which he passed two years before he knew Flaubert. ${ }^{30}$ Maynial suggests also that verse came more spontaneously than prose to Maupassant, and satisfied better than prose the young writer's desire for immediate productiveness. ${ }^{31}$ There is a certain tone of curiosity or of delighted surprise in Flaubert's remarks on Boule de Suif which seems to indicate that the pupil had exceeded the master's expectations, giving hints of possibilities hardly suspected hitherto. Hence the advice to aim, if possible, at persistence in the same type of performance. Meanwhile references to the verses continue. When the volume Des Vers appears shortly after the publication of the Soirées de Médan, Flaubert expresses his approval, ${ }^{32}$ as he has done in the case of

${ }^{25}$ Corr., IV, 426.

26 See below, p. 7.

${ }^{27}$ D. V., p. xxi ; Maynial, op. cit., p. 44.

28 Ibid., p. 80.
${ }^{29}$ See below, p. 9.

30.P.e.J.: «Le Roman», p. xxii.

31 Maynial, op. cit., p. 80.

32 Corr., IV, 427. 
Boule de Suif. What pleases him about this effort is that it is "personal" and does not adopt the formula of any school. "Pas de chic! pas de pose! ni parnassien, ni réaliste (ou impressioniste, ou naturaliste)." (Flaubert especially detested these modern shibboleths.) He wishes Maupassant to collect for him everything that is published on Boule de Suif and on the verses. ${ }^{33}$ In this we see the eager interest of the master in a favorite disciple.

We have given examples of Flaubert's specific criticism of Maupassant; more general literary advice is not lacking. Guy must not allow his mode of life to interfere with his art. A man who aspires to the name of "artist" has no right to live as do others; his only principle must be the necessity of sacrificing everything to art. He warns the young man also against brooding and conjures him to work harder. "Il faut,* entendez-vous, jeune homme, il faut* travailler plus que ça. ... Vous êtes né pour faire des vers, faites-en!"34

Another form of literary training probably not less important than the above-mentioned, because it furnished the example to establish the precept, is emphasized by Maynial. ${ }^{35}$ Flaubert associated his pupil with himself in the composition of Bouvard et Pécuchet, seeking from him precise information on many points and detailing at length his own efforts toward accuracy and precision. For instance, he needs for a particular episode in his story a certain kind of hillside slope, and Maupassant must suggest to him a place near Havre which will fulfil the requirements. ${ }^{36}$ Or the young man becomes the confidant of Flaubert's chagrin at M. Baudry's questioning of his botanical exactness. ${ }^{37}$ Other examples of a like nature are to be found in the Correspondance.

In letters from Flaubert to various persons during the later years of his life there is frequent mention of Maupassant and of the young man's mother, the former being often called "mon disciple," occasionally "mon élève." 38 These letters are sometimes written to help the beginner in his prospects, or refer to Guy's doings and to the writer's interest in him. ${ }^{39}$

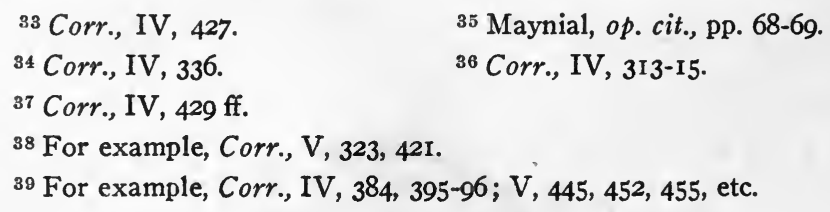


Besides the letters of Flaubert there are several from Mme de Maupassant and from her son to their common friend which give evidence of the relationship between the two men. In the "Notes" to the volume containing Flaubert's Théatre there is an epistle by Mme de Maupassant in which she speaks of the friendship and says, "Comme le disciple appartient au maitre!"40 In the volume of Maupassant's verses there are some letters from his mother to Flaubert in which she often mentions her two sons, refers to her anxiety regarding Guy's future, asks for her old friend's advice and assistance in the matter, thanks him for his kindness to the young man, or assures him of the latter's affection. ${ }^{41}$ In one place she speaks of Flaubert's having called Guy his "fils adoptif"; in another she says, "C'est Flaubert qui voulut en faire un romancier." 42 The likeness to the uncle, Alfred Le Poittevin, is referred to by her, ${ }^{43}$ as well as by Flaubert's mother in a short note preceding the selections from Maupassant's correspondence in the volume entitled Boule de Suif. ${ }^{44}$ In the same volume are included some letters of Maupassant's to Flaubert, ${ }^{45}$ in which he generally addresses the latter as "mon cher maitre" and speaks of missing their "causeries de chaque semaine." $\mathrm{He}$ asks for advice or gives information regarding what he is writing and recounts the events of his official life, his efforts to obtain a place on the journals, the happenings about him, news of mutual friends. In the other letters of Maupassant-letters to his mother and his friends-there are various short personal references to Flaubert. ${ }^{47}$ The last instance of this dates from a time after the latter's death and reads as follows:

Je ne saurais vous dire combien je pense à Flaubert, il me hante et me poursuit. Sa pensée me revient sans cesse, j'entends sa voix, je retrouve ses gestes, je le vois à tout moment debout devant moi avec sa grande robe brune, et ses bras levés en parlant. C'est comme une solitude qui s'est faite autour de moi, le commencement des horribles séparations qui se continueront maintenant d'année en année, emportant tous les gens qu'on aime, ou qui sont nos souvenirs, avec qui nous pouvions le mieux causer des choses intimes. ${ }^{48}$

\footnotetext{
40 Flaubert, Théâtre, p. 515.

${ }^{41} D . V$., pp. ix-xxiii.

$42 D$. V., p. xxi ; Maynial, op. cit., p. 44 ; cf. above, p. 5.

${ }^{43} D . V$., pp. xi, xvi.

45 Ibid., pp. xcv-cxxiv.

44 B.d.S.: Corr., p. xciv.

46 Ibid., pp. xcv-cxiii, etc.

${ }^{47}$ For example, B.d.S.: Corr., pp. cxxxv, cxli, cxliii-iv.

48 B.d.S.: Corr., pp. cxliii-iv.
} 
We see in this passage how the very memory of Flaubert seems to evoke the keen mental vision of individual characteristics which the master advocated, ${ }^{49}$ as well as to call forth the sense of isolation and of the imminence of death which constantly overshadowed Maupassant's outlook on life. ${ }^{50}$ It will be observed that the closing words suggest a relationship of mental sympathy.

Also to be noted, from the point of view of the one author's influence on the other, are certain additional direct statements of Maupassant's. After the letter-preface to the verses there appeared, in the third edition of the volume, a few lines on Flaubert's death, which had occurred very shortly before. In them Maupassant pays the following tribute to his friend:

Depuis que ce livre a paru (il y a un mois à peine) le merveilleux écrivain à qui il était dédié est mort, Gustave Flaubert est mort.

Je ne veux point ici parler de cet homme de génie, que j'admire avec passion, et dont je dirai plus tard la vie quotidienne, et la pensée familière, et le coeur exquis, et l'admirable grandeur.

Mais, en tête de la nouvelle édition de ce volume «dont la dédicace l'a fait pleurer,» m'écrivait-il, car il m'aima aussi, je veux reproduire la superbe lettre qu'il m'adressa pour défendre un de mes poèmes: $A u$ bord de l'eau, ${ }^{* 51}$ contre le parquet d'Etampes qui m'attaquait.

Je fais cela comme un suprême hommage à ce mort, qui a emporté assurément la plus vive tendresse que j'aurai pour un homme, la plus grande admiration que je vouerai à un écrivain, la vénération la plus absolue que m'inspirera jamais un être quel qu'il soit.

These paragraphs have been quoted because they show, especially in the expressions italicized, the grateful affection and the extravagant admiration with which Maupassant regarded Flaubert-an affection and admiration which would lead naturally to the influencing of the one writer by the other, even without the close connection of master and disciple which has been noted as existing between them.

To the intimacy of this relationship Maupassant himself bears witness in his article on "Le Roman," printed at the beginning of the volume entitled Pierre et Jean. He tells how he ventured to submit some of his attempts to Flaubert; how the latter kindly read them

${ }^{49}$ See below, pp. 25-26. 50 See below, p. 15 .

${ }^{51} \mathrm{Cf}$. on this point Maynial, op. cit., pp. 84-85, 89-96. There is some confusion in the references to the poem. 
and encouraged him to hope that time and work would reveal the possession of talent by their author. For seven years thereafter the master labored with the disciple. The story is told in Maupassant's own words :

Pendant sept ans je fis des vers, je fis des contes, je fis des nouvelles, je fis même un drame détestable. Il n'en est rien resté. Le maitre lisait tout, puis le dimanche suivant, en déjeunant, développait ses critiques et enfonçait en moi, peu à peu, deux ou trois principes qui sont le résumé de ses longs et patients enseignements. «Si on a une originalité. disait-il, il faut avant tout la dégager; si on n'en a pas, il faut en acquérir une.» ${ }^{52}$

We should take account of Maupassant's statement here that none of all the attempts of his seven years' apprenticeship was allowed to survive. We possess, therefore, in all probability, no further specimens than those already mentioned ${ }^{53}$ of the work done by him under the eye of the master. We must seek for the literary influence then in considerable measure, as Maupassant's remarks in the foregoing passage suggest, in the general application by the latter, throughout his subsequent work, of the principles inculcated by the former. What these are is indicated in the succeeding well-known paragraphs of the article from which quotation has already been made. ${ }^{54}$ They will be discussed in a subsequent chapter of this thesis. ${ }^{55}$

In I885 Maupassant wrote an article on Flaubert which served as a preface to the Quantin edition of Bouvard et Pécuchet. This has been inserted in Maupassant's Oeuvres Posthumes, II. Some account will be given of it in a subsequent section of this thesis. ${ }^{58}$ Maupassant's first published volume, containing his verses, was dedicated "à Gustave Flaubert, à l'illustre et paternel ami que j'aime de toute ma tendresse, à l'irréprochable maître que j'admire avant tous." This is the dedication which Maupassant says made Flaubert weep. ${ }^{57}$ Again, in his reply to M. Sarcey, Maupassant quotes Flaubert and others as being "justement irrités de la prétention des critiques d'imposer un genre aux romanciers." ${ }_{58}$ Finally, other references to his memories of Flaubert, not particularized now because not con-

52 P.e.J.: «L.R.», p. xxiii.

${ }^{53}$ See above, p. 8.

54 P.e.J.: $\ll L . R . »$, pp. xxiii-xxv.

${ }^{55}$ See below, pp. 21-37.

${ }^{56}$ See below, pp. 21 ff.

57 See above.

58 Mlle.F.; Appendix, p. 275. 
cerned with literary theory, are to be found here and there in his works. $^{59}$

In this chapter we have studied then the direct personal relationship between Gustave Flaubert and Guy de Maupassant. We have seen that it began through the general friendship of the Flaubert and Le Poittevin families, strengthened by the comradeship of Flaubert and Alfred Le Poittevin. The influence of the latter was still felt when Flaubert came to know Guy de Maupassant, the nephew, to whom he was attracted at first partly by his remembrance of the uncle. There soon grew up, however, between the older and the younger man a very strong mutual affection which led in time to the establishment of the master and pupil relationship. This affection was reinforced in the case of Maupassant by an admiration which led him to submit to a most rigorous censorship of his literary efforts, and which opened the way for Flaubert virtually to impose his own theories on the younger artist.

59 For example, M. Par., p. 264 ; L.R.d.M.H., pp. 239, 241-44; Au S., pp. 7 , 191, 196-97. 


\section{CHAPTER II}

\section{DISCUSSION AND EXEMPLIFICATION OF DEFINITELY STATED THEORIES REGARDING LIFE (WITH INTRODUCTION)}

Before going on to consider the theories of Flaubert and Maupassant regarding the world in general and literary matters in particular, it will be well to look for a short time at certain similarities in their lives which will have to be taken into account in tracing likenesses in their works. Both were Norman on the mother's side and passed their youth and much of their later life in Normandy. It was possible thus for them to obtain from personal observation that knowledge of Norman life, character, and landscape which they display. They were also acquainted with Parisian life, although not both to the same extent, and moved in Paris in the same literary circle.

Throughout life the two men were confronted by circumstances which tended to sadden. Flaubert spent his youth in close proximity to the sights and sounds of a hospital; Maupassant early gained a perception of the unfortunate relations existing between his father and mother. Both were unhappy in much of their school life and were in later days attacked by the law for alleged offences against morality in their works. Each passed through the shattering experiences of the War of 1870 , Flaubert as a national guard, ${ }^{1}$ Maupassant in the fighting force. For a considerable portion of their respective careers they lived lives of solitary laboriousness. Robust in early youth, they were subsequently assailed by maladies which embittered existence.

Besides all this, the tastes of the two men were similar in many respects. Each had a liking for the grotesquely comic. ${ }^{2}$ Both

${ }^{1}$ Corr., IV, 33, etc. The facts regarding the life of Flaubert are taken partly from the Souvenirs of Mme. de Commanville prefixed to Correspon. dance, I, and partly from the introductory note to Madame Bovary; those concerning Maupassant come from Maynial. Other authorities are indicated where necessary.

2 For example, Maxime du Camp, Souvenirs littêraires, I, I64-65, etc.; F. Brunetière, Le Roman naturaliste, pp. 402-3, etc. Maynial notes this characteristic in Maupassant. 
showed an early interest in literature, an especial fondness for Shakespeare, and a desire to try their hands at many forms of literary composition. They were friends of Louis Bouilhet, coming under his influence at the formative period. They delighted in nature. They had in common a passion for traveling and looked to the visiting of foreign scenes as a means of escape from irksome circumstances. It is interesting to note here that in the course of their travels they visited very much the same places-Algeria, Corsica, Sicily, Italy, Southern France, Switzerland, Brittany-so that we frequently find the same itinerary described by both. ${ }^{3}$

A very curious resemblance is the reciprocal attraction which they describe themselves as possessing toward men and women deprived of reason. ${ }^{4}$ In the case of Maupassant we naturally connect this with his subsequent madness ; in that of Flaubert it appears to be related to his 'morbid fondness for the abnormal and the grotesque.

In the light of all these similarities it would be strange if there were not coincidences in the works of the two, even without the literary friendship which we have studied in the previous chapter. We are met here by the difficulty of distinguishing the likenesses in their writings due to the influence of the one man upon the other from those which arise out of the general thought and practice of the epoch and school to which both belong. Resemblances then, to be of value in determining the extent of the relationship between the two authors, must be specific, showing agreement in form, or in content, or in both. In the succeeding pages of this thesis special attention will be paid to the more concrete instances of similarity.

Regarding the likenesses between the two authors the critics have comparatively little to say. The younger man is hailed on all sides as the disciple of the older; but the resemblance is not analyzed, or is analyzed only in the scantiest way. It is generally agreed that such influence as exists is observable chiefly in Maupassant's earlier work, before he had quite evolved his own method. Examples of the kind of comparison of the two to be discovered in criticism are as follows. Brunetière, in speaking of some earlier works of Maupassant's, says, "There is too much Flaubert in him." Lemaitre finds that the older

${ }^{3}$ See below, p. 84 .

${ }^{4}$ For example, N.d.V., I, 50 ; Corr., I, I64; L.M.g.: Madame Hermet, pp. 253-55.

5 Brunetière, Le Roman naturaliste, p. 342. 
man has influenced the younger in irony of general treatment and in precision of form. ${ }^{6}$ Again we have indication of certain books of Maupassant's or scenes therein which derive more or less directly from certain books or scenes of Flaubert's, as, for example, Une Vie from Madame Bovary, Bel-Ami from L'Education sentimentale, Olivier Bertin's excursion to the Champs-Elysées from that of Frédéric Moreau to the same place, ${ }^{7}$ and so on. Apart from such suggestions one can gain on the subject in hand little direct help from the critics.

There remains yet another point to be touched upon before proceeding to the discussion of similar theories. One conclusion regarding Guy de Maupassant which is of importance in connection with the question of influence-that he was not eminently inventiveforces itself upon us as we peruse his works. Over and over again we find repeated the same subjects, the same situations, the same characters, the same ideas, even the same wording. ${ }^{8}$ In order to recognize the truth of this assertion one has only to remember, for instance, how large a proportion of his work deals with illicit passion, with the circumstances of its indulgence, and with the men or women who are possessed by it. A constantly recurring idea is that of the uselessness of combating the fatality which binds humanity. ${ }^{9}$ A good example of similarity in wording is the passage describing a rustic ball, which is, used almost word for word in Ma Femme and in Une Vie. ${ }^{10}$ Much of this repetition is to be accounted for by the fact that Maupassant consciously circumscribed his range. ${ }^{11}$ It is also hardly surprising that a man who produced as much as he within the short space of eleven years, ${ }^{12}$ and who, in the nature of the case, must often have written hastily, ${ }^{13}$ should sometimes return upon himself. We have indication of lack of inventiveness in his letters, where we find him asking that subjects be suggested to him. ${ }^{14} \mathrm{He}$ also, according

${ }^{6}$ Lemaître, Les Contemporains, V, I-12.

${ }^{7}$ E.-L. Ferrère, L'Esthétique de Gustave Flaubert, pp. 254-55; Brunetière, Le Rom. Nat., pp. 342-43.

8 Cf. Maynial, La Composition dans les romans de Maupassant, R.B., XX (1903), 562-65, 604-8.

${ }^{9}$ For example, U.V., p. 323 ; L.p.R., p. 46 ; S.l'E., pp. 40-44; F.c.l.m., pp. 340$4 \mathrm{I}$; N.C., pp. 224-25; etc.

${ }^{10}$ L.M.T., pp. 267-68; U.V., pp. 79-80. ${ }^{11}$ P.e.J.: 《L.R.», pp. xi-xii.

12 The years 1880-90. See Maynial, La Vie et l'oeuvre de Maupassant, p. II9.

18 Ibid., pp. 120-21, 122-23.

14 B.d.S.: Corr., p. cxxxi. 
to the testimony of Doumic, ${ }^{15}$ drew extensively upon his own experience to supply him with material for writing. Here then, in the acceptance of suggestions afterwards to be worked out in his own way, we see possibilities for influence upon him. If any such suggestions can be traced back to Flaubert they will probably furnish evidences of relationship between the two. ${ }^{16}$ We must not forget, on the other hand, that Flaubert, according to his disciple, warned the latter against imitation, and that Maupassant passed on the warning. ${ }^{17}$ Similarities will, therefore, probably result rather from the unconscious reproduction of unforgettable memories than from conscious copying. ${ }^{18}$ Their occurrence will be rendered all the more likely by the fact that both men are engaged with subjects of somewhat similar nature, and that the younger has an unbounded admiration for the older. ${ }^{10}$

The two authors make definite statements regarding similar theories, beliefs, and likes or dislikes. In the case of Flaubert these are contained for the most part in his letters, with occasional references in his other writings. With Maupassant such personal expressions are found distributed more or less throughout his works. A general outline will now be given of the theories held in common by the two, in so far as we can gain a knowledge of these from their own utterances. Sometimes we have, in addition to the individual statements of each, Maupassant's report of Flaubert's doctrine. Any new point thus brought out will be noted. We shall also endeavor to observe as we go along how far they carry out in their works the theories which we may, from definite pronouncement, discover them to hold in common.

To both Flaubert and Maupassant present reality is odious, ${ }^{20}$ the world is more or less of an illusion, ${ }^{21}$ and all things are subject to an inexorable fatality. ${ }^{22}$ It is the sordid, the commonplace, the disI $87 \mathrm{ff}$.

15 "L'Oeuvre de Guy de Maupassant," R.D.M. (November I, I893), pp.

16 For example, see below, pp. 63-65, 87, 90, 97, 100-101, 102-103.

17 P.e.J.: 《L.R.», pp. xxiii-xxiv; B.d.S.: Corr., pp. clii-cliii.

${ }^{18} \mathrm{Cf}$. Ferrère, l'Esthétique de Gustave Flaubert, p. $26 \mathrm{I}$.

${ }^{19}$ See above, pp. 8, 9.

${ }^{20}$ For example, Corr., II, I40; III, 85, I8I-82, 232-33; IV, 243; V. 382.

${ }^{21}$ For example, Corr., IV, 336; B.d.S.: Corr., p. cxlv; S.l'E., p. 45.

22 For example, Corr., V, 512; B.d.S.: Corr., p. cvi ; cf. ibid., pp. cx, cxii. 
agreeable, or the horrible, that is generally represented by them. Misery or degradation is the almost universal lot of their personages. Should happiness seem at times to flit within the grasp of some exceptionally fortunate man or woman, it is only that disenchantment and sadness all the deeper may result. The one great word which Charles Bovary is represented as uttering-“c'est la faute de la fatalité !"23 might be taken as the motto for their picture of life. Unhappy beings are trampled by the inexorable march of events, or are made to suffer for giving way to passions to which they can no more help yielding than they can avoid being born. Death, with its repulsive physical concomitants, is for man the end of all things ; the idea of immortality is but an invention of the presumptuous imagination. ${ }^{24}$ The general effect of such a presentation is painful; there results from it for both writers a keen sense of sadness and of individual isolation. ${ }^{25}$ Escape from actuality is sought through excursions, either in person or in thought, to far-off countries and times which possess the romantic glamor of distant enchantment. ${ }^{26}$ Thus their personages-Emma Bovary, Rosanette, Pierre Roland, André Mariolle, and others-long to fly from present reality to future possibility. ${ }^{27}$ General resemblance in "atmosphere" of gloom between the works of Flaubert and those of Maupassant must not, however, be considered as proving in itself the influence of one upon the other, as it may derive equally well from the spirit of the materialistic epoch in which both lived.

The next point in the argument for relationship is perhaps more important, because more distinctive, than a pessimistic outlook upon life. It is the insistence of both men on the universal "bêtise" of humanity -a "bêtise" pervading all ranks, from the superstitious and stolid peasants to the inert and ineffective "Anciens" of Carthage, or the inane representatives of modern French society encountered by

${ }^{23}$ M.B., p. 480.

${ }^{24}$ For example, O.d.J., I, 407; P.l.C.e.p.l.G., pp. 175-76; Corr., I, I68, 194, 232, 299; IV, 26-28; B.d.S.: Corr., p. cxliv; L.p.R., p. 7 ; L.V.E., pp. 69-75.

${ }^{25}$ For example, Corr., IV, 14, I52, 357; V, 275; B.d.S.: Corr., pp. cxxx, cxlv; S.l'E., pp. 128-29.

${ }^{26}$ For example, Corr., III, 85, I8I-82, 203, 232-33; IV, 29, 243; V, 382; S.l'E., pp. $92 \mathrm{ff}$. etc.

${ }^{27}$ M.B., pp. 271-72, etc. ; L'Ed.S., p. 459, etc.; P.e.J., p. 204; N.C., pp. 223-24, 
Maupassant in Southern France. ${ }^{28}$ Its special exponent is the respectable "bourgeois," who stands rather for an attitude of narrow complacency or dogmatism than for any particular class-Homais, with his pompous and ridiculous speeches; M. Patissot, with his mania for exercise; the government functionary, who plays his part in guiding "the chariot of state through the incessant perils of a stormy sea" ;29 the "honnêtes femmes," who despise their unfortunate sisters while being not one whit better than they. ${ }^{30}$ One particular form of "bêtise" exhibited by this "bourgeois" is that of seeking for decorations. Examples are furnished by Homais in Madame Bovary and M. Sacrement in Maupassant's nouvelle entitled Décoré. ${ }^{31}$ Another manifestation of stupidity is subservience to habit. Both authors hated monotony and the life of habit and strove in their restlessness to escape from it, especially, as we have seen, by traveling. ${ }^{32}$ This hatred they express in their works. The stupid Charles is a creature of habit, as are the dull employees of L'Héritage. ${ }^{33}$ Emma and Jeanne owe part, at least, of their unhappiness to the monotonous tenor of their daily existence. The unvarying life of the country, of the provincial town, of the bureaucratic or industrial community in Paris, is constantly portrayed, together with the deteriorating or exasperating effects of that life. ${ }^{34}$ Scornful hatred of the "bourgeois" and of man in general becomes with Flaubert and Maupassant an obsession, as is evidenced by the following quotations:

\section{FlauberT}

L'insupportabilité de la sottise humaine est devenue chez moi une maladie, et le mot est faible. Presque tous les humains ont le don

\section{Maupassant}

Il flotte dans Paris tant de bêtises venues de tous les coins du monde, qu'on en éprouve comme un accablement [B.d.S.: Corr., p. cviii].

28 For example, P.l.C.e.p.l.G., p. 108; M.B., p. 40; M. Par.: Le Baptême, pp. 135-44; Sal., p. 120, etc.; S.l'E., pp. 24 ff.

29 M.B., p. 197.

${ }^{30}$ For example, M.B., pp. II0-12, 180, etc.; O.P., II: Les Dimanches d'un bourgeois de Paris, pp. 7, I I-14, etc.; M.B., pp. 197 ff.; M.Har.: L'Héritage, pp. 4I-I63; M.B., pp. 422-23; B.d.S., pp. 60-77.

31 M.B., pp. 477-78, 48I ; L.S.R., pp. 243-53. 32 See above, p. 12.

33 For example, M.B., p. 61 ; M.Har., pp. 41-163.

${ }^{34}$ For example, M.B., pp. 31, 62, etc.; T.C.: U.C.S., pp. 5-6, etc.; B.e.P., p. 13 ; L.M.T.: En Famille, pp. 139-4I ; L.S.R.: Suicides, pp. 232-33; Yvette: Promenade, pp. 20I-4; C.d.J.e.d.l.N.: Le Père, p. 38 ; M.Par., pp. 49 ff. ; L'I.B.: L'Epreuve, pp. 137-44. 
de m'exaspérer, et je ne respire librement que dans le désert [Corr., IV, 4II].35
Je vois des choses, farces, farces, farces, et d'autres qui sont tristes, tristes, tristes; en somme, tout le monde est bête, bête, bête, ici comme ailleurs [B.d.S.: Corr., p. cxxii].

Such an attitude of exasperation as that evidenced by the foregoing paragraphs seems to us excessive. It explains, however, the cynical tone which characterizes the work of the two men. How far, we are led to ask, was this exasperation and the resulting cynicism an inheritance from the older man in the case of the younger, and how far was it an inherent idiosyncrasy? In the first of the foregoing quotations from Maupassant and in other passages of his letters to Flaubert ${ }^{36}$ there is a suggestion that the expressions are dictated by the fact that the disciple is writing to the master. The second paragraph from the younger man produces, however, a greater impression of sincerity and can be supported by further evidence in the same direction. We may at least say this, that, if Maupassant had a natural bent toward scorn of humanity, as seems unquestionable, it was certainly not diminished through his intercourse with Flaubert. Human "bêtise" was specially emphasized by the latter, as his disciple tells us, in Bouvard et Pécuchet. ${ }^{37}$ Both men hold that the only hope for anyone who would maintain his individuality is to keep himself entirely separate from ordinary humanity. ${ }^{38}$ Among the supreme follies of the day, thinks each, is democratic government, with all its implications. $^{39}$ Modern tyranny is "bête," to be sure, but some form of aristocracy is at any rate preferable to democracy. ${ }^{40}$ In modern life "grace" or pardon is substituted for justice, Flaubert laying the blame for this on Christianity, Maupassant on romanticism. ${ }^{41}$ War is an evidence of the ineradicable brutality and unreason of the

35 Cf. also on "bêtise" and scorn of humanity, Corr., I, 43; II, 2, 43, 44, 69, 70, 103, 126, 179, 184-85, 196, 222-23, 282, 299, 308, 326, 445; III, 25, I1 2, 262; IV, 203, 367, 422; V, 274; etc.

${ }^{36}$ For example, B.d.S.: Corr., pp. xcix, ciii, cxiv, etc.

37 O.P., II: Etude sur Gustave Flaubert, pp. 104, $106 \mathrm{ff} ., 137$.

${ }^{38}$ Corr., IV, 80 ; B.d.S.: Corr., pp. cl-cli ; cf. S.l'E., pp. IIo-II.

${ }^{39}$ Corr., IV, 34, 60; B.d.S.: Corr., p. civ.

${ }^{40}$ Corr., I, I96; IV, 6I ; L.V.E., pp. 2-3, 6-9, 36-39, etc.

${ }^{41}$ Corr., IV, 80 ; cł. IV, 60 ; B.d.S.: Les Soirées de Médan, p. 82. 
human race. ${ }^{42}$ The barbarities of warfare are exhibited both through the cruelties practised by Carthaginians and mercenaries in Salammbo, and through the atrocities perpetrated by the Prussians and wreaked on them by way of vengeance in the stories of Maupassant. ${ }^{43}$

To the two men religion, which each admits to be universally present in one form or another, ${ }^{44}$ furnishes but additional illustrations of betise and hatefulness. What more stupid than man's affirmations and negations regarding the supernatural ? ${ }^{45}$ What more detestable than existing ecclesiasticism ${ }^{46}$ In its essence religion is either a superstition, a habit, or a romantic extravagance, and is connected not infrequently with sensual indulgence. The peasant is the principal exponent of superstition in both writers, examples being found wherever religion is mentioned in connection with peasant life. Félicité confusing her parrot with the Holy Spirit" and the "fille de ferme" attributing superhuman powers of insight to her curés $e^{48}$ are typical of their class. Religion as a habit is exhibited in the taking for granted by all ranks of the religious ceremonies attendant on the different stages of life. Even by the indifferent or the hostile it is considered but natural that the Church should preside over the initial stages of life, over marriage and death, and should dignify with her blessing the ordinary occupations of man on land or sea. ${ }^{49}$ Religion as romantic extravagance is illustrated in the cases of Emma Bovary and of Jeanne in Une Vie, both of whom experience violent paroxysms of religious fervor produced by circumstances and fostered by romantic sentiments. ${ }^{50}$ Emma serves further as an example of the connecting of religion with sensuality, ${ }^{51}$ in which she resembles Julien, Jeanne's husband, and similar characters of Maupassant's. ${ }^{52}$

42 Corr., IV, 48-49; S.l'E., pp. 51-59.

43 Sal., for example, pp. I28-35, etc.; for example, Mlle. F., pp. 3-27; C.d.l.Béc.: La Folle, pp. 37-43.

44 Corr., II, 151, 202, 232; C.d.J.e.d.l.N.: Le Gueux, pp. 178-79.

${ }^{45}$ Corr., IV, 35I, 385, etc.; S.l'E., pp. 39-40.

46 Corr., IV, 38, 353, 371, 377 ; B.d.S., pp. 7, 30, 62; etc.

${ }^{47}$ T.C.: U.C.s., pp. 53-54. $\quad 48$ L.MT.: Histoire d'une fille de ferme, p. 66.

${ }^{49}$ For example, M.B., pp. 9, 37, 125, 464-67; T.C.: U.C.S, pp. 61-64; B.e.P., pp. 297, 314-16; U.V., pp. 58-6r, 75-76, 196; B.-A., pp. 273 ff., 561-73.

${ }^{50}$ For example, $M . B$., pp. 49, 52, 295-98; U.V., pp. 263, 265-66.

51 M.B., pp. 298, $446 . \quad 52 U . V$., p. 266 ; cf. also $B .-A$., pp. 551-52, etc. 
Priests and other representatives of the church are made by each writer stupid, commonplace, or hateful. ${ }^{53}$ Attacks on ordinary religious beliefs and statements of "philosophical" religion are put into the mouths of Homais, of "le baron," of Moiron, of Renardet, and of many other characters in the works of both men. ${ }^{54}$

Neither author holds any very high conception of womankind. Each speaks of woman as incomprehensible, unreasonable, perfidious. ${ }^{55}$ They agree that there is little variety in feminine character. ${ }^{56}$ Maupassant says that Flaubert was disdainful of women, judging them severely from a distance, but exhibiting a certain tenderness toward them when brought into closer relationship. ${ }^{57}$ The older man himself expresses a somewhat similar thought where he speaks of the "souverain mépris" with which women are regarded essentially, while being treated outwardly with deference. ${ }^{58}$ As one would expect, the usual presentation of women, love, and marriage given by the two writers is cynical, with practical elimination of the ideal. If, by chance, we find a good woman like Mme Arnoux or Jeanne, ${ }^{59}$ she is almost certain to be either commonplace or stupid. Occasionally, indeed, we have glimpses, if not of the ideal, at least of a less sordid and unpleasing conception. Examples are the childish devotion of Justin to Emma in Madame Bovary ${ }^{60}$ the faithfulness of such simple creatures as Félicité in Un Coeur simple or Rosalie in Une $\mathrm{Vie}^{,{ }^{61}}$ and the constant affection of the woman in Corsica who had given up everything for the man she loved and expressed herself as perfectly satisfied after fifty years of the hard life to which she had

${ }^{53}$ For example, cf. L'abbé Bournisien in M.B., pp. 155-59, etc.; l'abbé Picot and l'abbé Tolbiac in U.V., pp. $177,182,234,263-64$, etc.; the "bonnes soeurs" of B.d.S., pp. 62-64, 73, 74, 76 .

${ }^{54}$ For example, $M$. B., pp. 106-7, 454-55, etc.; B.e.P., pp. 318 ff.; U.V., p. 267 ; C.d.L.: Moiron, pp. 20I-3; L.p.R., pp. 49-50; L'I.B., pp. 25 ff.

${ }^{55}$ For example, P.l.C.e.p.l.G., p. 299; Corr., III, 334; IV, 13; II, 129-30; I, 209; II, 6; C.d.J.e.d.l.N., p. 25; C.d.L., p. 216; M.Par. pp. 44, 45-46; L.R.d.M.H., p. 80 ; M.Par., p. 40; C.d.L., p. 93 ; Mlle. F., p. 73; etc.

${ }^{56}$ Corr., IV, 385 ; Mlle F.: Réponse à M.F.S., pp. 278-79; cf. C.d.J.e.d.l.N.: La Parure, pp. 59-60.

57 O.P., II, 9I, I44.

58 Corr., II, 122.

${ }^{59} L^{\prime} E d$. S.; $U . V$.

${ }^{60} M . B$., for example, pp. 299, 469.

${ }^{61}$ For example, U.C.S., p. 42 ; U.V., pp. 318-23. 
devoted herself. ${ }^{62}$ Such presentations are, however, the exception; the general picture is pessimistic in the extreme.

An idea mentioned by the two men-in the case of Maupassant apparently, from the reference, as a reflection from Flaubert-is that of the hatred of literature entertained by governments, ${ }^{63}$ an echo of the romantic doctrine of the literary man's martryrdom, expressed, for instance, by De Vigny. Suffering for the sake of art confers, of course, a certain distinction, and raises those who endure it far above such banalities as official decorations, for which both men, as we should expect, feel contempt. ${ }^{64}$

In striking contrast with their hatred of man is the very definite love they cherish for external nature. This is thus expressed by Flaubert in writing to Alfred Le Poittevin: "Tu me dis que tu deviens de plus en plus amoureux de la nature, moi, j'en deviens effréné. Je regarde quelquefois les animaux et même les arbres avec une tendresse qui va jusqu'à la sympathie; j'éprouve presque des sensations voluptueuses rien qu'à voir, mais quand je vois bien." Similarly Maupassant speaks of "certaines minutes d'amour avec la Terre, le souvenir d'une sensation délicieuse et rapide, comme de la caresse d'un paysage. ..." ${ }^{68}$ As one would then expect, fine descriptions of nature are among the most common and most characteristic features of the writings of both. Examples are universally present.

As we saw at the beginning of the chapter, the environment of Flaubert and Maupassant tended to give them a pessimistic outlook, which expresses itself in their contempt for the world and for man, especially for the "bourgeois." Government, religion, womankind, all come under their scorn. In the midst of the general stupidity the literary man is a martyr for his cause. On the contrary, love of external nature furnishes to each the satisfaction which he does not find in man.

${ }^{62}$ C.d.J.e.d.l.N.: Le Bonheur, pp. 8I-87. Maupassant subsequently spoils this story, where, repeating it in Sur l'Eau, he makes the woman commit suicide upon discovering the unfaithfulness of her husband. Cf. Mahn's remark on this story, p. 282 of his volume on Maupassant.

${ }^{63}$ Corr., IV, 42I, 430; V, 412 ; B.d.S.: Corr., p. cxvi.

${ }^{64}$ Corr., IV, 350, 363; B.d.S.: Corr., pp. cliii-clv.

${ }^{65}$ Corr., I, 163-64.

${ }^{66}$ M.Par.: A Vendre, p. 95. 


\section{CHAPTER III}

\section{DISCUSSION AND EXEMPLIFICATION OF DEFINITELY STATED THEORIES REGARDING LITERARY PROCEDURE}

In studying the similar literary theories of Flaubert and Maupassant we shall take account, as in the treatment of their general outlook upon life, not only of what each says regarding his own doctrines, but also of what Maupassant records concerning the tenets of Flaubert, as well as of the carrying out in practice of the theories stated.

In the mind of both writers impersonality is a fundamental necessity in the work of an author. ${ }^{1}$ LMaupassant calls Flaubert's impersonality "impassible" rather than impersonal." Flaubert uses, and Maupassant reports his use of, the figure of a mirror applied to the artist representing truth.

Flaubert

Soyons des miroirs grossissants de la vérité externe [Corr., II, 394].

\section{Maupassant}

... l'auteur ... devait être le miroir des faits, mais un miroir qui les reproduisait en leur donnant ce reflet inexprimable, ce je ne sais quoi de presque divin qui est l'art [O.P., Vol. II, E.s. G.F., p. 96].

It will be observed that the "mirror" here is not a mere reflecting mirror but one which transforms what it reflects. This, as it differentiates, is important for what immediately follows.

Impersonality, both writers confess, is hard to maintain. ${ }^{3}$ The exhibition of personal love or hate Flaubert regards as inadmissible, but considers that an author can never have too much "sympathy"by which he seems to mean the ability to interest himself in anything

${ }^{1}$ Corr., II, 182, 389, 394; III, II2-I3; IV, I64, 244-45; Mlle. F.: Réponse à M.F.S., p. 274 ; P.e.J.: «L.R.», p. xii.

2 O.P., II : Etude sur Gustave Flaubert, p. 96.

${ }^{3}$ Corr., II, I12-13; I, 213; III, 50r ; IV, 244-45; P.e.J.: \&L.R.», pp. xi-xii, xviii, xix-xx. 
and everything. ${ }^{4}$ Maupassant gives a clearer definition of impersonality and also a more general statement regarding the appearance of an author in his work. He recognizes that such appearance is inevitable, seeing that any man's view of the world, if it be original, must be derived from personal observation and reflection. Thus also in the case of the characters in a book. The author can but imagine how he would feel and act in their place, and in picturing them he in a sense reproduces himself. Impersonality is then to Maupassant not the absence of an author from his work-that is impossible-but the artistic concealment of the author's inescapable presence in his work. ${ }^{5}$ Flaubert had expressed the same conclusion when he said: "L'auteur dans son oeuvre doit être comme Dieu dans l'univers, présent partout et visible nulle part" ; but he had not worked out the argument as Maupassant has worked it out. In actual practice both authors adhere to impersonality to a certain extent, but only to a certain extent. Flaubert is on the whole impersonal in Madame Bovary and in $L^{\prime}$ Education sentimentale. It is difficult there to tell what his own opinion is regarding the majority of the personages and events. When we come to Bouvard et Pécuchet, however, the treatment is too ironical to be impersonal, there is too evidently a set purpose in the constant ridiculous inefficiency of the two "bonshommes." In the effort after impersonality there is also a tendency to overshoot the mark and arrive at impassibility, shown in what strikes one as the heartless recitation of the abnormal cruelties in Salammbô. ${ }^{7}$ Sometimes Flaubert departs from impersonality in the other direction, exhibiting a decided sympathy for his characters. This is true in certain of his pictures of humble, usually peasant life, as, for example, in the case of "le père Roualt," of Justin, of the old servant of the "Comices" in Madame Bovary, as well as of Félicité in Un Coeur simple. ${ }^{8}$ Maupassant, who sees, as was noted, ${ }^{9}$ the difficulty of impersonality more clearly than Flaubert, also forsakes the impersonal attitude more usually and often more completely than does his master. Some of his work, like Flaubert's, is impersonal on the

${ }^{4}$ Corr., III, 524.

5 P.e.J.: «L.R.», pp. xi-xx.

${ }^{8}$ For example, M.B., pp. 4I-42, 237-238, 46I, 462-63, 299, 469, 208-9; T.C., pp. 3-64.

9 See above.

${ }^{6}$ Corr., II, 182.

7 For example, pp. 185, 215, 348-50. 
whole; for example, stories like Bel-Ami, La Parure, L'Héritage, ${ }^{10}$ and those tales of peasant and fisher life which seem to embody the stolid acceptance of fact characteristic of the classes they represent. ${ }^{11}$ Many stories, such as the earliest, Boule de Suif, written possibly with the Bouvard et Pécuchet attitude toward humanity prominently in mind, are, like the similar efforts of Flaubert, too ironical to be impersonal. Sometimes Flaubert's irony is humorous, ${ }^{12}$ as where he makes people say ridiculous things; here Maupassant goes further than Flaubert, occasionally eliminating, or almost eliminating, the irony and leaving the humor in the ascendant. ${ }^{13}$ Brutally impassible also Maupassant can be in his depiction of horrible things. Examples are nouvelles like L'Ivrogne and Une Vendetta. ${ }^{14}$ On the other hand he possesses to no small extent the gift of exciting sympathy by the simple narration of the facts of real life ${ }^{15}$ This is especially true in connection with his stories of ill-treated animals and children, and of those unfortunates whose crimes or distresses, as he pictures them, have apparently been forced upon them by a pitiless society. ${ }^{16}$ In his later writings Maupassant tends more and more to give up the impersonal attitude and to express, either directly or through the mouths of his characters, his sympathy for various forms of suffering, ${ }^{17}$ or the record of his own distresses. ${ }^{18}$ All through their work both authors do in fact transgress the bounds of impersonality either by direct comment ${ }^{19}$ or by putting into the mouths of their characters the expres-

${ }^{10}$ C.d.J.e.d.l.N., pp. 59-74; M.Har., pp. 41-163.

${ }^{11}$ For example, L.S.R.: Le petit Fût, pp. 79-89; C.d.J.e.d.l.N.: Le Vieux, pp. 91-104; C.d.l.Béc.: En Mer, pp. 129-39.

12 For example, M.B., p. 180 (speech of Homais).

13 For example, Toine.

${ }^{14}$ C.d.J.e.d.l.N., pp. 125-34, 137-45.

${ }^{15} \mathrm{Cf}$. Lombroso, Souvenirs sur Maupassant, p. I62.

16 For example, M.Har.: L'Ane, pp. 189-94; C.d.J.e.d.l.N.: Coco, pp. I5056; L.M.T.: Le Papa de Simon, pp. I19-34; C.d.J.e.d.l.N.: Le Gueux, pp. 173-82; L.M.G.: Le Port, Part II, pp. 207-17.

${ }^{17}$ For example, $M .-O$., pp. 323-26; N.C., pp. 200-205, 224-25, 233-37, etc.

${ }^{18}$ For example, S.l'E., pp. 77-92.

${ }^{19}$ For example, M.B., pp. 92, I48, 390; L'Ed.S., pp. 47, 261-62, 266, 383, 407 ; P.e.J., pp. 59, 178; B.d.S., pp. 10, 30; U.V., pp. 34, 69, 75, 100, 123, 212, 248,330 ; etc. In comparison with most writers Flaubert has very little of this intervention of the author in person. 
sion of thoughts which the latter could not naturally have. ${ }^{20}$ Maupassant also frequently talks in the first person where such procedure is evidently not a mere realistic detail. ${ }^{21}$ It is further true, as has been pointed out by critics, ${ }^{22}$ that both men embody in their works their own lives and surroundings, as seems indeed to be inevitable when personal observation is insisted on as the main source of information.

The two authors hold that the great task of the novelist is to reproduce nature "truthfully." ${ }^{23}$ Maupassant thinks that Flaubert's novels accomplish this, for they exhibit "la vie même apparue." They agree also as to the meaning here of "truthfully." The faithful representation of nature denotes not the servile transcription of facts but rather the "translation" of those facts in terms of probability, through the subordination of the less to the more important, and through the selection of the universal and constant to the exclusion of the accidental and ephemeral. ${ }^{25}$ Maupassant thus describes, for instance, Flaubert's construction of character. The latter, he says, imagined types and, proceeding by deduction, made them perform acts characteristic of their temperaments. ${ }^{26}$ One must acknowledge that it is a rather narrow "nature" which the two men picture. It is admitted, however, by those who discuss the matter that the presentation is faithful in its way. For instance, Flaubert is said to be too true for the theatre ${ }^{27}$; while Brunetière declares regarding Maupassant that the latter renders even that which one has not noticed in the real. ${ }^{28}$ As far as one's personal knowledge or experience goes, it would seem to confirm the verdict of the critics. Again and again one is struck by the absolute agreement of the picture with what one knows or can imagine of the

20 For example, M.B., p. 475. $\quad{ }^{21}$ For example, S.l'E.

22 For example, P. Bourget, Essais de psychologie contemporaine, I, 148, 156; Dumesnil, Flaubert et la Médecine, p. 277.

${ }^{23}$ Corr., II, 213-14; III, 486-87; B.d.S.: L.s.d.M., p. 84.

24 O.P., II: Etude sur Gustave Flaubert, p. 96.

${ }_{25}$ Corr., III, 183, 449; IV, 245, 375; II, I12-13; III, 129, 193; P.e.J.: «L.R.», pp. xiii-xiv, xv, xii; Mlle F.: R. à M.A. Wolf, p. 282; Mlle F.: R. à M.F.S., p. 277.

${ }^{26}$ O.P., II : E.s.G.F., p. 99.

${ }^{27}$ R. Descharmes et R. Dumesnil, Autour de Flaubert, I, 242-43.

${ }^{28}$ F. Brunetière, "Trois Romans," R.D.M. (March I, 1887), pp. 202-I4. 
actuality represented. The methods of producing the effect of reality will be discussed in subsequent paragraphs.

In order to acquire the knowledge requisite for a truthful reproduction of nature keen observation is the first necessity. It is also the indispensable condition of originality. Maupassant says that Flaubert enjoined upon him the practice of looking long enough at what he desired to represent to discover in it an aspect which had not been seen nor recorded by anyone before him..$^{29}$ Very similar passages on this subject are found in the two authors.

FLAUbert

Flaubert is writing to Mme de Maupassant of her son:

"Avec le temps il gagnera de l'originalité, une manière individuelle de voir et de sentir (car tout est là) ... [Corr., IV, I60].

\section{Maupassant}

"Le talent provient de loriginalité, qui est une manière spéciale de penser, de voir, de comprendre et de juger" [P.e.J.: «L.R.,» p. viii]. Flaubert's "de voir et de sentir" is expanded in Maupassant.

A second passage contains another phrase of Flaubert's, "Voir*: tout est là et voir juste." ${ }^{30}$

To Flaubert seeing is "absorbing" the object. In connection with the composition of Un Coeur simple he writes: "Depuis un mois j'ai sur ma table un perroquet empaillé afin de «peindre» d'après la nature. Sa présence commence à me fatiguer. N'importe! je le garde afin de m'emplir l'âme de perroquet." ${ }^{31}$

Maupassant thus reports Flaubert's advice to him:

Quand vous passez, me disait-il, devant un épicier assis sur sa porte, devant un concierge qui fume sa pipe, devant une station de fiacres, 1 montrez-moi cet épicier et ce concierge, leur pose, toute leur apparence physique contenant aussi, indiquée par l'adresse de l'image, toute leur nature morale, de façon à ce que je ne les confonde avec aucun autre épicier ou avec aucun autre concierge, et faites-moi voir, par un seul mot, en quoi un cheval de fiacre ne ressemble pas aux cinquante autres qui le suivent et le précèdent. ${ }^{32}$

In the passage from Flaubert we have simply a slightly ironic description of one application of the method of "seeing." In that from Maupassant we have a description not only of the method of "seeing" but also of its results-the definite impression produced

${ }^{29}$ P.e.J.: $\ll L . R . »$, pp. xxiii-iv.

30.B.d.S.: Corr., p. cli.
31 Corr., IV, 268.

32 P.e.J.: «L.R., p. xxiv. 
and the rendering of the impression in few and skilful words. The same quotation will be seen to develop the idea of the "characteristic detail." Such observation as has been indicated involves, of course, precise attention to all detail, but especially to the "characteristic detail," on which Maupassant insists. The advice to find out and render this "characteristic detail" seems at first sight to contradict the other counsel to avoid the accidental and picture only the constant. The "characteristic detail," however, is not accidental; it is inherent by nature in the object described; it has only not yet been discovered or presented. Flaubert himself explains what he means by the accidental in the following passage: "Je me suis toujours efforcé d'aller dans l'âme des choses et de m'arrêter aux généralités les plius grandes, et je me suis détourné exprès de l'accidental et du dramatique. Pas de monstres et pas de héros!"33 The object represented is to be an average object; the originality of the author is to consist in exhibiting a hitherto unknown aspect of the average object which has become, to him, characteristic of it. To illustrate-both Flaubert and Maupassant would have described one particular red carnation in order to distinguish it from all other red carnations, but would probably have avoided the description of a green carnation.

On observing the actual practice of the two men we find that the "characteristic detail" is, in general, introduced less strikingly in the work of Flaubert than in that of Maupassant. Its functions in either case are various. By Flaubert it is sometimes used to unify a description, all other details being made subordinate to it. For instance, at the beginning of the third chapter of Salammbô, Carthage is depicted according to the lights and shadows caused by the moonlight falling upon it. ${ }^{34}$ Often, however, in this writer, the multitude of minor details introduced in the effort after completeness blurs the impression, so that it is difficult to distinguish a "characteristic detail" if such is present. ${ }^{35}$ In Maupassant, on the other hand, owing to the constant use of the "characteristic detail," outlines are sharp; descriptions are easily grasped and, once grasped, may usually be summarized in one or two words and remembered without difficulty. Good examples may be found in almost any of

$$
{ }^{33} \text { Corr., IV, 245. } \quad{ }_{34} \text { Sal., pp. 55-56. }
$$

${ }^{35}$ For example, M.B., pp. 130-31. Is the river the "characteristic detail" of the scene here? 
his works. ${ }^{36}$ The "characteristic detail" is emphasized by both men, again by Maupassant more distinctly and more often than by Flaubert, through recurring mention. An example is the repeated reference, in Flaubert to the awkward and common personal appearance of Charles Bovary, which seems to symbolize that man's stupidity, ${ }^{37}$ and in Maupassant to the elegance of Julien, which furnishes an indication, according as it waxes or wanes, of the state of the latter's amorous affairs. ${ }^{38}$ Other examples from Flaubert are the insistence on the lack of energy of Frédéric Moreau in L'Education sentimentale, the designation of the mercenaries in Hannibal's garden each by a distinctive trait, and the use of the "characteristic detail" as a conclusion in the case of Salammbô's veil floating behind her when she is seen in the chariot. ${ }^{39}$ Corresponding instances from Maupassant are the dwelling on Forestier's ill-health and Mme Forestier's smile in Bel-Ami, the characterizing one by one of the travelers in the diligence of Boule de Suif, and the concluding of the story entitled Le Père with a sentence giving the outstanding aspect of the conduct of the "father."

In order to accomplish distinctive as well as accurate presentation both Flaubert and Maupassant seek to avoid hackneyed expressions. A certain use of "idées reçues" is made, however, in Flaubert and more occasionally in Maupassant in the conversations of personages to whom it is desired to give the characteristic of "bêtise." Good examples are to be found throughout Bouvard et. Pécuchet and in the remarks of Homais, the Abbe Bournisien, etc., in Madame Bovary. ${ }^{41}$ In Maupassant instances are to be sought among ecclesiastical pronouncements, such as the address of the cure in La Maison Tellier, or in the conversation of "gens du monde," like that between the two women in the stagecoach towards the end of Boule de Suif. ${ }^{42}$

36 For example, the representation of the characters in Une Vie, pp. 3-46, 8-9, 30-34, 35, etc.

${ }^{37} M . B .$, pp. $2,59,76,85, \mathrm{I} 4 \mathrm{I}$, etc.

38 U.V., pp. 39, 57, 126, I31, I88, etc.

${ }^{39}$ L'Ed.S., pp. I2, 30, 32, 34-35, 92-93, I10, etc.; Sal., pp. 3 and 25.

${ }^{40} B .-A$., pp. 8-9, I20, I27, I91, etc. ; 31, 33, 46, 64, 99, I19, 120, 126, etc. ; B.d.S., pp. 14-20; C.d.J.e.d.l.N., p. 44.

${ }^{41}$ For example, B.e.P., pp. 4, 5, 8, II, 17, 24, etc.; M.B., pp. 102-7, 156-59, etc.

42 L.M.T., pp. 37-38; U.V., p. 234 ; B.d.S., p. 73 ; U.V., p. 136. 
Corresponding to the "characteristic detail" in description and necessary for its delimitation is the "mot juste" in language. Flaubert had said that it was time to give to art the precision of the physical sciences. ${ }^{43}$ Maupassant had maintained that art was mathematical, and that great effects were to be obtained by simple and well-combined means. ${ }^{44}$ The "mot juste" is among the most important of these means. Both men dwell on the subject, Maupassant relating how Flaubert insisted upon precise expression. ${ }^{45}$ With the master the "mot juste" is usually connected with his idea of the inevitable correspondence between sound and sense; with the pupil the emphasis is rather on the actual justesse of the mot. The following quotations will illustrate what is meant.

Flaubert says :

Ce souci de la beauté extérieure que vous me reprochez est pour moi une méthode.* Quand je découvre une mauvaise assonance ou une répétition dans une de mes phrases, je suis sûr que je patauge dans le faux; à force de chercher, je trouve l'expression juste qui était la seule et qui est, en même temps, l'harmonieuse. ${ }^{46}$

Flaubert, then, finds the mot juste with the aid of the harmonious word.

Maupassant, reporting Flaubert's advice to him, speaks as follows :

Obsédé par cette croyance absolue qu'il n'existe qu'une manière d'exprimer une chose, un mot pour la dire, un adjectif pour la qualifier et un verbe pour l'animer, il se livrait à un labeur surhumain pour découvrir, à chaque phrase, ce mot, cette épithète et ce verbe. Il croyait ainsi à une harmonie mystérieuse des expressions, et quand un terme juste ne lui semblait point euphonique, il en cherchait un autre avec une invincible patience, certain qu'il ne tenait pas le vrai, l'unique.47

We find in these words the mot juste defined as "a noun, an adjective, or a verb." Otherwise the passage simply states again the theory of Flaubert quoted in the preceding paragraph.

In another passage, after speaking of Flaubert, Maupassant goes on with his special definition of the mot juste as "a noun, an adjective, or a verb." $\mathrm{He}$ then continues: "Il faut donc chercher,
${ }^{43}$ Corr., III, II3.
46 Corr., IV, 25 I.
44 B.d.S.: Corr., p. clii.
${ }^{47}$ O.P., II: E.s.G.F., p. 130.
${ }^{45}$ For example, P.e.J.: «L.R., pp. xxiv-xxv. 
jusqu' à ce qu'on les ait découverts, ce mot, ce verbé et cet adjectif, et ne jamais se,contenter de l'à peu près, ne jamais avoir recours $\grave{a}$ des supercheries, même heureuses, $\grave{a}$ des clowneries de langage pour éviter la difficulté." 48 The mot juste is to be sought then, presumably, among the ordinary expressions of ordinary good usage. In this and the following paragraphs Maupassant is deprecating especially the employment of the "écriture artiste" (like that of the Goncourts and others supposedly). ${ }^{49}$ We find in the same place the additional idea that the relative position of a word must be taken into account in determining its exact meaning. He seems also towards the end of the passage, to advocate an attention to sound similar to that of Flaubert. "Ayons," he says, "moins de noms, de verbes et d'adjectifs aux sens presque insaisissables, mais plus de phrases différentes, diversement construites, ingénieusement coupées, pleines de sonorités et de rythmes savants." This sentence reminds one not a little of the older man's attitude, quoted on a preceding page.

In practice Maupassant here again, as in the case of the "characteristic detail," often makes a deeper impression than Flaubert because there is with him less softening down of the effect. Examples of the "mot juste" may be discovered on practically every page of both writers. Study of its nature reveals the fact that it is, generally speaking, as Maupassant has told us it will be, "a noun, a verb, or an adjective," more usually a verb or an adjective than a noun. It is also sometimes an adverb. It is often a word used in the ordinary sense, but when so it does not catch the attention, nor indeed can it be expected to do so under such circumstances. We are not particularly struck upon hearing a spade called a "spade," although "spade" is no doubt the "mot juste" for that instrument. The word which impresses us with its peculiar fitness for definition of a person, an object, or a situation is very frequently one used figuratively. Again the "mot juste" will at times be a phrase, where one word does not seem to meet the occasion. The effort after this "mot juste" results often in Maupassant, less frequently in Flaubert, in the employment of a succession of words, usually verbs or adjectives, aiming at the effect sought. Illustration of the "mot juste" is difficult because of the great abundance of examples. It seems necessary, however, because of the importance of the subject in the

${ }^{48}$ P.e.J.: $\ll L . R . »$ p. $\mathrm{xxv}$.

49 Ibid., pp. xxv-vi. 
doctrine of the two authors. An attempt will therefore be made to illustrate the "mot juste" by means of the following examples, chosen more or less at random. It has not been thought advisable to include instances of words used merely in their ordinary sense.

The mot juste in Flaubert as a single word:

"Elle entrait dans quelque chose de merveilleux où tout serait passion, extase, délire; une immensité bleuâtre l'entourait, les sommets du sentiment étincelaient sous sa pensée ..." [Said of Emma at the beginning of her intrigue with Rodolphe] (M.B., p. 225).

" ... tout autour de la péninsule carthaginoise une ceinture d'écume blanche oscillait." [Of the waves breaking on the shore.] (Sal., p. 21.)

"Des candélabres, brûlant sur les tables alignées dans toute la longueur du vaisseau, faisaient des buissons de feux, ..." (T.C.: Hérodias, p. I73).

"Emma, dès le vestibule, sentit tomber sur ses épaules, comme un linge humide, le froid du plâtre" (M.B., p. II 7 ).

"Le ciel, d'un bleu tendre, arrondi comme un dôme, s'appuyait à l'horizon sur la dentelure des bois" (L'Ed.S., p. 469).

"... le chagrin s'engouffrait dans son âme avec des hurlements doux, comme fait le vent d'hiver dans les châteaux abandonnés" (M.B., p. I7I).

"La conversation de Charles était plate comme un trottoir de rue, ..." (M.B., p. 57).

" ... puis venait une file de minces bouleaux, inclinés dans des attitudes élégiaques: ..." ( L’Ed.S., p. 466).

The mot juste in Maupassant as a single word:

"L'arsenal de l'esprit paysan fut vidé" (C.d.l. Béc.: Farce Normande, p. 9I).

"Un flot de soleil tombait sur la rivière endormie et luisante." [Of the Seine on a hot day.] (Yvette, p. 56.)

"La torche ... illuminait le grand rideau de sapins" (U.V., p. 210$).$

"Le platane et le tilleul se dévêtaient rapidement sous les rafales" (U.V., p. 124).

"Le long de la route, l'herbe, que ne couvrait point encore l'ombre impénétrable des cimes, étaite drue, luisante, vernie de sève nouvelle" (N.C., p. 230).

"Il était laid, noueux comme un tronc d'olivier." [Of Corsican bandit.] (Au S.: Les Bandits Corses, p. 207.)

On reading the words italicized above, one has the feeling that they are exactly the expressions required in the places where they occur. Some examples will now be given of phrases as "mots justes." 


\section{Flaubert :}

"Ainsi se tenait, devant ces bourgeois épanouis, ce demi-siècle de servitude." [This phrase is applied to the old servant of the "Comices" who receives a medal for fifty years of slavish service.] (M.B., p. 209.)

"Quand elle eut ainsi un peu battu le briquet sur son coeur sans en fair jaillir une étincelle,..." [Of Emma, trying to "give herself love."] (M.B., p. 6r.)

\section{Maupassant :}

"Dans cet apaisement du soleil absent, toutes les senteurs de la terre se répandaient." [The phrase in italics describes the peace of night.] (U.V., p. 18.)

"Une grosse femme, bâtie en forteresse, remplaçait Rosalie ..." (U.V., p. 186).

Besides striking combinations of words, such as are illustrated above, both Flaubert and Maupassant employ somewhat vague phrases which seem to contain rather an effort after the "mot juste" than the attainment of it. Examples are given below.

Flaubert :

"Quelque chose des vitalités planétaires le pénétrait. ..." [Said of Hannibal meditating in the "maison-amiral."] (Sal., p. I42.)

"C'était comme une montagne lumineuse, quelque chose de surhumain, écrasant tout de son opulence et de son orgueil." [Said of the Temple, seen by Herod from his citadel.] (T.C.: Hér., p. I4I.)

\section{Maupassant :}

“... sa voisine, ... portait en elle ce quelque chose de fripé, d’artificiel qu'ont, en général, les anciennes actrices, ..." (B.-A., p. 75).

Maupassant frequently uses "une sorte de" in such phrases, instead of "quelque chose de."

"Le murmure des voix montait, ... une sorte de poussière de bruit." [Of voices of crowd heard from some distance.] (M.-O., pp. 38-39).

The use of a succession of words in striving for the mot juste is much more common in Maupassant than in Flaubert, but is occasionally found also in the latter.

Flaubert

Elle entrait dans quelque chose de merveilleux où tout serait passion, extase, délire. [M.B., p. 225]
Maupassant

Il lui demandait conseil, pitié, secours, protection, consolation, ... [L'I.B., pp. 54-55]. 
We come now to consider the attitude of the two writers on the question of beauty in general effect apart from the specific details producing the result. This was the supreme concern of Flaubert. Form and idea were indeed, in his eyes, inextricably interdependent, but, of the two, form was the more important..$^{50}$ He seems to have imagined "style" as something abstracted from and superior to the content which it clothed. There was, however, in practice an unbreakable connection between sound and sense, between the mot euphonique and the mot juste. His final test for accuracy of expression was to read a passage aloud. If, thus read aloud, it did not satisfy his fastidious ear, he set to work to alter it. He says himself : "Les phrases mal écrites ne résistent pas à cette épreuve; elles oppressent la poitrine, gênent les battements du coeur, et se trouvent ainsi en dehors des conditions de la vie." ${ }^{51}$ All this shows Flaubert's. extreme care for the rhythm of his prose. From what he has said in other passages we gather the idea that style was to him that part of an author's work where the intangible something which we call "genius" would become apparent. "Dans la précision des assemblages, la rareté des éléments, le poli de la surface, l'harmonie de l'ensemble, n'y a-t-il pas une vertu intrinsèque, une espèce de force divine, quelque chose d'éternel comme un principe?" ${ }^{2}$ He even goes so far as to declare:

Ce qui me semble beau, ce que je voudrais faire, c'est un livre sur rien, un livre sans attache extérieure, qui se tiendrait de lui-même par la force interne de son style, comme la terre sans être soutenue se tient en l'air, un livre qui n'aurait presque pas de sujet ou du moins où le sujet serait presque invisible, si cela se peut. Les oeuvres les plus belles sont celles où il $\mathrm{y}$ a le moins de matière; plus l'expression se rappoche de la pensée, plus le mot colle dessus et disparait, plus c'est beau. ${ }^{53}$

Maupassant, reporting Flaubert, notes the fact that to the latter the form was the work itself, and form and content were interdependent. $^{54}$ He furnishes us besides with a description of Flaubert's process of reading aloud (to which the word "gueuler" is attached by those who mention it, Flaubert himself included).

Quelquefois ... il prenait la feuille de papier, l'élevait à la hauteur du regard, et s'appuyant sur un coude, déclamait d'une voix mordante

${ }^{50}$ Corr., I, 196, 244; II, 129, 426, 430, etc.; III, 113, 162, 268; IV, 246.

${ }^{51}$ Corr., IV, Appendix, p. 457. $\quad{ }^{53}$ Corr., II, 86.

${ }^{52}$ Corr., IV, 252-53. $\quad 54$ O.P., II : E.s.G.F., pp. 129-30. 
et haute. Il écoutait le rythme de sa prose, s'arrêtait comme pour saisir une sonorité fuyante, combinait les tons, éloignait les assonances, disposait les virgules avec science comme les haltes d'un long chemin. ${ }^{55}$

After having once discovered a harmonious phrase Flaubert found it, says Maupassant, impossible to change, even where such change would have been to the advantage of the sense. ${ }^{58}$ He quotes a long pronouncement of Flaubert's on the rare difficulty and dignity of rhythm in prose. ${ }^{57} \mathrm{He}$ gives also two definitions of what seems to him to be Flaubert's conception of style. In one place he says that style to Flaubert is not a mere matter of words but includes all the qualities of the thinker and writer. ${ }^{58}$ In another passage on the same page he distinguishes between "styles"-the separate manners of writing peculiar to separate individuals-and "style"-something which has almost a being of its own apart from content, and which does not vary from one author to another. It seems here to mean rather what we should call "the inspiration of genius" than anything else. The two definitions are not necessarily contradictory, but the latter seems to come nearer than the former to what we have seen to be Flaubert's own idea of "style."

Maupassant, when he comes to speak for himself, says that the true power of literature lies not so much in what is said as in the method of preparation and presentation. The expression must accord with the idea, such agreement possessing a certain beauty not perceptible by the crowd. ${ }^{59}$

As we turn now from theory to practice a general perusal of the works of the two men leads to the impression that their styles are, on the whole, not closely similar. One misses, for example, in the precision of the younger man the general romantic atmosphere of the typical Flaubertian passage. Neither does one usually find in Maupassant the striking phrases with rhythmical effect common especially in the earlier work of the older writer. Where one does find such phrases, contrary to custom, in Maupassant, one might be led to suspect an influence, especially where thought or wording or both are at all alike. The two following phrases suggest such a resemblance :
55 Ibid., p. 13I.
58 Ibid., p. 129.
56 Ibid., p. 132.
59 Ibid., p. 128.
57 Ibid., pp. 132-33. 
Flaubert

L'oblique génuflexion des dévots pressés $[M . B ., p .331]$.
MAUPASSANT

L'onde onctueuse des consolations ecclésiastiques [U.V., p. 233].

The rhythm of these two phrases is very similar, and the ideas are at least related.

In two other respects there is a resemblance between Flaubert and Maupassant in point of style. On the one hand, both attain to a considerable degree of "justesse" of tone as well as of word. As examples from Flaubert one might cite the generally poetic effect of La Légende de Saint Julien l'Hospitalier compared with the simplicity of Un Coeur simple. The same quality is very evident in practically all of Maupassant's stories of peasant life, as, for instance, in the laconic recital of the accident in En Mer, or in the familiar conversation of La Bête à Maît' Belhomme. ${ }^{80}$ On the other hand, there is frequently a disparity more or less distinctly felt between style and subject. In Flaubert we have, as in Madame Bovary, the opposition between romantic style and commonplace subject; in Maupassant we meet often the contrast between charming style and utterly disagreeable subject. Both men employ many similar technicalities of style; these will be taken up in later paragraphs. ${ }^{61}$

The two authors agree that there must be harmony between word and idea, not only in separate passages of a work but also throughout the whole work. Such unity is frequently attained through the ironical presentation of life, which results in large measure from the scorn of humanity entertained by either. Nothing escapes their irony ; all classes, all conditions, all situations, and all events touched by them come alike under the lash. In expressing itself this irony assumes various forms. Sometimes it manifests itself in circumstances. People are constantly being duped or disenchanted. Emma Bovary, for example, despises the one man who ever truly loves her and seems to be touched by some faint realization of her mistake only at the eleventh hour. ${ }^{62}$ Mme Loisel wears herself out in order to replace a necklace which turns out to have been of false

${ }^{60}$ C.d.l.Béc., pp. 129-39; M.Par., pp. 79-91.

${ }^{61}$ After Madame Bovary the style of Flaubert tends to lose its figurative quality, so that in his later works it approximates the dryness and simplicity of Maupassant's manner.

${ }_{62}$ M.B., pp. 437, 438. 
stones, and is informed of the fruitlessness of her labor only after she has lost forever youth, beauty, and happiness. ${ }^{63}$ Sometimes the ironical effect is increased by a process of cumulation, as in Boule de Suif, where the "respectable" characters appear one after another as knaves and hypocrites beside the woman they despise, or in Bouvard et Pécuchet, where Flaubert takes up successively the different departments of human thought, only to show the folly of all. The idea that thought is one of the worst things in life because it makes men wretched is expressed in so many words towards the beginning of this book, and occurs more than once in Maupassant. ${ }^{64}$ An illustration of its acceptance by both men is that they describe most sympathetically those characters least distinguished by thinking-the simple, animal-like peasants. In the pursuit of irony the characters are sometimes made to say ridiculous things; for instance, in the manner of Homais and the Homais-like personages in Maupassant. $^{65}$ Sometimes a remark by the author supplies the point of irony, as where Arnoux is said to seek "le sublime à bon marché," or where "mon oncle Sosthène" is described as "libre penseur par bêtise." sardonic humor-an attribute of authorship which Flaubert expresses himself as desirous of developing in order to accomplish the ironic picture after which he strives. Maupassant thinks that his master has attained this particularly in Bouvard et Pécuchet. The passages expressing these ideas are as follows:

Flaubert

Le comique arrivé à l'extrême, le comique qui ne vous fait pas rire, le cynisme dans la blague, est pour moi tout ce qui me fait le plus envie comme écrivain [Corr., II, I40].

\section{Maupassant}

Maupassant finds in Bouvard et Pécuchet "un comique tout partıculier, un comique sinistre" [O.P., II, I05].

Even in less apparently ironical humorous situations in Maupassant there is often a sting in the very extremity of the absurdity ${ }^{67}$

${ }^{63}$ C.d.J.e.d.l.N.: La Parure, pp. 69-74.

${ }^{64}$ For example, B.e.P., p. 13; L'I.B., pp. 30-3I ; B.-A., p. 21 I.

${ }^{65}$ For example, M.B., pp. III-12, etc.; C.d.L.: Un Coup d'état, pp. 3-3I, 32 , etc.

${ }^{66}$ L'Ed.S., p. 56; L.S.R.: M.O.S., p. 109.

${ }^{67}$ For example, Toine; Marius in Une Vie, pp. 132-33, 139; etc. 
Maupassant is at times frankly and gratuitously vulgar, ${ }^{68}$ or exhibits a coarseness which appears also in Flaubert, and from which he was at least not discouraged by the latter. ${ }^{69}$ In the later works of Maupassant and to a much smaller degree of Flaubert, as sympathy increases irony tends to disappear, although never perhaps entirely absent. $^{70}$

With regard to subjects, both men hold that any subject is admissible, but that the author should choose what is suited to his temperament. ${ }^{71}$ Flaubert concedes so much to temperament that he declares subjects are not chosen but impose themselves through its influence. Masterpieces may be written on any subject, even the most insignificant and vulgar. The author, seeing that he is to be controlled by his own temperament, must be free from the interference of external criticism. In these points Maupassant agrees with his master either explicitly or implicitly. Upon investigation we discover that the subjects actually selected by the two are for the most part "realistic"-the representation of middle-class mediocre humanity in the provinces or in Paris, of the peasant on his native soil, of the government functionary in the performance of his monotonous duties, of illicit love, of birth, marriage, and death. Even in the picturing of more "far-off" matters, as in Salammbô or in Maupassant's stories of fanciful beings or occurrences, ${ }^{72}$ the "realistic" method is used, such procedure and details being adopted in presentation as will give the impression of actual fact. What the method of development is will be discussed in the succeeding chapter of this thesis.

If all subjects are equally worthy, and if form is the supreme concern of art, it will follow that the artist will write for the sake of art alone. As a matter of fact, Flaubert held very strongly the theory of "art for art's sake," of the non-concern of art with morality or utility. Maupassant thus sums up his master's teaching on this matter: All great writers have protested against making their works didactic. Principles are indispensable to the social order, but letters and the social order have nothing in common. The chief concern

${ }^{68}$ For example, certain elements in the story of Toine

${ }^{69}$ For example, Sal., p. I53; S.l'E., p. 103.

${ }^{70}$ See above, pp. $21-24$.

${ }^{71}$ Corr., II, 82, 84-85, 86-87, 293; III, I47, 304, 542; IV, 255 ; P.e.J.: «L.R., pp. vii-viii, x; Mlle F.: R. $a$ M.F.S., pp. 275 ff.

72 For example, Le Horla, pp. 3-48. 
of novelists is to observe and describe human passions, good or bad. Their mission is not to moralize or instruct. Every book advocating a cause ceases thereby to be an artistic book. ${ }^{73}$

Finally both men were conscious of the fundamental need of prolonged and incessant work in order to attain success in writing. Both exemplified this belief in practice. Maupassant records the fact of Flaubert's unremitting labor $7^{74}$ we have noted above the latter's advice to the former on the necessity of work $;^{75}$ and the younger man himself must have undergone extreme toil in order to complete what we have from his pen within the space of his comparatively short literary career.

In considering the literary theories of Flaubert and Maupassant reference has been made only to such beliefs as the two hold in common. We have not attempted to give a complete statement of the doctrine of either. Yet what has been said includes the more important tenets of both. We have seen how, in some cases, Maupassant develops a particular aspect of a theory further than does Flaubert and perhaps passes lightly over what the latter emphasizes. A good example of this is to be found in the case of the mot juste, where, as we saw, Maupassant dwells upon the justesse of the mot, Flaubert rather upon its euphony. In general we may say that Maupassant's theory, with its insisting upon but one or two points, is less elaborately worked out than Flaubert's. In practice the theory of each expands or becomes more clearly differentiated. Impersonality, for instance, is found to present different aspects or different degrees of intensity, "nature" to have a certain specific meaning. On the whole the case for the influence of one man on the other is strengthened when theories which in their statement might have indicated merely repetition of the one by the other are observed to be effectively operative in both.

73 O.P., II, 97.

${ }^{74}$ Ibid., pp. 124, 130, 134-35.

${ }^{95}$ See above, p. 6. 


\section{CHAPTER IV}

\section{LIKENESS IN EMPLOYMENT OF GENERAL REALISTIC DEVICES}

Besides the literary devices of Flaubert and Maupassant already discussed, which result from the theories definitely stated by them, there are additional literary procedures employed by both which, for the most part, they share in common with the other realists of the day. In tracing the relationship between the two men it would not be wise to omit consideration of such procedures, for certain of them may come from the one to the other instead of being a common heritage. In any event, when taken along with less disputable cases of influence, the assemblage of them will possess a cumulative weight of proof for the relationship.

Many of these procédés, now to be considered, may be grouped together under the head of "realistic details." The first of these details is the practice of beginning in medias res, which is the usual procedure of both men in their novels and a frequent one of Maupas. sant's in his short stories. Closely akin to this is the ending with a kind of "broken-off" effect, leaving in the reader's mind the idea of an action still continuing, as in real life. So conclude Flaubert's Madame Bovary, L'Education sentimentale, and Hérodias, and Maupassant's Notre Coeur, Pierre et Jean and Bel-Ami, besides some of the latter's short stories. ${ }^{1}$

Definite time indications are exceedingly common in both authors. The year, the month, the day, the hour, of an event is often mentioned with extreme exactitude. In some stories one can date exactly or approximately almost every episode. Examples would be $U n$ Coeur simple and Une Vie. On the other hand there are narratives with little or no definite dating, like Flaubert's Saint Julien l'Hospitalier or Maupassant's Mont-Oriol. Dating is often from the age of a character or characters, ${ }^{2}$ or from a well-known and definitely fixed event-a historical fact, for instance, such as some political

${ }^{1}$ For example, in C.d.L., Un Coup d'état, Le Père, etc.

${ }^{2}$ See $U n$ Coeur simple and Une Vie, already mentioned, where some of the definite dating is done through mention of ages. 
occurrence. L'Education sentimentale furnishes many examples of this latter method, as do also Maupassant's stories of the FrancoPrussian War. ${ }^{3}$ Lapse of time is sometimes denoted in so many words, ${ }^{4}$ sometimes implied through the use of the imperfect tense or in the multitude of happenings. ${ }^{5}$ Occasionally it is suggested by the reappearance of some thing to which attention has been called before, and which has then been lost from view for a time. An example in Flaubert is the wedding bouquet of Madame Bovary, put aside by her on the evening of her arrival in Tostes, and discovered in a drawer when she is about to leave the place, after long-continued experience of disenchantment. ${ }^{6} \quad$ A similar instance in Maupassant is furnished by the calendar marking for Jeanne the day of her departure from school life to expected happiness in the future, which, found by her, with other calendars, in the attic, after long years of disappointment, is utilized in her effort to reconstruct the past. ${ }^{7}$ The actual mention of the time in both writers is often made in the most casual way, as befits the realistic method. "Un après-midi (c'était le 20 janvier 1839), Bouvard étant a son comptoir reçut une lettre, apportée par le facteur." "C'était en I827, au mois de juillet. Je me trouvais à Rouen en garnison." "

A special method of time indication, perhaps more distinctive of Flaubert and Maupassant than those already discussed, is that given by means of some happening denoting the season of the year. This is fairly frequent in Flaubert, and it is possible that Maupassant may have taken it from him. Well-known examples are the splashing of drops of melting snow on Emma's parasol, and the falling of the ripe peach from against the wall when Rodolphe and Emma are in the garden together. ${ }^{10} \mathrm{~A}$ frequent instance in Maupassant is the rather commonplace mention of falling leaves to suggest the autumn season. ${ }^{11}$ The "heavy heat" of summer is noted by both men. ${ }^{12}$ Some-

${ }^{3}$ For example, L'Ed.S., pp. 38 ff., 3 II, 409 ff., 456 ff., 475 ff.; Mlle F., pp. 3-27; Mlle F.: Deux Amis, pp. 209-21.

4 T.C.: U.C.S., p. 57 ; U.V., p. 288.

${ }^{5}$ For example, T.C.: S.J.l'H., pp. 82-89, etc.; M.-O., pp. I2I ff., etc.

${ }^{6} M . B .$, pp. 44-45, 94 .

${ }^{8}$ B.e.P., p. 14.

7 U.V., pp. 2, 367.

${ }^{9}$ C.d.L.: Apparition, p. 157.

${ }^{10}$ M.B., pp. 23, 275; cf. Brunetière, Le Roman naturaliste, pp. 181-83.

${ }^{11}$ For example, $U . V$, pp. 118-19; L.p.R., pp. 32-33; etc.

${ }^{12}$ For example, M.B., p. 284; L'Ed.S., pp. 466-67; U.V., p. 70; L.M.T.: En Famille, p. 137. 
times the time of day is indicated thus characteristically, as well as the time of year. Both men, for instance, call attention to another generally observed circumstance, the "peeping" or fluttering of the birds in the very early morning. ${ }^{13}$

A common method of giving vividness to a narration is that of "taking things for granted," explanation being omitted, as if one were dealing with a well-known object or current event. Flaubert has sometimes carried this practice so far that the result is a sense of vagueness, present, for instance, on reading many passages of Salammbo. ${ }^{14}$ When not pushed to excess, however, the procedure lends an effect of reality to a picture, the author, as it were, associating the reader with himself in his knowledge. A good example is the introduction of Charles Bovary into the schoolroom at the beginning of Madame Bovary, when the writer and others are supposed to be witnesses of his advent. ${ }^{15}$ Another instance in the same book is the mention, without comment, of the "pavilion at the angle of the wall," to which Emma directs her solitary walks at Tostes. The practice of participation by the author is common in Maupassant, one of whose regular procédés is to begin the relation of an adventure as if it were something pertaining to current gossip, or an incident told among friends. His "I" corresponds in these cases to Flaubert's "we" at the beginning of Madame Bovary. His own creations are brought in as if they were events known in the world familiar to author and reader alike. ${ }^{16}$

Another device used by both men is to relate a description to life by means of some picturesque or vivid detail. For instance, when the river at Yonville-l'Abbaye is pictured, we are told that it is there that the boys of the neighborhood fish. Sometimes a detail of this kind seems to obtrude itself unnecessarily upon our notice, as in the case of the blue seal upon the letter brought to Charles Bovary by night from "Les Bertaux." 17 In Maupassant the procedure is frequent. Here is an example taken from the opening paragraph of Notre Coeur: "Un jour Massival, le musicien, le célèbre auteur de

${ }^{13}$ For example, M.B., p. I6; U. V., p. 22.

14 For example, beginning of Sal. $\quad{ }^{15}$ M.B., p. I.

${ }^{16}$ For example, M.Par.: L'Inconnue, p. 109, L'Épingle, p. 187, Çà ira, p. 233 ; Le Horla, etc.

${ }_{17}$ M.B., p. 95 ; ibid., p. 15. 
«Rebecca», celui que, depuis quinze ans déjà, on appelait «le jeune et illustre maître», dit ..." What seem at first sight to be superfluous details are much less common in Maupassant than in Flaubert. The following is an example of what might be called one. Boule de Suif has just offered M. Loiseau some of her chicken "... sur la pointe d'un couteau toujours logé dans sa poche, il enleva une cuisse toute vernie de gelée ..."18

In the works of both Flaubert and Maupassant there is considerable employment of technical detail of various kinds. Medical and pathological particulars, frequently used with caricatural intent, are found in connection with the "pied bot" of Madame Bovary, with the diphtheria case of $L$ 'Education sentimentale, with the mineral springs of Mont-Oriol, with the folly of Madame Hermet, as well as in many other places. ${ }^{19}$ Financial items in the matter of business dealings, of inheritances, and of other money transactions recur constantly in Flaubert's novels and in Maupassant's romans and nouvelles. Examples are the manoeuvres of Lheureux, of Frédéric, of Bel-Ami, of Andermatt, and of many others. ${ }^{20}$ Various other scientific or pseudoscientific details are largely used by Flaubert, as in the erudite dissertations of Salammbo and the absurd discussions of Bouvard et Pécuchet. Nearest to these in Maupassant are the many local words employed, without explanation, in the accounts of the latter's travelings in Algeria. ${ }^{21}$

Particulars regarding food, costume, furniture, especially when thése are of unusual kinds, are very common in Flaubert, and less common, though still constantly discoverable, in Maupassant. Descriptions of such things in the latter, where they are found, are less extensive than in the former, Maupassant seeming to be here less "bourgeois" in his interest than Flaubert. Examples of the details under discussion are to be found in the accounts of the feasts and of the costumes of the heroines in Madame Bovary and in

18 B.d.S., p. 25.

19 M.B., pp. 24I-58; L'Ed.S., pp. 40I-4; M.-O., pp. 22I-30, etc.; L.M.G.: Madame Hermet, pp. 253-67; Sal., p. 45, etc. ; S.L'E., pp. 85-92; etc.

${ }^{20} M . B .$, pp. 13, 25, 262-63, etc.; Sal., pp. 78-84, etc. ; L'Ed.S., pp. 139-40, etc. ; B.e.P., pp. 14-17, etc.; $B .-A$., pp. 127-28, etc.; $M .-O$. , pp. II, 29, 178-79, etc.; $M$. Har.: L'Hêritage, pp. 88-89, etc.; U.V., pp. 306-7; etc.

${ }^{21}$ For example, $A u$ S., p. 37, "le goum de l'agha de Saida"; p. 40, "bien au delà du chott”; etc.; cf. Kipling. 
Salammbo, as well as of the house-furnishings in both books. ${ }^{22}$ Instances of the same kind of thing in Maupassant are the descriptions in Notre Coeur of the dinner given by Mme de Burne, and of the fittings of that lady's house. ${ }^{23}$ Some specific details, such as the use of the word "acajou" in connection with furniture, and the introduction of secretaries, with or without secret drawers, ${ }^{24}$ which are similar in the two men, are probably to be attributed to a common acquaintance with prevailing fashion.

There is frequent reference in both authors to historical events. Sometimes this mention is confined to the giving of the date or the naming of the event. ${ }^{25}$ Sometimes the fortunes of the personages are closely related to the historical situation, reference to the character being interwoven with description of the fact, as in numerous passages of L'Education sentimentale or in Maupassant's stories of the War of $1870 .^{26}$ Sometimes extracts from history are given in connection with descriptions of places. Parles Champs et par les Grèves furnishes good examples of this. ${ }^{27}$ Some instances are found in Maupassant's accounts of his travels. ${ }^{28}$ An episode of Norman life calls forth from him also on one occasion some facts of Norman history. ${ }^{29}$ A very frequent form of historical reference in the works of the two authors, accompanied sometimes by citations, is that to well-known writers or other famous men, both contemporary and belonging to the past-for example, to Sir Walter Scott, to Rousseau, to Voltaire, to Robespierre, to Napoleon, to Balzac, etc. ${ }^{30}$ Perhaps

22 For example, M.B., pp. 38-39, 43-45, 69, 83, 179, etc.; Sal., pp. 4-5, 14, 103-4, 248-49.

${ }^{23} B .-A$., pp. 120-21, 123, 125; N.C., pp. 15, 38, 48, 80, 146, 185, 192-93, etc.; N.C., pp. 5-7.

${ }^{24}$ For example, $M . B$. , p. $366 ; M .-O .$, p. 70 ; U.V., p. 33; M.B., p. 478; U.V., pp. 33, 240.

${ }^{25}$ For example, U.C.S., p. 42; L'Ed.S., pp. 424-25, etc.; C.d.l.B.: SaintAntoine, p. $223 ;$ L.V.E., pp. 109-10.

${ }^{26}$ L'Éd.S., pp. 409, about 500, etc.; B.d.S.: S.-A.; etc.

${ }^{27}$ P.l.C.e.p.l.G., for example, pp. 13-17, 19, 52-53, etc.

${ }^{28}$ For example, $A u S$., pp. 186, 217-30, etc.

${ }^{29}$ L.R.d.M.H., pp. 32-33.

${ }^{30}$ For example, $M . B$., pp. 5I, 80, 8I, I15, 125, I47, 244, etc. ; L'Éd.S., pp. I5, 19, 21, 39, 41-42, 105, 195, etc.; Sal., pp. 144-45, 318-19, 335, etc.; B.e.P., pp. 5, 97 , I37, etc.; U.V., pp. 3, 33; B.-A., pp. 93-94, 197; M.-O., pp. II4, I5I; M. Par., pp. 255, 264, 268; L.R.d.M.H., pp. 26I-62; etc. 
here might be included Maupassant's mention of Flaubert once or twice in a rather gossiping way, to tell how he met certain people at Flaubert's, or how the latter made such and such a remark on such and such an occasion. ${ }^{31}$ In one passage Maupassant narrates a visit to the puppet-show of "Saint-Antoine" with Flaubert and Bouilhet, linking this and other visits thereto with the remembrances of his childhood. ${ }^{32}$ Of historical import also for the period to which they belong, even if not unique of their kind, are the pictures given by Flaubert and Maupassant of contemporary life, whether in France or abroad.

Throughout their works both authors note the sounds proper to their descriptions. Sometimes we are invited to listen to the animals in the country, especially to the crowing of cocks and the barking of dogs. ${ }^{33}$ Sometimes it is the ringing of bells that we hear, or the passing of vehicles, or the confused murmur or more definite noises of a city. ${ }^{34}$ Sometimes a character pays attention to the beating of her own heart. ${ }^{35}$ Very often the effect of the sound is heightened through being opposed to the impression of silence or of silence and darkness. Most frequently mentioned in this connection is the striking or ticking of a clock or watch in the stillness of night, often in a death chamber. ${ }^{36}$ Silence is occasionally emphasized, on the other hand, through the contrast with slight noises, such as those made by the little wild creatures in the underbrush at night, or by the mysterious denizens of the sea. ${ }^{37}$

As well as to sounds, Flaubert and Maupassant call attention very frequently to odors, pleasant or unpleasant, natural or artificial. ${ }^{38}$

${ }^{31}$ For example, $A$ u S., pp. 7, I9I, I96; M. Par., p. 264 ; L.p.R., p. 269.

32 L.R.d.M.H.: Souvenirs, pp. 237-44.

33 For example, M.B., pp. 17, I8, I90, 203, 221, 466; L'Ed.S., pp. 463, 467; U.C.S., pp. II, I4; U.V., pp. 19, 21-22, 50, I19, I34, 343; C.d.l.B.: Pierrot, pp. 5I-57, Les Sabots, p. 99, Un Coq chanta, pp. 184, I88, 191, L'Aventure de Walter Schnaffs, p. 241, La Tombe, p. 253; and so on.

34 For example, M.B., pp. I53, 364, 393, 80, 353; L'Éd.S., pp. 70, 71, 76, etc. ; Mlle. F., p. 26 ; B.-A., pp. 50, 53; U.V., p. $354 ;$ N.C., p. 7I ; etc.

${ }^{35}$ For example, $M . B .$, pp. $438-39 ; U . V$., p. I9. .

${ }^{36} M . B .$, p. 454 ; P.e.J., p. II3 ; etc.

37 M.B., p. 275 ; U.V., pp. 18-19; L.p.R.; L'Épave, pp. 79-80.

${ }^{38}$ For example, Sal., pp. 34, 56, 61, 94-95, I32, 178-79, 247, etc.; M.-O., pp. 96, Iог, I03; B.-A., p. 45 ; C.d.L.: En Voyage, pp. 244-45; etc. 
The word "nauséabond" is common in both. ${ }^{38}$ The effect of odors on man is observed. ${ }^{40}$

Much space is likewise given to color. Sometimes color is piled upon color, ${ }^{41}$ this being done in places in order to produce a ridiculous or ironical effect. Thus Charles Bovary, on his first appearance, is decked out in an absurd combination of colors. ${ }^{42}$ Thus also the tapestries in Jeanne's room are executed according to a most bizarre color-scheme. ${ }^{43}$ In this latter passage it almost seems as if Maupassant were making fun of the practice of adding color to color. Frequently two contrasting colors are mentioned together, as in the case of the pigeons of Madame Bovary and Boule de Suif. ${ }^{44}$

Enumerations are frequent in the writings of the two men. In Flaubert their more usual form is that of a piling up of different details in an effort after completeness. A good example is furnished by the account of the precious stones in the caverns of Hannibal, where an attempt is made not only to mention as many different kinds of gems as possible but also to differentiate them according to origin and the nature of the reflection they cast. ${ }^{45}$ In Maupassant generally and occasionally in Flaubert enumerations consist of a bringing together of similar details in order to give prominence to some particular point. ${ }^{46}$ The effect resulting from the former type of enumeration tends to be that of vagueness; from the latter, that of emphasis. Instances are the naming of many animals in La Légende de Saint Julien l'Hospitalier, ${ }^{47}$ in order to portray the orgy of slaughter in which Julien indulges, and the noting of the multitudinous flowers and insects in the thicket visited by Jeanne and Julien, in order to produce the impression of heat and swarming life. ${ }^{48}$

When an author restricts himself in explanation or description to those things alone which may be perceived by the senses, it seems

${ }^{30}$ For example, Sal., p. 34 ; L.V.E., p. 147; S.lEE., p. 103; etc.

${ }^{40}$ For example, M.B., pp. 288-89; L.p.R.: Sauvée, p. 175.

41 For example, Sal., p. 176; M. Par., p. 58.

42 M.B., p. 2.

48 U.V., pp. 14-15.

${ }^{4}$ M.B., p. 150, "leurs pattes roses et leurs ailes blanches"; B.d.S., p. 7I, "une armée de pigeons blancs, ..., avec un oeil rose (taché, au milieu, d'un point noir)."

${ }^{4}$ Sal., p. 176.

${ }^{46}$ For example, M.B., pp. 3, 10, 36; Sal., p. 176; L’Éd.S., pp. 47-48, 51 ; T.C.: L.L.d.S.J.l'H., p. $9 \mathrm{I} ;$ U.V., pp. 50-5I ; B.-A., pp. 56, 106, 136; etc.
${ }^{47}$ Page 9I.
$48 U . V$., pp. 50-5I. 
inevitable that he should have to explain or describe through suggestion the many things which lie beyond the domain of the senses, but which he cannot help introducing because they are inseparable from life. Hence the large use of symbolic expression in Flaubert and Maupassant as in other realistic writers. Hence also, resulting perhaps in part from the implications of such expression, a certain confusing of the departments of life, men being represented as animals, animals and things as human. Such representation is common in the two authors under consideration.

Of pure symbolism there are examples on almost every page of the works of both. In Flaubert we have, for instance, Emma Bovary's wedding bouquet as the symbol of her early hopes and their disappointment, or the "zaimph" as the symbol of the power of Carthage. ${ }^{49}$ In Maupassant's Bel-Ami the train is the symbol of Duroy's progress. ${ }^{50}$ Or the symbolical thing may be an act or an event, as where the horse of Charles shies on being turned for the first time into the yard of the Bertaux farm, or where the rain at the beginning of Une Vie forms the first great sorrow of Jeanne's existence and suggests what is to come. ${ }^{51}$ In one of Maupassant's short stories the song of a nightingale symbolizes the passages in a love affair taking place within sound of the song. ${ }^{52}$ Sometimes one of the personages is made symbolical. Thus the old servant of the "Comices agricoles" embodies the servitude of the peasant woman, and the dumb shepherd Gargan in Les Bécasses, who is always knitting, represents the unchangingness of peasant life and of the place where he lives. ${ }^{53}$ There may be a certain symbolism in names, as where Félicite of Un Coeur simple suggests both the peasant woman's fatalistic acquiescence in circumstances and, by contrast, the real misery of her lot; or where "Bel-Ami" calls to mind both the impression which Duroy makes upon others and, by contrast, the real character of the man.

In both Flaubert and Maupassant psychology is often-not always ${ }^{54}$-indicated indirectly through the expression of a sentiment

49 M.B., p. 94 ; Sal., for example, pp. 99, 108-10, 232, etc.

${ }^{50} B$.- $A$., for example, pp. $53,59,107,136$, etc.

51 M.B., p. $17 ;$ U.V., p. 5.

52 L.M.T.: Une Partie de campagne, pp. 108 ff.

53 M.B., pp. 208-9; M. Par., pp. 201-16.

${ }^{54}$ For example, T.C.: U.C.S., pp. 23-26, etc.; L.P.R., pp. 48 ff. 
by means of the corresponding sensation. ${ }^{53}$ Emma, for example, after Léon's departure remains "dans un froid horrible qui la traversait." Jeanne, on the day of her wedding, has "une grande sensation de vide en tout son corps." ${ }^{57}$ Gesture, action, conversation, appearance, attitude, or attendant circumstance may furnish the key to the psychology of a character. The little Hannibal, asleep, extends his small arm "dans une attitude impérative." ${ }^{58}$ In La Roche aux guillemots the last arrival sits down at table, "se frottant les mains." Emma dies with a horrible laugh. ${ }^{60}$ Georges Duroy, as he walks along the sidewalk, shoulders the people he passes out of his way. ${ }^{61}$ Peasant remarks are, as one would expect, characterized by naïveté in both authors. ${ }^{62}$ The uprightness of Madame Arnoux' mind seems to correspond to the regularity of her features, ${ }^{63}$ the narrowness of Miss Harriet's life to the meagreness of her frame. ${ }^{64}$ Such characterization by means of external manifestation may seem to be wholly inadequate; yet it has been said of Maupassant, and it might be said of Flaubert, that he has probably all the psychology necessary for the persons he depicts. ${ }^{65}$ Conversely the following remark made regarding Flaubert may be applied likewise to Maupassant, that he sometimes represents a sentiment by means of a landscape, or part of a landscape, or through a figure from nature. ${ }^{66}$ Changes in the feelings of characters accompany changes in the seasons or the weather. ${ }^{67}$ Both men express more than once the feeling of peacefulness and satisfaction experienced on a beautiful moonlight night. ${ }^{68}$ Emma's impatience and boredom are embodied in the monotony of the scene upon which she gazes.

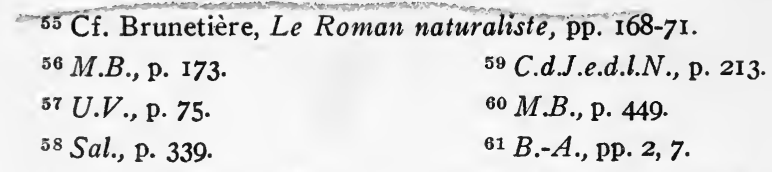

${ }^{62}$ For example, M.B., pp. 27-28, 209, etc.; dialogue in Le Vieux: C.d.J.e.d.l.N., pp. 91-104.

${ }^{63} L^{\prime} E d . S$., pp. 6, 65, 120-22, etc.

${ }^{64}$ M.Har., pp. I-36.

${ }^{65}$ Lemaitre, Les Contemporains (edition of 1887), I, 307.

${ }^{66}$ Cf. Brunetière, L.R.N., pp. 174 ff.

${ }^{67}$ For example, M.B., pp. 87, 48I; Sal, p. 353; U.V., pp. 368-69; C.d.L., pp. 8-12.

${ }^{68}$ For example, M.B., pp. 274-75; Sal., pp. 55-56; U.V., pp. 70-71, 72; C.d.L., pp. $8 \mathrm{ff}$. 
Elle commençait par regarder tout alentour, pour voir si rien n'avait changé depuis la dernière fois qu'elle était venue. Elle retrouvait aux mêmes places les digitales et les ravenelles, les bouquets d'orties entourant les gros cailloux, et les plaques de lichen le long des trois fenêtres, dont les volets toujours clos s'égrenaient de pourriture, sur leurs barres de fer rouillés. ${ }^{69}$

Jeanne's sadness on her return from Corsica is typified by the mournful autumn landscape. "... après avoir regardé quelque temps le ciel où roulaient des nuages sombres, elle se décida à sortir." Was it the same country as in May? Where were "la gaieté ensoleillée des feuilles, et la poésie verte du gazon"? "Et cette griserie de l'air chargé de vie, d'aromes, d'atomes fécondants n'existait plus." The shivering poplars sent down a sorrowful and incessant rain of yellow leaves. The shrubbery was as lamentable as a death chamber, deprived as it was of its greenness; "et le murmure des feuilles tombées et sèches que la brise poussait, remuait, amoncelait en tas par endroits, semblait un douloureux soupir d'agonie."'70 The following are examples of figures expressing sentiments.

Les bonheurs futurs, comme les rivages des tropiques, projettent sur l'immensité qui les précède leurs mollesses natales, une brise parfumée, et l'on s'assoupit dans cet enivrement, sans même s'inquiéter de l'horizon que l'on n'aperçoit pas. ${ }^{71}$

Elle se sentait enfoncée dans un trou aux bords inaccessibles, dont elle ne pourrait jamais sortir, et toutes sortes de malheurs restaient suspendus sur sa tête comme des gros rochers qui tomberaient à la première occasion. ${ }^{72}$

Many other examples of the same kind of thing might be given.

A type of figurative expression in both Flaubert and Maupassant, particularly frequent in the latter, usually found in the form of a comparison in the former, is that of reference to man as "la bête humaine," or even, in further depreciation, as "l'insecte humain."" Maupassant also in one passage exposes the theory that every man is like some animal. ${ }^{74}$ Many different animals are used for purposes of

$$
\begin{array}{ll}
{ }^{69} \text { M.B., p. 61. } & { }^{71} \text { M.B., p. 132. } \\
{ }^{70} \text { U.V., pp. I18-19. } & { }^{72} \text { L.M.T.: L'h.d'u.f.d.f., p. } 83 .
\end{array}
$$

${ }^{73}$ For example, M.B., pp. 209, 256 (comparison to animal) ; Sal., pp. 70, 221. etc.; L.M.T.: En F., p. I79; M.Har.: En V., p. 295; S. l'E., pp. 38 ff., etc.; Mlle F.: R.à.M.A.W., p. 284. Cf. the practice of Balzac, Zola, etc.

${ }^{74}$ L.S.R., p. II. 
comparison. ${ }^{75}$ Sometimes a comparison is repeated; for example, the thought of the mercenaries as being like lions occurs more than once in Salammb $\hat{o}^{78}$ while certain types of women are described by Maupassant as resembling hens. ${ }^{77}$

Closely allied to the picturing of man as a "bette" is the depicting of animals as human. This is much more common in Flaubert, somewhat less common in Maupassant, than the previous comparison. In both authors the representation is accomplished through the attribution of actions which could be performed only by a reasoning being. The monkey in the Temple of Tanit in Salammbô seems to protest against the profanation of the temple $;^{78}$ the old dog in La Peur acts as if possessed by the same terror as his human companions. ${ }^{79}$ This is especially true in the cases which have to do with the ill-treatment of animals. Examples are the mutilated elephants in Salammbô and the poor old horse "Coco" in the story of that name. ${ }^{80}$

Things also are constantly personified by both Flaubert and Maupassant. For example, the "Hirondelle" in Madame Bovary and the "zaimph" in Salammbô give the impression of being alive. ${ }^{81}$ Thus also do the pendulum of Jeanne's clock in Une Vie and Bernard's little boat, which founders in Sur l'Eau, and for which he grieves as for a friend. ${ }^{82}$

In description there are many similarities between the two authors in method of describing and in things described. Both use sometimes "massed," sometimes "scattered" description. The best example of the latter type is perhaps Madame Bovary, which exhibits also, for instance with regard to the personal appearance of the chief personage, the fault which is likely to result from this method-vagueness of general impression, with occasional discrepancy. ${ }^{88}$ "Scattered"

${ }^{75}$ For example, Sal., pp. 3, 18, 221 ; B.-A., pp. 63, 109, 112; M.Par.: La C., pp. 127,128 , etc.

${ }^{76}$ Pages 3, 34-35, 107, 387.

${ }^{77}$ U.V., p. 62; L.M.T., p. 16; M.Par.: Tribunaux rustiques, p. 179.

78 Sal., p. Iог. ${ }^{79}$ C.d.l.Béc., pp. 8I-84.

80 Sal., p. 186; C.d.J.e.d.l.N., pp. 146-56.

81 M.B., pp. 107, 305, 363, etc.; Sal., pp. 99, 108, 109-10, etc.

82 U.V., pp. 55, 123, etc.; S. l'E., pp. 166-67.

${ }^{83}$ For example, M.B., p. I9, "Ce qu'elle avait de beau, c'étaient les yeux; quoiqu'ils fussent bruns, its semblaient noirs à cause des cils, ..." " Cf. p. 45, where it is said of the same eyes that they are "noirs à l'ombre et bleu foncé au grand jour." 
description is less suitable for short stories than for novels, inasmuch as it needs greater space for its development than is afforded by the few pages of a conte. It is therefore employed less by Maupassant than by Flaubert, and where it is used is of a rather different kind. Instead of giving certain details to which certain other details will be added in a subsequent passage, Maupassant's plan is rather to furnish at once sufficient to form a complete picture of the person, place, or thing to be described; then, if he returns to the description, it is either in order to emphasize further some detail already mentioned or to record the changes produced by circumstances. Examples can be found in any of his novels. In Flaubert's Trois Contes and in Maupassant's short stories "massed" description is the rule. It is, of course, found also in the novels, where many things are described only once. Here again Flaubert sometimes tends to vagueness through the employment of a multitude of details without any sufficiently outstanding single detail. ${ }^{84}$ It is possible that Maupassant may have been influenced in the direction of clearness by seeing the superfluity of detail in certain passages of his master's works. Certain it is that his own pictures are rendered singularly clear, vivid, and complete in very few words. He makes one of his characters express his formula thus:

Avec un paysage brossé en quelques lignes et une petite histoire dite en quelques phrases, on peut donner, croyez-vous, le vrai caractère d'un pays, le faire vivant, visible, dramatique. ${ }^{85}$

In his later work, as in Un Coeur simple, Flaubert approximates to Maupassant's simplicity. Take, for example, the following description of Félicités personal appearance, the only one in the story:

Son visage était maigre et sa voix aiguë. A vingt-cinq ans, on lui en donnait quarante. Dès la cinquantaine, elle ne marqua plus aucun âge:et, toujours silencieuse, la taille droite et les gestes mesurés, semblait une femme en bois, fonctionnant d'une manière automatique. ${ }^{86}$

Everything in this passage leads up to the keynote of the description which is expressed in the words italicized. The use of such a "keynote" is a frequent device for the imparting of unity to a picture. For instance, the thought of the cathedral as a setting for Emma's attractiveness gives that building a certain aspect in the eyes of Léon.

${ }^{84}$ For example, Charles Bovary's cap, M.B., pp. 2-3.
${ }^{85}$ C.d.L.: En V., p. 243.
${ }^{86}$ T.C.: U.C.S., pp. $5-6$. 
L'église, comme un boudoir gigantesque, se disposait autour d'elle; les voûtes s'inclinaient pour recueillir dans l'ombre la confession de son amour: les vitraux resplendissaient pour illuminer son visage, et les encensoirs allaient brûler pour qu'elle apparût comme un ange, dans la fumée des parfums. ${ }^{87}$

To take now an example from Maupassant-the lifelessness of the winter season is the main motif in the following passage from Une Vie:

Les fermes, isolées dans leurs cours carrées, derrière leurs rideaux de grands arbres poudrés de frimas, semblaient endormies en leur chemise blanche. Ni hommes ni bêtes ne sortaient plus; seules les cheminées des chaumières révélaient la vie cachée par les minces filets de fumée qui montaient droit dans l'air glacial.

La plaine, les haies, les ormes des clotures, tout semblait mort, tué par le froid. De temps en temps, on entendait craquer les arbres, comme si leurs membres de bois se fussent brisés sous l'écorce; et parfois une grosse branche se détachait et tombait, l'invincible gelée pétrifiant la sève et rompant les fibres. ${ }^{88}$

It has been generally allowed that description preponderates over narration in Flaubert. This is true of his earlier novels, which may be said to proceed often by a series of descriptions. ${ }^{89}$ In some of his later works, however, the style is rather narrative than descriptive; for example, in Un Coeur simple and Bouvard et Pécuchet. It is here that Flaubert connects most closely with Maupassant, whose general manner is narrative. This we should expect from a man the greater part of whose work consists of short stories. Maupassant more or less carries the method of his short stories into his novels. Of both men it is true that they avoid for the most part long, unbroken descriptive passages and introduce details of description as required. Descriptions are very frequently generalized by both through reproduction of the permanent features in a picture. Thus, in the account of the sun's rising over Carthage, Flaubert, while keeping his representation sufficiently distinctive, yet seizes upon those attributes which might be predicated of any similar sunrise. ${ }^{90}$ Thus also in like scenes of Maupassant's. ${ }^{91}$ Among the most striking examples of this generalization are the pictures given by both authors

87 M.B., p. 33I.

88 Page 158.

${ }^{89}$ Cf. Brunetière, L.R.N., pp. 179, etc. ${ }^{90}$ Sal., p. 21.

${ }^{91}$ For example, U.V., pp. 22, 96, 245. 
of calm and beautiful moonlight nights, in which there is conveyed the very charm of peace and limpid light which we have all experienced, which has been known presumably since the beginning of time, and which will continue supposedly to be known until the end. ${ }^{92}$ The same tendency to generalization is observable in character description. Both men depict, for example, the eternal peasant and, to a certain limited extent, the "eternal feminine." This tendency to generalize seems, at first suggestion, to contradict the theory of the "characteristic detail." On second thought, however, it will be seen that the two are not incompatible. A scene or a person to be recognizable must possess, on the whole, attributes that come within the range of our knowledge; when such attributes have once been grasped, we look for the distinctive trait which marks off that scene or person from others. A moonlight night is a moonlight night, whether in Carthage or at "les Peuples"; but in the one instance the light falls upon "un collier d'or à la poitrine d'un dieu" ;93 in the other it illuminates "le tilleul et le platane." Hannibal and Andermatt are both "men of affairs ;" but the one hoards his wealth in Carthaginian cellars; while the other utilizes his in modern speculation..$^{95}$

Description is accomplished very frequently in both authors through the eyes of one or more of the characters, either moving or standing still. ${ }^{96}$ If the character is moving we have described what he sees as he advances; if he is standing still the recital is of what lies or passes before him. Sometimes here Flaubert's efforts after completeness may lead him into discrepancy: he may record more than anyone could possibly see in a transient glance, as where Emma is made to read the long descriptions on the pictures observed by her as she traverses the billiard-room at "La Vaubyessard." ${ }_{97}$ Maupassant appears to avoid this kind of mistake, perhaps through noticing its effect in his master's work. ${ }^{98}$ On the whole, however, description through the eyes of a personage is consistent in both writers; that is, no more is reported than would be actually seen by the particular

92 For example, M.B., pp. 274-75; Sal., pp. 55-56; U.V., pp. 16-19, 70-71, 237 ; C.d.L., pp. 8-9. See above, p. 46.

93 Sal., p. 55. 94 U.V., p. 7 I.

95 Sal., pp. 166 ff.; M.-O., p. I1, etc.

${ }^{96}$ For example, Sal., pp. 92 ff.; L'Ed.S., pp. 6-7; N.C., pp. 116-17; U.V., pp. $23 \mathrm{ff}$.

${ }^{97}$ M.B., p. 66.

98 See above, p. 49. 
character or characters under the specific circumstances. For instance, the first picture of Mme Arnoux is as follows. Frédéric is looking at her from a little distance.

Elle avait un large chapeau de paille, avec des rubans roses qui palpitaient au vent, derrière elle. Ses bandeaux noirs, contournant la pointe de ses grands sourcils, descendaient très bas et semblaient presser amoureusement l'ovale de sa figure. Sa robe de mousseline claire, tachetée de petits pois, se répandait à plis nombreux. Elle était en train de broder quelque chose; et son nez droit, son menton, toute sa personne se découpait sur le fond de l'air bleu. ${ }^{99}$

It will be noticed that, owing to where Frédéric was standing and to the position in which Mme Arnoux was sitting with her embroidery, her large hat would conceal her eyes and the upper part of her face; they are, therefore, not described. Her gown, being ample, would hide her feet; accordingly no mention is made of these. ${ }^{100}$ The description is otherwise comprehensive, as Frédéric's eager eye would take in all he could see. An example of the same kind of thing in Maupassant is to be found at the end of Bel-Ami. Du Roy is leaving the church after his marriage; he does not see the crowd there, for he is thinking only of himself. Then it strikes him that the throng is a tribute to himself; at once he notices the concourse! "Lorsqu'il parvint sur le seuil, il aperçut la foule amassée, une foule noire, bruissante, venue là pour lui, pour lui, Georges Du Roy. Le peuple de Paris le contemplait et l'enviait." $\mathrm{He}$ imagines future triumphs. "Puis, relevant les yeux, il découvrit là-bas, derrière la place de la Concorde, la Chambre des députés. Et il lui sembla qu'il allait faire un bond du portique de la Madeleine au portique du Palais-Bourhon."101 Thus what is seen is often an indication of the character or condition of the one who sees. For example, monotony is sometimes indicated through noting the passing and repassing of the same people across an unchanging scene. ${ }^{102}$ Description through the eyes of a personage is closely connected with a device already mentioned, ${ }^{103}$

${ }^{9} L^{\prime} E$ C.S., p. 6.

${ }^{100}$ However, on p. 12, in his remembrance of how'she looked, he recalls the appearance of her feet. Probably he noticed them, not at the first glance, but as he considered her afterwards.

${ }^{101} B$.- $A$., pp. $572-73$.

${ }^{102}$ For example, $M . B .$, pp. 89-90; U.V., pp. 344-45.

${ }^{103}$ See above, pp. 48-49, 50. 
that of bringing in a description where it will be of greatest significance. This is not necessarily where the person, place, or thing to be described is first spoken of, although often so, especially in Maupassant. ${ }^{104}$

A very common device is description in a ray, or in the rays, of a natural or an artificial light. ${ }^{105}$ Sometimes the person or thing is outlined against the light. ${ }^{106}$ Sometimes objects in a scene are distinguished through their glittering when the light catches them $;{ }^{107}$ sometimes they stand out, as the light strikes them, against other parts of the scene left in shadow or in dim light. ${ }^{108}$ The effect of faint light and of shadows caused by light is also described. ${ }^{108}$ At times the object is represented as changed in appearance by the nature of the light. ${ }^{110}$ Sometimes the reflection of a light in bright objects is pictured, ${ }^{111}$ or little lights appear in darkness. ${ }^{112}$ Natural light is occasionally contrasted with artificial. ${ }^{113}$

Just as description of the external appearance of persons, places, and things is achieved through the eyes of spectators, so characterization is accomplished in both Flaubert and Maupassant partly through a retailing of the effect produced on others by the character in question. Much of what we know of Mme Bovary, of Mme Arnoux, of Mme Andermatt, or of Mme de Burne comes to us through what others think or say of them. ${ }^{114}$ The same is true of many other

104 For example, the eyes of Mme Arnoux are not described until p. 192, although mentioned many times before that. Her other features are described when first we see her, on p. 6. This is perhaps to emphasize Frédéric's timidity in approaching her ( $L^{\prime} E d . S$.). In Une Vie, Julien is described fully when we first see him, because his appearance is important for the story.

105 For example, Sal., p. 160; M.B., pp. 188-89; F.c.l.M., pp. 96-97; L.P.R.: Mlle Perle, p. I29; cf. Brunetière, L.R.N., pp. 167-68.

${ }^{106}$ For example, L'Ed.S., p. 6; U.V., p. 72.

${ }^{107}$ For example, Sal., p. 199; M.-O., p. 98.

${ }^{108}$ For example, M.B., p. 66; U.V., p. 236.

${ }^{109}$ For example, M.B., p. 16; Sal., p. 55; L'I.B.: Le C. d’O., p. 93 ; U.V., pp. 210-11.

${ }^{110}$ For example, T.C.: L.L.d.S.J.lH., p. 112; F.c.l.M., p. 82.

111 For example, $M . B .$, p. $18 ; B .-A$., p. 128.

112 For example, $M . B .$, p. 73 ; U.V., p. II.

113 For example, M.B., p. 33I ; C.d.L.: La Nuit, p. 222.

114 For example, M.B., pp. 23-24, 31, 32, 54, 58, 59, etc.; L'Ed.S., pp. 54, 68, 98, etc. ; $M .-O$., pp. 129-30, etc.; N.C., pp. I, 33-35, 53-60, etc. 
characters. The information is conveyed in dialogue or monologue, direct or indirect, or in narrative. For example, Emma is discussed by the first wife of Charles and by his mother, by Lheureux, by Homais, by the busybodies of Yonville; and we have related to us at length the thoughts of Charles, of Léon, of Rodolphe, regarding her. In the same way Mme de Burne forms a constant subject of conversation and of thought for her circle, especially for Mariolle. ${ }^{115}$

In the two authors under discussion the reader is struck by the very large use made of contrast, its presence being almost universal. The types of contrast are numerous. One frequent form is that of the opposition between character and surroundings. For instance, the daintiness of Mme Arnoux stands out against her sordid environment on the deck of the steamer where we first see her; or, to take an example from Maupassant, the innocence of the girl Yvette is markedly in contrast with the milieu in which she lives. ${ }^{116}$ The contrasts of sound and silence, of light and shadow, of natural and artificial light, of colors, have already been mentioned. ${ }^{117}$ Other contrasts are those between appearance and actuality, between nature and man, between poverty and riches, etc. ${ }^{118}$

In discussing description something has already been said of narration, which it will be unnecessary to repeat. ${ }^{119}$ This paragraph will take up some additional points. Maupassant, it has been shown, ${ }^{120}$ has relatively more narration in his works than Flaubert. With regard to plots one will notice that these are simple in the works of the two men, as one can summarize in few words the actual plot interest in any of the novels or short stories. For instance, in Un Coeur simple and Une Vie, which are much alike, the whole plot has to do with the repeated disappointments which thwart the natural affections of the heroine. The slim plot interest in the novels is amplified by means of episodes and descriptions. Some works, such as L'Education sentimentale and Bel-Ami, produce the effect of a succession of episodes, even of similar episodes, a varying measure of unity being secured through the greater or less preponderance of some character, situation, or idea. In Bouvard

115 See note 114 . 116 L'Ed.S., pp. 5-6; Yvette.

117 See above, pp. 43, 53, 44.

118 For example, M.B., pp. 149, 403-4, 72; O.P.I.: La Veillée, pp. 55-60; U.V., p. $245 ;$ C.d.J.e.d.l.N.: La Parure, pp. 59-74.

119 See above, p. 50. 120 See above, p. 50. 
et Pécuchet this piling up is used to depict the "bêtise" of the two men; in Salammbô it is employed to emphasize the splendors or the cruelties of ancient life; in Madame Bovary it serves to bring out the progressive disillusionment of the heroine. Thus also in Maupassant episode after episode impresses upon us the ruthless advance of "Bel-Ami" to social and political prominence, the infatuation of Mariolle for Mme de Burne, or the perplexity of Olivier Bertin caught between the attraction of the daughter and the desire to be faithful in devotion to the mother. ${ }^{121}$ Each of Flaubert's three short stories possesses a number of episodes and is, in fact, rather an abbreviated novel than an ordinary "short story." Maupassant's contes, with sometimes but a single episode, exhibit more clearly. on the other hand, the power to seize and perpetuate just the points essential for the making of good stories. Maupassant's relatively much greater simplicity and clearness are no more apparent in description than in narration, where again Flaubert's excessive attention to realistic detail tends to vagueness and occasionally to discrepancy. ${ }^{122}$ Some narrative passages in both authors outline the course of a character's thoughts ${ }^{123}$ rather than any succession of events, and produce a semi-descriptive impression. The same effect is accomplished by the many paragraphs in the imperfect tense narrating habitual action, ${ }^{124}$ and by the general tendency to use that tense in passages where one might possibly expect the preterite. ${ }^{125}$ A device that is employed by both authors is the immobilizing of a character in a well-defined situation in order to tell us something regarding that character through the medium of the thoughts supposed to be passing within his mind at the time. ${ }^{126}$ Thus Emma Bovary's reveries after her marriage and arrival at Tostes; thus Georges Duroy's musings on returning to his shabby room after his first evening at the Forestier's. ${ }^{127}$

121 Bel-Ami; Notre Coeur; Fort comme la Mort.

122 For example, compare difficulty of outlining story of Salammbô; compare also time of Charles' journey to Rouen, as discussed by Ernest Bovet in an article on "Le Réalisme de Flaubert," R.H.L., I (I9I I), I-36.

123 For example, L'Éd.S., p. I2; P.e.J., pp. 62-64.

124 For example, B.e.P., p. 33 ; N.C., pp. 174-75.

125 For example, L'Ed.S., p. 377 (first paragraph); U.V., pp. 6I-62 (paragraph at end of one page and beginning of next).

126 Cf. Brunetière, L.R.N., pp. 174 ff.

${ }^{127} M . B .$, pp. 48 ff.; $B .-A$., pp. 57-58. 
Dialogue and monologue, both direct and indirect, are used by Flaubert and Maupassant to characterize, to describe, and to narrate, ${ }^{128}$ never to mark time. There is much more of both dialogue and monologue in the latter author than in the former. In fact, some of Maupassant's short stories are told almost entirely in dialogue or in monologue. ${ }^{129}$ Both authors seem to possess the power of making their personages say exactly the right thing. Nothing, for example, could be more apposite than their peasant conversations. ${ }^{130}$ In this Maupassant is assisted by his free use of dialect and other special forms of speech, which are found much more rarely in Flaubert.131 Sometimes striking remarks, usually short, give the key to characters or situations. Examples are Charles Bovary's "C'est la faute de la fatalité !" at the end of Madame Bovary, and the old beggar's "J'sommes tous égaux, là devant" beside the corpses of Gilberte and Julien in Une Vie. ${ }^{132}$ There is occasionally in Maupassant a suggestion of Flaubert's famous device of "alternating" dialogue, with its attendant effect of irony, as found in the account of the "Comices agricoles."133 For example, we have the conversation at the table d'hôte of the "Hotel Splendide," or Forestier's speech to Duroy punctuated by the counting of his score at billiards. ${ }^{134}$ Maupassant is much less careful than Flaubert about using introductory verbs of saying, and occasionally goes so far as to adopt the dramatic device of inserting merely the name of the speaker at the beginning of the speech. ${ }^{135}$

In order to avoid monotony Flaubert and Maupassant carry all procedures along together; there is constant interchange of description, narration, and dialogue, two of the three or all three being sometimes combined in one paragraph or even in one sentence. ${ }^{136}$

128 For example, M.B., pp. 110-16, 85-88; N.C., pp. 25 ff., 274, 175-76.

${ }^{129}$ M.Par.: La Bête à Mầt' Belhomme; C.d.J.e.d.l.N.: La Confession, pp. $277-85$.

130 M.B., p. 209; U.V., pp. 200-204.

${ }^{131}$ For example, any of Maupassant's peasant stories; M.Har.: L'Héritage; B.e.P., p. 357 ; Sal., p. 57.

${ }_{182} M . B .$, p. $480 ; U . V$., p. $282 . \quad \quad{ }_{133} M . B$. , pp. 197 ff.

${ }_{184} M .-O$. , pp. 55-78; B.-A., pp. 80-81.

${ }^{185}$ For example, M.Par.: Tribunaux rustiques, pp. $177-84$.

${ }^{136}$ For example, L'Ed.S., p. 451 ; N.C., pp. 135-36; B.e.P., p. 135 (second sentence in second complete paragraph);B.-A. (second paragraph, first sentence); cf. Brunetière, L.R.N., pp. 180-81. 
Descriptions of persons, places, and things are constantly intermingled. Description of places or things is often combined with an account of a character's thoughts. ${ }^{137}$ A short sentence of dialogue or monologue, or a brief passage of dialogue, is not seldom employed to break a long description or narration. ${ }^{138}$ There is frequent interchange of the direct and the indirect forms of dialogue and monologue. ${ }^{139}$ Many paragraphs not of dialogue end with a short spoken sentence. ${ }^{140}$

In paragraph structure there is some likeness between the works of the two men. The combination of description, narration, and dialogue in a single paragraph has already been noted. ${ }^{141}$ The average length of the paragraph is, taken on the whole, about the same in the two. Flaubert tends more in his earlier works toward the unusually long paragraph, Maupassant more in his later. ${ }^{142}$ Instances can be found where Maupassant divides among several paragraphs descriptions which Flaubert, to judge from similar cases in the works of the latter, would keep within one paragraph. ${ }^{143}$ This may be part of Maupassant's effort after greater clearness, which was suggested before. ${ }^{144}$ Flaubert's paragraphs leave in general the impression of greater deliberate artistic unity than Maupassant's. The latter frequently uses the sentence-paragraph, a habit traceable probably in part to his journalistic experiences. ${ }^{145}$ Flaubert also employs this form, but less often $;^{146}$ constantly, however, his longer paragraphs may be summarized in a sentence, sometimes an antithetical sentence. ${ }^{147}$ The brief narrative paragraphs of the two writers are much alike in their use of short, abrupt sentences with the historic tense. Several examples follow, which are given in

${ }^{137}$ For example, M.B., pp. 61-62; U.V., pp. 19 ff.

${ }^{138}$ For example, M.B., p. 355; T.C.: U.C.S., p. $26 ;$ M.-O., pp. 133, 136.

${ }^{139}$ For example, L'Ed.S., pp. 209-10; B.-A., pp. 237-38.

${ }^{140}$ For example, L'Ed.S., p. $338 ; B .-A$., p. 195.

141 See preceding paragraph.

142 For example, M.B.; N.C.

${ }^{143}$ For example, cf. the first paragraph describing the house at Tostes in M.B. (pp. 43-44) with the first four paragraphs describing "les Peuples," in U.V. (pp. 12-13).

144 See above, pp. 49, 5I, 55.

145 See practically anywhere in Maupassant's work.

146 For example, in L'Ed.S.

${ }^{147}$ For example, cf. paragraphs on pp. 116-17, M.B.; pp. 214-15, Sal.; etc. 
parallel columns for the sake of comparison in form, not in subject. They are taken from L'Education sentimentale and Bel-Ami.

Flaubert

Pour se venger de son maitre, sans doute, le garçon se contenta de sourire [L'Ed.S., p. 153].

C'était jour de réception. Des voitures stationnaient dans la cour. Deux valets se précipitèrent sous la marquise, et un troisième, au haut de l'escalier, se mit à marcher devant lui [L'Ed.S., p. 185].

Tout à coup, Martinon apparut, en face, sous l'autre porte. Elle se leva. Il lui offrit son bras. Frédéric, pour le voir continuer ses galanteries, traversa les tables de jeu et les rejoignit dans le grand salon; Mme Dambreuse quitta aussitôt son cavalier, et l'entretint familièrement [L'Ed.S., p. 230].
- Maupassant

Elle ne parla point de sortir et fut charmante de toutes façons [B.-A., p. 162].

Et ils se rendirent dans un restaurant voisin. Duroy ne parlait plus guère. Il mangea pour n'avoir pas l'air d'avoir peur, puis, dans le jour il accompagna Boisrenard au journal et il fit sa besogne d'une façon distraite et machinale. On le trouva crâne [B.-A., p. 234].

Il s'assit et se mit à réfléchir. Il avait jeté sur sa petite table une carte de son adversaire remise par Rival, afin de garder son adresse. Il la relut comme il l'avait déjà lue vingt fois dans la journée. Louis Langremont, 176 , rue Montmartre.* Rien de plus [B.-A., p. 236].

The rather abrupt effect produced by the short sentences with the historic tense is to be observed in the foregoing paragraphs. The impression of dry precision is indeed often produced by Maupassant's work. ${ }^{148}$

There is some general resemblance also between certain descriptive paragraphs in the two authors. An example is given where the subject of the two paragraphs is the same, the description of a stagecoach.

Flaubert

C'était un coffre jaune porté par deux grandes roues qui, montant jusqu'à la hauteur de la bâche, empêchaient les voyageurs de voir la route et leur salissaient les épaules. Les petits carreaux de ses
MAUPASSANT

C'était une voiture jaune, montée sur des roues jaunes aussi autrefois, mais rendues presque grises par l'accumulation des boues. Celles de devant étaient toutes petites; celles de derrière, hautes

148 For example, C.d.J.e.d.l.N.: Une Vendetta, pp. 144-45; Toine: Le Père Judas, pp. 278-79. 
vasistas étroits tremblaient dans leurs châssis quand la voiture était fermée, et gardaient des taches de boue, çà et là, parmi leur vieille couche de poussière, que les pluies d'orage même ne lavaient pas tout à fait. Elle était attelée de trois. chevaux, dont le premier en arbalète, et, lorsqu'on descendait les côtes, elle touchait du fond en cahotant $[M .-B .$, p. Io7]. et frêles, portaient le coffre difforme et enflé comme un ventre de bête. Trois rosses blanches, dont on remarquait au premier coup d'oeil, les têtes énormes et les gros genoux ronds, attelées en arbalète, devaient trainer cette carriole qui avait $d u$ monstre dans sa structure et son allure. Les chevaux semblaient 'endormis déjà devant l'étrange véhicule [M.Par.: L.B.a. M.B., pp. 77-78].

It will be observed that the foregoing paragraphs have about the same length and begin in the same way. They mention largely the same things about the coach: the yellow color, the cumbrous body, the large wheels, the mud with which it is spattered, the three horses, one in front of the other two, by which it is hauled. There is some similarity in wording (indicated in the quotations by italics). The general impression conveyed by the Flaubertian paragraph is that of a monstrous, unwieldy vehicle; Maupassant takes monstrosity as the keynote of his picture, calls the coach a "monster," and makes the horses also monsters in order to emphasize still further the same general effect as Flaubert.

Both Flaubert and Maupassant show a special use of the short sentence for forcible effect at the end of a paragraph, chapter, or short story. ${ }^{149}$ Such sentences are of various kinds. Sometimes we find a brief, emphatic statement or an interrogative or exclamatory phrase. ${ }^{150}$ Sometimes the sentence is one of dialogue or of monologue; to this reference has already been made above. ${ }^{151}$ The sentence may contain a characteristic detail regarding a person, a place, an event, or other interest. ${ }^{152}$ It may also contain summary,

149 For example, Sal., p. I04 (third paragraph); P.e.J., p. II3 (first paragraph) ; L'Ed.S., p. 409; F.c.l.M., p. I42; T.C.: Hér.; the majority of Maupassant's short stories.

${ }^{150}$ For example, M.B., p. 26; L.P.R.: Rosalie Prudent, p. I52; M.B., p. 334; C.d.l.B.: Menuet, p. 69; M.B., p. 314; C.d.J.e.d.l.N.: Le Gueux, p. 182.

151 See above, p. 57.

-152 For example, Sal., p. 25; M.Har.: «Garçon, un Bock!» p. 241; Sal., p. 379 ; M.Har.: L'Orient, p. 324 ; L'Ed.S., p. 592 ; B.-A., p. 233. 
conclusion, or comment. ${ }^{153}$ Besides the use of interrogative and exclamatory sentences, which has already been mentioned, such sentences are further frequently employed in the usual course of paragraphs to lend variety or emphasis to the style. Examples are very numerous. ${ }^{154}$ The carefully constructed periodic sentence is more common in Flaubert than in Maupassant. ${ }^{155}$

By Flaubert transition is in general very assiduously regulated, by Maupassant much less so. ${ }^{156}$ The result in the case of the latter tends often to an effect of jerkiness. Some of the romans, for example, produce the impression of a succession of short stories rather than of one continuous long story with succeeding chapters. ${ }^{157}$ The dislike of explanation ${ }^{158}$ frequently apparent in the two writers deprives both of one useful method of transition in so far as they yield to this dislike. The difficulty of transition is specifically acknowledged by both men. ${ }^{159}$ Each employs, of course, the ordinary methods of transition: the use of adverbs or adverbial conjunctions of time, and of other means of referring back or forward to preceding or succeeding sentences, paragraphs, or chapters. The connection is constantly indicated, for instance, between consecutive chapters in Madame Bovary and Une Vie. Sometimes the transitior. is accomplished by a virtual continuation of the narrative, without break or with but little break, from one chapter to another, as between chapters VII and VIII of the first part of Madame Bovary, or between chapters V and VI of Une Vie.

With regard to vocabulary ${ }^{160}$ both Flaubert and Maupassant follow, as we should expect, the realist principle of making the

${ }_{153}$ M.B., p. 48I ; C.d.J.e.d.l.N.: Un Lâche, p. 121; T.C.: Hér., p. 190; L.S.R.: Rencontre, p. 226; Sal., p. 414; C.d.L.: La reine Hortense, p. 86.

154 For example, M.B., p. 172; B.-A., p. 282.

155 See especially Madame Bovary.

${ }^{156}$ Compare Schinz, "Notes sur le vocabulaire de Maupassant," etc., Revue des langues romanes (1909), p. 512.

${ }^{157}$ For example, U.V.; M.-O.

158 See above, under "realistic detail," pp. 38, 40.

159 For example, Maynial, La Vie et l'oeuvre de Maupassant, p. 99, quotation; Flaubert, Corr., III, 345 ; etc.

${ }^{180} \mathrm{See}$, as the foundation for the whole of this paragraph, Anna Ahlström, Etude sur la langue de Flaubert, Macon, 1899 (diss.), and Olof Bosson, Guy de Maupassant, quelques recherches sur sa langue, Lund, 1907 (diss.). 
language adapt itself to the persons and circumstances which it describes. In the main, it is true, the language of each conforms to current literary usage $;^{161}$ where it seems necessary, however, for the more exact or emphatic expression of the thought, neither hesitates to transgress the boundaries of that usage. The following passage from the Ahlström dissertation (see footnote 160 ) states the case with precision and clearness for Flaubert.

Son penchant réaliste, son besoin de produire de l'effet, pour amuser ou pour éblouir le bourgeois, lui fait rechercher des expressions adéquates à sa pensée. Lorsque le vocabulaire ordinaire ne lui suffit pas, il fait des emprunts aux langues étrangères, anciennes ou modernes, il force le français des temps passés et ses parlers actuels à apporter leur tribut et il étudie les métiers pour profiter de leur terminologie spéciale. A bout de ressources, il forge lui-même des mots et pour d'autres il en modifie la signification. ${ }^{162}$

To a greater or less extent Maupassant employs all the devices attributed in this paragraph to Flaubert. Of archaisms and neologisms, ${ }^{103}$ of erudite expressions, he uses smaller numbers than his master; in the direction of argot, of dialect, of the "language of real life," he, as one would expect, goes much further. The following paragraph is quoted as giving for him a general characterization of language.

Maupassant cherche avant tout a «faire vrai,*» à nous donner une image fidèle de la vie. Lorsqu'il prend la parole lui-même, il nous offre, en général, un langage très correct, très soigné. C'est quand il fait parler d'autres personnes de divers milieux, de culture et de position sociale différentes, qu'il faut l'épier. Il ne se contente jamais de nous

${ }^{161}$ In a class exercise (University of Chicago, February 23, 1915), where investigation was made, under the direction of Professor Jenkins, of the percentage of words of current French in a representative page of certain modern French authors, the percentage for Flaubert was found to be 59 per cent, and the average for eight other writers, of whom Maupassant was one, 72 per cent.

${ }^{162}$ Ahlström, op. cit., p. 20.

${ }^{103}$ Both use the archaism "sol" (Ah1ström, op. cit., p. 45; Bosson, op. cit., p. 25); both form compounds by hyphenating separate words (Ahlström, pp. 70-73; Bosson, pp. 51, 130). Both also overdo the use of words beginning with re. Cf. Schinz, Notes sur le vocabulaire de Maupassant, etc. (Rdlr, 1909, p. 518) ; Flaubert, Corr., III, 197, 201, 217, 229, 239, etc. 
représenter le parler de ses personnages sous une forme «retouchée», il nous le donne tel qu'il est, avec tous ses solécismes, toutes ses négligences, toute sa rudesse, toutes ses crudités. ${ }^{164}$

It will be apparent from what has been said above that Maupassant's language is, according to the general acceptation of the term, more "realistic" than Flaubert's.

In this last chapter we have been studying the very considerable resemblance between Flaubert and Maupassant in matters of literary procedure not mentioned in the preceding chapter. We have seen that they employ to a certain extent the same kinds of realistic detail, the same forms of figurative expression, the same methods in description, narration, and dialogue, the same devices in paragraph and sentence structure and in use of language. As said before, ${ }^{165}$ the procédés discussed in this chapter are, in the main, those adopted in common by the realistic writers of the day. Some which may perhaps be more distinctive of the two authors in question than of other realists are the following: time designation by means of reference to characteristic denoting season of year; description in a ray of light or in shadow; narration of the past life of a character immobilized through the medium of that character's thoughts; "alternating" dialogue; use of a short sentence to end paragraph, chapter, or story. In considering the procédés of this chapter it has not been intended, as was said before, ${ }^{166}$ to attribute to them more than the weight of cumulative testimony when taken in conjunction with other evidence presented for the relationship of Flaubert and Maupassant.

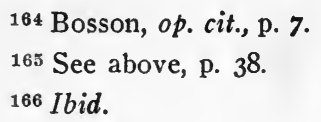




\section{CHAPTER V}

\section{RESEMBLANCES IN PLOT, INCIDENT, CHARACTERIZATION, IDEAS, AND WORDING}

In the preceding chapters there have been considered similarities between Flaubert and Maupassant in theories and procédés, as well as the history of their personal relationship. Many concrete instances of resemblance have been mentioned by way of illustration. It yet remains to discuss other specific examples of likeness between the two in fact, idea, and wording, which have, for the most part, not been noted in illustration of previous points.

There are, first of all, resemblances in what may be called "general effect." Maupassant's Le Loup, ${ }^{1}$ which narrates the killing of a huge gray wolf, has about it somewhat the same atmosphere of legendary mysteriousness as Flaubert's Saint-Julien l'Hospitalier, ${ }^{2}$ the impression being increased by certain details of likeness. In both stories the scene is laid in a past remote enough to be more or less shadowy, in both there are certain extraordinary qualities attributed to animals or to an animal, in both the events transpiring produce an abhorrence of the chase succeeding a great passion therefor. ${ }^{3}$ Likeness in general effect is also observable in Un Coeur simple and Une Vie, both of which give the impression of an accumulation of misfortunes overwhelming an unfortunate victim. There is a certain general similarity also, as was implied before, ${ }^{4}$ between some passages in Maupassant's letters and in Flaubert's. In letters written by Maupassant to his preceptor there are traces of an exaggerated and exclamatory style, foreign, as far as one can judge from the other letters in the Conard edition, ${ }^{5}$ to the former's usual epistolary manner, but exceedingly common in the latter's correspondence. $^{6}$ Appearing as they do in letters from the younger to

${ }^{1}$ C.d.L., pp. 35-44.

2 T.C., pp. 77-125.

3 S.J.l'H., p. I25; L.L., p. 36; S.J.l'H., pp. 92-93, 107-10; L.L., pp. 38, 40-42; S.J.l'H., pp. 92, г17; L.L., p. 39; S.J.l'H., pp. 93-95, 84-93, I13 ff., 103, 106 ff. ; L.L., pp. 35-36, 44, 36-44.

${ }^{4}$ See above, p. 17. 5 B.d.S.: Corr., pp. cxxv-lxxii.

${ }^{6}$ For example, Corr., I, 77, I35; II, I09, 290, etc. 
the older man, they read like remarks made by the pupil in consideration of the ideas and methods of the master.

The following passages will illustrate what is meant. They are to be compared with those quoted alongside, not in specific details, but in general manner.

\section{FlaUBERT}

L'histoire de la croix de Zola est pitoyable. Est-ce bête? mais qu'est-ce qui n'est pas bête? [Corr., IV, 349].

Oui, j'ai lu la brochure de Zola. C'est énorme! Quand il m'aura donné la définition du Naturalisme, je serai peut-être un Naturaliste. Mais d'ici là, moi pas comprendre.

Et Hennique qui a fait, aux Capucines, une conférence sur le Naturalisme! ! ! Oh! mon Dieu! mon Dieu! [Corr., IV, 364].

Et le manifeste politique de Zola menaçant la République de sombrer, si elle n'arbore l'étendard du réalisme! du naturalisme, pardon! Drôle! drôle! [Corr., IV, 365-66].

\section{Maupassant}

Zola n'est pas décoré-à cause de l'article qu'il a écrit dans $l e$ Figaro*!!!! ... Le chef du cabinet m'a dit que le ministère ne pouvait vraiment pas* lui donner la croix en ce moment!!! ... on rêve. ${ }^{7} \ldots$ En quoi un article de critique détruit-il le talent de Zola? [B.d.S.: Corr., p. cxiv].

Que dites-vous de Zola? moi je le trouve absolument fou. Avezvous lu son article sur Hugo!! son article sur les poètes contemporains et sa brochure «la République et la littérature»? «La République sera naturaliste ou elle ne sera pas», «JE NE SUIS QU'UN SAVANT» -- !!!! -(rien que cela!-quelle modestie),-«l'enqûete social»,-le document humain,-la série des formules*, - on verra maintenant sur le dos des livres «grand roman selon la formule naturaliste». Je ne suis qu'un savant*!!!!! cela est pyramidal !!! et on ne rit pas ... [B.d.S.: Corr., pp. cxx-cxxi].

The foregoing passages have been chosen for purposes of illustration because they are concerned with the same subjects: the decoration of Zola, the stupidity of the governing classes, the pretensions of Zola and the naturalists. In them will be noticed the same general tone of exasperation, the same tendency to multiply

${ }^{7}$ Word often used by Flaubert in similar places in letters; $c f .$, for example, Corr., III, 39, 244, 298; IV, 362; etc. 
emphases through the use of italics and of exclamation points, the same employment of unusual expressions.

There is some similarity between the plots of the two men. For instance, there are several stories of Maupassant's which recall Madame Bovary. The first of these to be mentioned is Une Vie, which is like Flaubert's novel in many particulars of plot. In both cases a large part of the story is concerned with marital treachery. In one case it is the wife, in the other the husband, who is the offender. The separate instances of unfaithfulness recorded are, in each book, two in number. Rodolphe and Emma in Madame Bovary, Julien and Gilberte in Une Vie, make riding a means to their intercourse and seek their rendezvous in the woods and on the countryside. The "cabane ambulante"s of Une Vie takes the place of the "tonnelle" of Madame Bovary. The two sinners, Emma and Julien, come to an unnatural end, a beggar being connected in each case with the catastrophe. ${ }^{10}$ An excursion by boat enters into the love-making of Léon and Emma, of Julien and Jeanne. ${ }^{11}$ In both stories the child of the heroine, a pet dog, revealing letters, play some part. There are frequent journeyings by stagecoach, by carriage, by train. In each case the heroine changes her place of abode during the progress of the plot. Money matters exert a considerable influence in the two, there being talk of debts, of mortgages, and of selling of possessions. Emma is ruined by her own extravagance, Jeanne by the "bonté" of her parents and herself and by the prodigality of her son. Jeanne is made unhappy by Julien's stinginess in money matters no less than Charles by Emma's wastefulness. In Madame Bovary we have Lheureux and his agents who conduct the money affairs; in Une Vie the Jew and others who come to Jeanne regarding Paul's debts. In both books there is the description of a public ceremony; in one the "Comices agricoles"; in the other the christening of the "Jeanne." 12 The account of either celebration follows the course of the lovers as they walk: Rodolphe and Emma pass from place to place, seeing the various sights of the day, and finally taking refuge in the "salle des délibérations" while the speeches are being delivered and the prizes given; Julien and
8 U.V., p. 276, etc.
10 M.B., pp. 448-49; U.V., pp. 280-82.
${ }^{9} M . B$. ., p. 234, etc.
$11 M . B$., pp. 353 ff.; $U . V$., pp. 44 ff.
${ }^{12} M . B .$, pp. $183-214 ; U . V$., pp. 56-62. 
Jeanne descend from "les Peuples" to the beach, where the christening of the boat takes place. Rodolphe makes advances to Emma, Julien to Jeanne, during the progress of the ceremony. In both stories we have a severe illness of the heroine, caused in Emma's case by Rodolphe's desertion, in Jeanne's by the shock of discovering her husband's infidelity. Emma's attack is said to be brain fever $;^{13}$ Jeanne's is not thus named, but seems to be the same thing. In both books we have a ball, a death scene, and a watch by the dead included in the progress of the plot. In both there is an element of the horrible; for example, in Madame Bovary the account of the blind beggar, and in Une Vie the narration of the death of Julien and Gilberte.

Another story which has some points of resemblance with Madame Bovary is La Parure. ${ }^{14}$. In it we have a woman who, like Emma, is, or imagines herself to be, entirely out of her element. Like Flaubert's heroine, Madame Loisel dreams of a different life, and like her, too, is invited and goes to a ball in a society to which she cannot ordinarily hope to be admitted. Like Flaubert's heroine, she enjoys the experience but is afflicted afterward by resulting sadness. Misfortune affecting the whole life follows in each case, although different in character and extent.

Also containing likenesses to Madame Bovary is the story of the little provincial who comes to Paris and forces herself into "une aventure d'amour," only to be disillusioned by her experiences. The heroine of Une Aventure parisienne $e^{15}$ has, like Emma, entertained inordinate longings for Parisian glory beneath apparent acquiescence in the monotonous course of her everyday life. Like her, she buys and reads society journals and is especially attracted by the glamor of "what Maupassant calls "des horizons de jouissances coupables et ravageantes. ${ }^{16}$ Especially does she indulge her dreams during the night, contrasting the world of her imagination with her commonplace surroundings. Here again she resembles Emma. As in the case of the Flaubertian character, the dreams of Maupassant's heroine end in disenchantment.

Between Un Coeur simple and Une Vie there are many similarities. Flaubert's Félicité is now like Jeanne, now like Rosalie, in Maupassant's story. The main thread of the plot concerns her resemblance to Jeanne. Both, simple-minded and with unusual

${ }^{13}$ M.B., p. 290.

${ }^{14}$ C.d.J.e.d.l.N., pp. 59-74.
15 Mlle F., pp. 193-205.

16 Ibid., p. I94. 
capacities for devotion, suffer from blow after blow to the affections dealt by death or disappointment, which leaves the victim aged, benumbed, and stupefied, clinging desperately to memories of the past and to the objects which recall those memories. Like Rosalie, Félicité is a faithful servant to a somewhat exacting mistress, and shows, in her mistress' interest, considerable shrewdness, bravery, and power of economy. The relation of mistress and maid in both stories becomes increasingly one of intimacy and affection, the two uniting especially in remembrances of the past. In some respects Jeanne resembles Mme Aubain, of Un Coeur simple, rather than Félicité. Both have two farms attached to their property, both lose their fortunes in later years, sell some of their possessions, and go to a less expensive house. Both spend much of their time in idle brooding, leaving the direction of affairs to the faithful servant. Both possess a son called Paul, who, after being sent to school, to which he rejoices to go for the sake of the companionship to be enjoyed, falls into irregular ways of life, contracts debts which his mother pays, and, passing unsuccessfully from one employment to another, finally marries a woman distasteful to the latter. In the course of their development both stories touch upon many like comings and goings of provincial life, and both give glimpses of fisher folk.

The next works of Flaubert and Maupassant to be compared are L'Education sentimentale and Bel-Ami. While there is considerable resemblance here, it is harder to specify than in any of the cases already taken up. Both stories deal with the career of a young man who passes through various experiences of Parisian life, the one to failure, the other to success. A certain unity is given in each case to the rambling story by relating everything to the fortunes of the chief character. Frédéric, beginning with fair chances, throws away all opportunities and accomplishes nothing, owing to his "mollesse" and lack of decision. Duroy, starting with his fortunes at an exceedingly low ebb, advances, chiefly through the aid of his mistresses and by means of ruthless self-assertion, to a position of importance beyond that for which he had hoped. At first indeed he is rather like Frédéric in want of decisiveness, but the weakness gradually vanishes as he becomes sure of himself. In other respects the two men are similar. Both dream of great things to be done and enjoyed in the future. Both possess considerable fascination for the opposite sex, having in the course of the experiences related in 
the story, love affairs progressing simultaneously with three separate women. To the delight of the successful suitor, one of these women is, in each case, the "great lady" of the story, whom each has been advised to cultivate in order to further his material interests. One love affair in both books persists through all vicissitudesthat of Frédéric with Mme Arnoux, that of Duroy with Mme de Marelle. Both men, besides, become engaged to young girls for the sake of their fortunes, Frédéric afterwards escaping from his marriage, Duroy carrying his through. It is interesting to note for revelation of the character of Frédéric that in the three instances where marriage is suggested to him it is the woman in each case who does the proposing. ${ }^{17}$ Mme Arnoux in L'Education sentimentale, Mme de Marelle in Bel-Ami, have little daughters to whom Frédéric and Duroy show attention. In both books the husband of one of the women loved dies of lung disease in the course of the story. ${ }^{18}$ The lover is present during the final scenes, assists in the watch by the dead, and looks after the funeral arrangements. Frédéric then is about to marry the widow, Mme Dambreuse, but abandons her after what he considers an insult offered by her to Mme Arnoux. Duroy accomplishes his marriage with Madeleine Forestier after the death of her husband but subsequently divorces her. On one occasion an insult to Mme Arnoux involves Frédéric in a duel with Cisy. ${ }^{19}$ Duroy also finds himself committed to a duel, in his case through an insult bestowed upon him by a rival journal. ${ }^{20}$ Some incidents of the duels are much alike. Duroy resembles rather the Cisy of Flaubert's story than Frédéric in his mechanical actions, his thirst, his desire for an accident to prevent the occurrence, his extreme terror. Frédéric and Duroy act similarly in that both look in the glass to see if they show traces of fear, whereupon both discover themselves to be pale. Both also think of the probable effect of a tragic ending on their parents. In neither duel is anyone hurt, and the event is treated by the two authors as a rather ridiculous performance. The insulting notice in a journal, from which Frédéric suffers no less than Duroy, happens to the former in an account of the duel which puts him in a most unfavorable light. In many other particulars Duroy seems to imitate Frédéric. Both come of provincial families and betake themselves to Paris against the will of their

17 L'Ed.S., pp. 362, 541-42, 561.

18 Ibid., pp. 537 ff.; $B .-A$., pp. 22 I ff.
19 Ibid., pp. 318 ff.

20 B. $-A$., pp. 230 ff. 
parents. $^{21}$ Both are poor at first, are frequently in money difficulties, and pass their lives amid surroundings of which the sordid details are given. ${ }^{22}$ Both acquire moderate fortunes during the development of the story. ${ }^{23}$ Frédéric tries to secure an invitation to the residence of M. Dambreuse, Duroy to obtain one to the house of M. Walter. ${ }^{24}$ Having been tendered the invitation, each of the two is represented on one occasion as advancing down a long series of rooms to greet his hostess, ${ }^{25}$ and on another as drawing attention upon himself by unorthodox remarks. ${ }^{26}$ Both celebrate their rise in station by purchasing new clothes. ${ }^{27}$ Each is shown to us more than once looking in the glass. ${ }^{28}$ Both make plans for election as deputy. ${ }^{29}$ In many incidents the two appear, Frédéric at least progressively so, to be self-centred and touchy, to shirk the disagreeable, to be untrustworthy and mean, to be troubled by few qualms of conscience.

For many details of Duroy's career comparisons are to be found in the lives of the secondary characters of Flaubert as well as in the experience of Frédéric. He is, as has been seen, rather like Cisy than Frédéric in the affair of the duel. He resembles the former also in his attempt to secure for a wife the young heiress of the financial magnate. Here a further parallel is found in Martinon, who actually does secure the heiress, outdoing the other suitor, like Duroy, by skilful manoeuvring. Both men transfer their attentions in the transaction to the young girl in question, the one from the mother, the other from the aunt, to the great chagrin of the older woman. ${ }^{30}$ Both, beginning in social obscurity, attain considerable prominence in the circles in which they move, owing largely to feminine favors. Like Flaubert's Hussonnet, Duroy shamelessly makes a convenience of people; like his Delmar, he exercises a strange fascination over

${ }^{21} L ' E d . S .$, pp. I3I, I40-4I, etc.; B.-A., p. 57.

22 L'Ed.S., p. 30, etc.; $B .-A$., pp. 52 ff.

${ }^{23} L$ L'Ed.S., pp. 139-40; B.-A., p. 530, etc.

24 L'Ed.S., pp. 24, 37, etc. ; $B$.-A., pp. 178-79, etc.

${ }^{25}$ L'Ed.S., p. 185; $B$.- $A$., pp. 180-81.

${ }^{26}$ L'Ed.S., pp. $342-44 ; B .-A$., pp. 184-85.

27 L'Ed.S., p. I62; B.-A., p. 28.

${ }^{28}$ L'Éd.S., pp. 7I, 323, etc. ; B.-A., pp. 29-3I, 5I, etc.

${ }^{29} L^{\prime} E$ d.S., pp. $530,536,552$, etc. ; B.-A., p. 428, etc.

30 The motif of a man's falling in love with the daughter after being the mother's lover is rather frequent in Maupassant. Cf. Fort comme la Mort, etc. 
others, owing partly to his appearance, with, as is hinted, its resemblance to the traditional ideal of benevolence. ${ }^{31}$ In some ways Duroy shows also considerable similarity to Deslauriers, Frédéric's friend. $\mathrm{He}$ is of the social class rather of Deslauriers than of Frédéric and appears at first, like him, in shabby clothing, borrowing money from a friend. Duroy's father is a "cabaretier"; the latest avocation of Deslauriers' father is the same. Both give the impression of possessing greater energy than Frédéric. Finally Deslauriers resembles Duroy in his journalistic interest.

In L'Education sentimentale and Bel-Ami there are, besides the characters already mentioned, others which correspond in certain details. In both books there are two men of affairs, one of whom is of much greater prominence than the other. Forestier is like Arnoux in his feverish activity, in his fondness for "bibelots," and in some other interests ; he is like Dambreuse, as has already been pointed out, in the manner of his death. Walter resembles Dambreuse in dominating the financial situation of the story and in exhibiting the self-importance and other characteristics of a financial magnate.

Among the women Mme Walter resembles Mme Dambreuse, as has been said, ${ }^{32}$ in being the "grande dame," in her relations with the principal character, and in her jealousy of the younger woman who takes her lover from her. In her puerilities she is like Rosanette rather than Mme Dambreuse. Her absurd infatuation for Duroy further resembles somewhat that of "La Vatnaz" for Delmar. The daughter of Mme Arnoux has already been referred to as having her counterpart in the child of Mme de Marelle. Both little girls are represented as acting like grown-up people and especially as displaying a coquetry in advance of their years.

Besides the similarities in specific incident already mentioned there are a few others which ought to be noted here. In both stories the chief character is annoyed by a "scie"-Frédéric by that of "Arnoux," Duroy by that of "Forestier." 33 In both there is a public ceremony in the Madeleine, characterized by irreverent behavior on the part of those present. ${ }^{34}$ In both a picture of the Founder of Christianity plays some part. ${ }^{35}$ In each some mention is made of the condition of French affairs in Algeria.

${ }^{31}$ L'Éd.S., pp. 103, 43I-33, etc.; B.-A., pp. 508, 55I, etc.

${ }^{32}$ See above, p. 68. ${ }^{33} L^{\prime} E$ E.S., p. 84, etc.; B.-A., p. 345, etc.

${ }^{34} L^{\prime} E d . S$., pp. $546-47 ; B .-A$., pp. 56r ff.

${ }^{35} L^{\prime} E d . S$., p. $429 ; B .-A$., pp. 478 ff. See below, p. 86. 
In addition to particular resemblances there is considerable likeness in general setting between $L^{\prime} E d u c a t i o n$ sentimentale and $\mathrm{Bel}$ $A m i$. Both give pictures of Parisian society of various grades and types, involving excursions, at all hours of the day and night, through all parts of Paris and into all manner of places of business and of legitimate and illegitimate pleasure. In both much space is allotted to the social happenings which illustrate the society in question-to balls, receptions, dinners, etc. In each the political events of the day are closely connected with the fortunes of the characters. Bel-Ami is in the main a story of journalism; L'Education sentimentale has likewise much to say of journals and journalists. Financial affairs of various kinds enter largely into the development of the plots. In social and business matters the atmosphere in the two books is one of scandal and deception, of intrigue, of sordid quarrelsomeness and undignified striving.

Besides the cases in which a whole story of Maupassant's corresponds to the whole or to part of a story of Flaubert's there are many instances of similar incidents and scenes. In Farce Normande ${ }^{36}$ there is described a wedding procession through the fields like that of Emma in Madame Bovary. ${ }^{37}$ There is the same order of procession and the same atmosphere of peasant gaiety. In Madame Bovary the cortège is called "une seule écharpe de couleur" ;38 in Farce Normande it is compared to a serpent. ${ }^{39}$ The people following Emma proceed to the accompaniment of a fiddler's efforts ; those in Farce Normande to the shots fired off in honor of the bridegroom, who is "un chasseur frénétique." ${ }_{40}$ The sounds of the fiddle, even when heard from a distance, frighten the little birds away. ${ }^{41}$ In Farce Normande the flaming shawls of the women have the same effect of astonishment upon the hens, the ducks, and the pigeons of the farmyard. ${ }^{42}$ A similar idea is found in Petit Soldat, ${ }^{43}$ where it is said that the shining leather shakos and copper buttons of the two "little soldiers" stop the larks overhead. ${ }^{44}$ After the procession there is in both stories the same lengthy feasting and the same free jesting, with a predilection

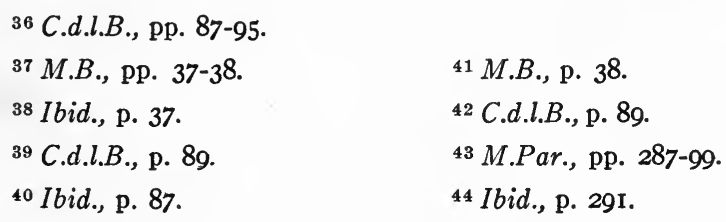


for practical jokes. ${ }^{45}$ In $M a F e m m e^{48}$ and $U n e V i e^{47}$ there is also mention of a Norman wedding feast and the succeeding rustic ball, the passages being almost precisely the same in the two places. A third procession across the fields, this time going and coming, instead of only coming as in the former stories, is described in $L e$ Baptême. ${ }^{48}$ In all three descriptions of processions attention is called to the playing of children round and about the moving company of their elders. The last-named procession is, like the preceding two, followed by a feast and rude joking. Other processions through the country are Emma's funeral procession in Madame Bovary, ${ }^{49}$ the procession to the shore at the christening of the "Jeanne" in Une $V i e,^{50}$ the procession of the sacrament to the house of the dying peasant woman in Le Diable, ${ }^{51}$ and the procession at the blessing of the springs in Mont-Oriol. ${ }^{52}$ Another ceremony in a peasant community which is depicted by both Flaubert and Maupassant is that of the first communion. Accounts are given of this in $U n$ Coeur simple, Bouvard et Pécuchet, and La Maison Tellier. ${ }^{53}$ In all three the veils of the little girls are described by means of very similar figures. In Un Coeur simple they are said to form "a field of snow" ;4 in Bouvard et Pécuchet the children kneeling resemble "a line of white clouds" ;5 in La Maison Tellier they are enveloped in "a cloud of snowy tulle." ${ }_{56}$ Maupassant's account of the ceremony is very much longer than either one of Flaubert's, and its satirical tone may well have been caught from Bouvard et Pécuchet. The midnight mass of Christmas Eve is also mentioned by the two men in Bouvard et Pécuchet, Un Réveillon, and Conte de Noël.57 Both speak of the coldness of the night (in all three stories), of the little lights in the darkness made by the lanterns of the peasants (in B.e.P. and C.d.N.), and of the scene of naive faith in the church (in all three stories). In Madame Bovary and in Mont-Oriol a public celebration ends with fireworks, the exhibition of which departs in each case

${ }^{45}$ M.B., pp. 38-41 ; C.d.l.B., pp. 90-95.

${ }^{49}$ M.B., pp. 465-66.

${ }^{46}$ L.M.T., pp. 265-76.

47 U.V., pp. 79-81.

${ }^{48}$ M.Har., pp. 245-53. 50 U.V., pp. 58-59.

${ }^{51}$ L.H., pp. 128-29.

52 M.-O., pp. 232-34.

${ }_{53}$ T.C., pp. 25-26; B.e.P., pp. 314-16; L.M.T., pp. 31-38.

54 T.C., p. 25.

${ }^{55}$ B.e.P., p. 315 .

${ }^{56}$ L.M.T., p. 30.

${ }^{57}$ B.e.P., pp. 297-98; Mlle F., pp. 173-75; C.d.L., pp. 67-70. 
somewhat from the prearranged plan. ${ }^{58}$ A small incident of a peasant assembly which is noticed by both authors is the following. In Madame Bovary, while the crowd in the street is listening to the speeches at the "Comices agricoles," there comes a gust of wind, and "tous les grands bonnets des paysannes se soulevèrent, comme des ailes de papillons blancs qui s'agitent." ${ }^{59}$ In Les Sabots, ${ }^{60}$ a similar gust of wind, blowing through the open doors of a church over the "bonnets blancs des paysannes," tosses up in its passage "les longs rubans des coiffures." ${ }^{61}$ In Le Rosier de Madame Husson ${ }^{62}$ there is a public address distinguished by something of the same inanity as is apparent in the speech of the counsellor at the "Comices agricoles." To be mentioned also in this connection are the account of the meeting of the club in L'Education sentimentale and of the suffrage society in Oeuvres posthumes, II. ${ }^{64}$ The audience consists in each case of ridiculous and ineffective figures, among them certain foreigners, the speeches are foolish, and the gathering is disorderly. The whole representation is evidently intended to be caricatural.

Several times both in Flaubert and in Maupassant it happens that a person in need of some kind goes to a church or to a priest for aid. L'histoire d'une fille de ferme ${ }^{65}$ resembles here in a short passage the experience of Emma Bovary. Emma, hearing the bell ringing the Angelus, and remembering her convent days, goes to the church, where she meets the Abbé Bournisien. To him she tries to tell her trouble, but, repulsed by his strange lack of comprehension, leaves him with her distress unspoken. ${ }^{66}$ Rose goes to church and prays at the time of the Angelus. Then she seeks out the curé; but he goes on with his dinner as he waits for her to speak, and she, like Emma, departs with her secret unrevealed. An incident in Bel-Ami which has several points of contact with one in Madame Bovary is that where Mme Walter gives Duroy a rendezvous in the Church of the Trinity. ${ }^{87}$ Similarly Emma has promised to meet Léon in Rouen Cathedral. ${ }^{68}$ Like details are noted in the scene outside of the church - the brightness of the summer sun and the plashing of the water in

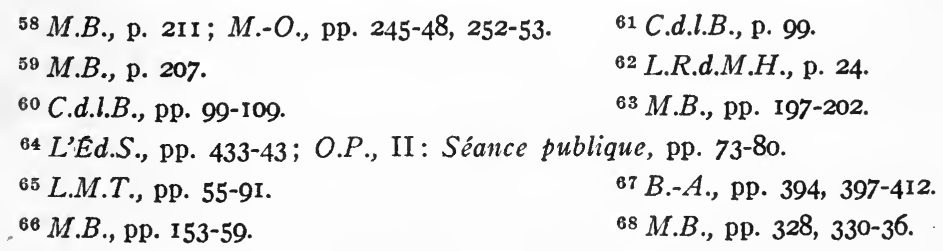


the fountain. In both cases the lover arrives too early and makes the circuit of the nave, noticing, among other things, the light falling through the colored windows. In both he becomes impatient and finally sits down to wait. Léon's solitude and subsequent meeting with Emma are disturbed by the "suisse," who wishes to exhibit the sights of the cathedral. Likewise Duroy's waiting and his rendezvous with Mme Walter are punctuated by the steps and by the words of "un gros monsieur," who also asks some questions regarding the historical monuments of the church. Duroy, like Frédéric, first becomes aware of the arrival of his mistress on hearing the rustle of her dress. Here the wording is very similar.

\section{Flaubert}

C'était elle. Léon se leva et courut à sa rencontre [M.B., p. 332].

\section{Maupassant}

C'était elle. Il se leva, s'avança vivement $[B .-A$., p. 400].

Both women try to break loose from temptation, Emma by means of a letter which she has written the previous evening and now hands to Léon, Mme Walter in words, as Duroy and she kneel side by side. Both subsequently attempt to obtain resolution in prayer, despairingly looking for supernatural aid. Both find their distress but increased by the atmosphere of the church. Mme Walter is delivered for the time being by the advent of a priest, whom she constrains to hear her confession. Emma gives way to Léon. Another scene in a church, this time between husband and wife, ${ }^{69}$ has nothing in common with the foregoing except the distress of the woman.

Additional places of rendezvous alluded to by both authors are: a carriage or diligence $;^{70}$ a specially prepared apartment $;^{71}$ the end of a garden ${ }^{72}$ (in $M . B$. and $B .-A$. an arbor) ; the public street $;^{73}$ a conservatory $;^{74}$ and so on. In Madame Bovary, Léon and Emma go on an excursion in a rowboat. A similar incident is found in Lettre trouvée sur un noyé. ${ }^{75}$ The following points are alike in both: the two dine

${ }^{69} L ' I . B .$, pp. 13-15.

${ }^{70}$ M.B., pp. $336-38 ;$ B.-A., pp. 128-29; L.R.d.M.H.: Un Echec, pp. 45-50; C.d.J.e.d.l.N.: L'Aveu, pp. 50-56; etc.

${ }^{71} L^{\prime} E d . S .$, pp. $396,407-8$; B.-A., pp. 140 ff., etc.; $N . C$. , pp. 112 ff.; etc.

${ }^{72}$ M.B., p. 234, etc.; L.S.R.: Le. Mal d'André, pp. 125-27; B.-A., pp. 497, 50 r.

${ }^{73}$ L'Ed.S., pp. 395, 397, 399-401 ; B.-A., pp. 540-4I ; N.C., p. I21.

${ }^{74}$ L'Ed.S., p. 176; B.-A., p. 496, etc. ; O.P., I : La Serre, pp. 147-54.

${ }^{75}$ O.P., I, 214-17. 
in an inn by the waterside; they embark in the darkness of evening; they skirt wooded shores; influenced by the moonlight, they indulge in sentimental thoughts and observations.

A situation that is found more than once in both authors is that of the desertion of a woman by her lover. There is considerable general resemblance in this connection between the stories of Félicité in Un Coeur simple and Rose in L'histoire d'une fille de ferme. ${ }^{78}$ Both are servants on a farm and go through the usual processes of peasant love-making. In each story promise of marriage has been given by the man, and the distress of the poor girl on being left is unusually keen. The likeness between the cases of Emma Bovary and Jeanne in Une Vie has already been mentioned. ${ }^{77}$ Another instance is that of Mme Walter, who is found unconscious the morning after hearing that her daughter has gone away with Du Roy. ${ }^{78}$

Two incidents in Madame Bovary have a long train of successors in the works of Maupassant. These are the finding of his wife's love letters by Charles after her death, ${ }^{79}$ and the examining of his souvenirs by Rodolphe. ${ }^{80}$ For a long time after Emma's death Charles does not open the secret compartment of her "bureau de palissandre." On doing so at last, he unearths the letters of Léon, those from Rodolphe being subsequently found in a box. He is thrown into wild despair by his discovery. In Une Vie, Jeanne, watching by her mother after the latter's death, takes the dead woman's letters from the drawer of the "secrétaire d'acajou" and reads them. Among them are letters from a lover, on the perusal of which she is shaken, like Charles, with a paroxysm of uncontrolled grief. A very similar instance is to be found in La Veillée, ${ }^{81}$ where a son and daughter, watching by a dead mother, take her letters from the drawer where they have been kept, and on reading them make, to their horror and amazement, a discovery like Jeanne's. In Nos Lettres ${ }^{82}$ the revelation comes to a stranger. Arriving for a visit at a friend's house, he is given the unoccupied room of the deceased "Tante Rose." There, on looking in the "secrétaire d'acajou" for writing materials, he finds a secret compartment, which he succeeds in opening. He reads the letters therein contained, which furnish evidence of a hitherto unsuspected love affair of the dead woman's. In Le Pardon ${ }^{83}$ a wife is

76 T.C., pp. 7-10; L.M.T., pp. 59-64.

77 See above, p. 65 .

78 B. $A$., pp. 552-53.

${ }^{79} M . B .$, pp. $478-79$.
80 Ibid., pp. $278-80$.

81 O.P., I, 55-60.

${ }^{82}$ C.d.L., pp. 208-16.

83 Ibid., pp. 92, 96. 
informed of her husband's treachery through an anonymous letter, and again through a note to him from his dying mistress, which she picks up and reads. In L'Ordonnance, ${ }^{84}$ a husband receives like news of his wife in a letter written by her just before she commits suicide and found by him on her work-table on his return from her funeral. Another letter from a suicide, composed during his last night and discovered next day on his table, narrates the causes of his selfdestruction-disillusionment, ennui, and the memory of the past brought back by souvenirs that he has preserved. ${ }^{85}$ Here might be mentioned the letter of Emma to Charles explaining the poisoning of herself. ${ }^{88}$ Letters taken from under a "prie-Dieu" in the Madeleine, according to Les Caresses ${ }^{87}$ have again to. do with a love intrigue. A variation in the medium of revelation occurs in $U n F o u^{88}$ and in Un Cas de divorce. ${ }^{89}$ In the former a journal discovered after his death in the secretary of an esteemed judge shows him to have been afflicted with homicidal mania and to have committed murders under its compulsion. In the latter the journal of the husband is quoted by the lawyer for the wife as proving "la folie poétique" on the part of the man, and consequent good reason for the granting of the divorce.

We come now to the second incident named at the beginning of the preceding paragraph, which is the examining of his souvenirs by Rodolphe. This he does after leaving Emma and before writing his letter of farewell to her. He has kept these souvenirs in an old biscuit-box and turns them about with callous indifference. ${ }^{90}$ A somewhat similar collection of souvenirs is enumerated by the suicide who has been spoken of above as having left a letter explaining his departure. ${ }^{91}$ Olivier Bertin also spends some time in going through his souvenirs of the countess ${ }^{92}$ - sorrowfully, like the "Suicide," not heartlessly, like Rodolphe. Sorrowfully also does "la baronne" inspect her "relics"93 - the "relics" which afterwards reveal her secret to her daughter. Jeanne herself, we are told, is preparing her "boite aux

84 L.M.G., pp. 96-101.

${ }^{85}$ L.S.R.: Suicides, pp. 229-39.

86 M.B., pp. 435-37.

${ }^{90} M . B$. ., p. 279.

${ }^{87}$ L.p.R., pp. $28 \mathrm{I}-88$.

${ }^{21}$ L.S.R.: Suicides, p. 237.

${ }^{88}$ M.Par., pp. 16i-73.

${ }^{2}$ F.c.l.M., pp. 295-96.

${ }^{89}$ L'I.B., pp. 218-29.

$93 U . V$., pp. $33,227-28$. 
reliques."94 The incriminating letters in La Veillée have also been "relics."95 Finally we have mention in Pierre et Jean of "le tiroir inconnu ou l'on serre les reliques d'amour." It will be noticed that the two incidents of the revealing letters and the souvenirs are combined in three of the cases cited from Maupassant-that of "la baronne" in Une Vie, that of the "Suicide," and that of the mother in La Veillée.

There still remain to be noted many incidents similar in the two writers. In L'Education sentimentale and Une Vie we have related a father's repugnance for his child, whom he kisses in each case under compulsion "du bout des lèvres." 97 The example of a man who, through idleness, devotes himself to a perfectly useless and foolish occupation is furnished in Madame Bovary by Binet, who spends all his spare moments in the fashioning of wooden napkin-rings. ${ }^{98}$ Maupassant has two characters who do similar things. Cachelin in $L^{\prime} H_{\text {éritage }}^{99}$ occupies his time after leaving the "bureau" in cutting out covers for cigar boxes with a "fine mechanical saw," which corresponds to Binet's lathe. Likewise Marowsko in Pierre et Jean spends much of his time in making "des sirops et des liqueurs," without succeeding in putting any on the market. ${ }^{100}$ The case of Regimbart in L'Education sentimentale is also that of one who spends his days in aimless idling. ${ }^{101}$ His time, when Frédéric comes to know him, is passed in going from one café to another, eating, drinking, reading the newspapers, or sitting in morose taciturnity until the proprietor turns him out, often after midnight. Towards the end of the book we find him in "un petit café sur la place de la Bastille, où il se tenait toute la journée, dans le coin de droite, au fond, ne bougeant pas plus que s'il avait fait partie de l'immeuble." There he sits, letting fall from time to time the word "Bock!" for he has reduced his speech to the indispensable. He resembles closely Maupassant's picture of a habitual "bockeur" in his story «Garçon, un Bock!» ${ }^{102}$ The "Bockeur" thus describes his life:

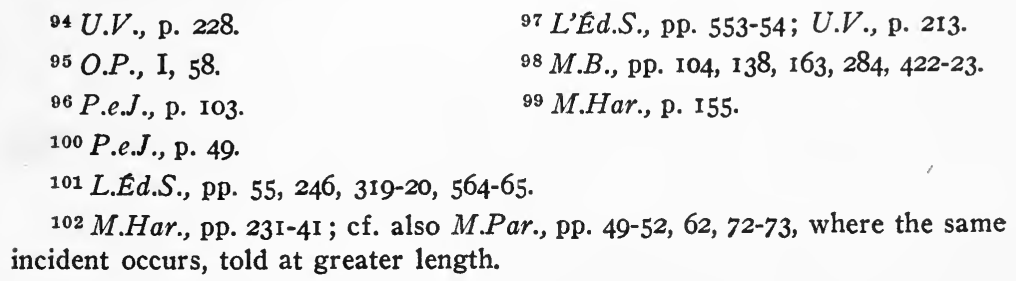


Je me lève à midi. Je viens ici, je déjeune, je bois des bocks, j'attends la nuit, je dine, je bois des bocks; puis, vers une heure et demie du matin, je retourne me coucher parce qu'on ferme. C'est ce qui m'embête le plus. Depuis dix ans, j'ai bien passé six années sur cette banquette, dans mon coin; et le reste dans mon lit, jamais ailleurs. Je cause quelquefois avec des habitués. ${ }^{103}$

All through the conversation which the "Bockeur" has with the other personage of the story he calls out constantly the words which form the title, «Garçon, un Bock!»-an exclamation not quite so laconic as Regimbart's "Bock!" At the end of the story he breaks his pipe and laments over the time it will take him to bring another to the same pitch of perfection. This recalls Dussardier, ${ }^{104}$ to whom happens the same accident, with the same regret following. Both Flaubert and Maupassant describe in varying terms places of entertainment which have in common the account they give of the motley crowd. ${ }^{105}$ An incident alluded to in each author is the following. Rosanette in L'Education sentimentale throws crumbs to the fish in the "étang des carpes" at Fontainebleau during her visit to the château with Frédéric. ${ }^{106}$ In his house Walter, in Bel-Ami, has a large pond, with small fountains, containing "quelques énormes poissons rouges," ${ }^{107}$ which are tame and come to the surface to be fed. ${ }^{108}$ Another animal instance is as follows. In Un Coeur simple, it will be remembered, there is a parrot which becomes the pet of Félicité, which is stuffed after its death, and which the simple woman comes to confuse in her thought with the representations she has seen of the Holy Spirit. ${ }^{109}$ In two of his tales Maupassant speaks of parrots. In Boitelle $^{110}$ he merely gives a description of the different brightcolored and noisy parrots exposed for sale on the quays at Havre. In Le Noyé $e^{111}$ he tells the story of a woman whose husband has been drowned after she has suffered years of abuse from him. She buys a parrot at a sale, but is so terrified on hearing it speak to her in the voice of her husband and in the words with which he had been wont

${ }^{103}$ M.Har., p. 235. ${ }^{104}$ L'Ếd.S., pp. 44-45.

${ }^{105}$ For example, L'Ed.S., pp. I63 ff.; Toine: L'Armoire, pp. I50-51 ; L'I.B.: Le Masque, pp. I59-75; B.-A., pp. I8 ff.; O.P., II : Essai d'Amour, pp. 57-58. ${ }^{106}$ L'Éd.S., p. 462. ${ }^{107}$ B.-A., p. 489.

108 B.-A., pp. 509, 510-11, 513, 514; cf. Sal., pp. 14-15; cf. also O.P., II: Un Diner et quelques idées, p. 63.

${ }^{109}$ T.C., pp. 40 ff.

${ }^{110}$ L.M.G., pp. 78-80.

111 L'I.B., pp. 119-33. 
to assail her, that she regards it as a re-embodiment of his spirit, kills it, and throws it into the sea, afterward praying to be forgiven for the crime she thinks she has committed. This story is like Un Coeur simple in the connection of the parrot with the supernatural.

In Madame Bovary, L'Education sentimentale, L'inutile Beauté and Fort comme la Mort are pictured scenes in theatres during a representation. ${ }^{112}$ All give some general descriptions of the crowd, of the movement, of the greetings and conversations there taking place. Those in Madame Bovary and in Fort comme la Mort are alike in some particulars. Emma in the one book, Olivier Bertin in the other, connect the music and the words of the opera with their own melancholy thoughts and are stirred by the strong love interest of the story.

Like Flaubert, Maupassant speaks not seldom of various forms of human malady. He gives, for instance, a description of a diphtheria case, as does Flaubert in L'Education sentimentale. ${ }^{113}$ One account of misfortune which has details of likeness to a passage in the works of the older man is that of "le père Clovis" in MontOriol. The old beggar, "cured" the year before by his daily baths in the waters of the Oriol spring, has become more incapacitated than ever, and laments his bad fortune in public to all who will listen to him. ${ }^{114}$ So also does the blind mendicant in Madame Bovary, whom Homais has tried, and failed, to cure. ${ }^{115}$ Andermatt in Mont-Oriol, like Homais, tries to have the beggar imprisoned. Unlike Homais he does not succeed in this, but he manages to silence old Clovis by other means. ${ }^{116}$

Several duels are depicted by the two authors. The points of resemblance between the duels of Frédéric and Duroy have already been considered. ${ }^{117}$ In L'Héritage ${ }^{118}$ a duel is threatened between Maze and Lesable, whom the former has insulted. As in Frédéric's duel, information has to be sought from authorities on certain technical matters. The occurrence is rendered ridiculous, like the duels of Frédéric and Duroy, even more so, in fact, in that the usual satisfaction is avoided through the signing by the principals of documents

112 M.B., pp. 307-16; L'Ed.S., pp. 126-27; L'I.B., pp. 22-34; F.c.l.M., pp. 317-32.

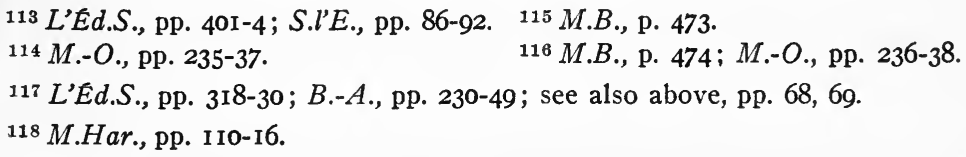


containing mutual excuses. In Un Lâche ${ }^{119}$ the "coward" of the story is involved in a duel, owing to an insult offered to a woman with whom he happens to be. As in the cases of Frédéric and Duroy his approval of himself is replaced by fear. Like them he looks in the glass and finds himself pale. His terror increases until it surpasses even that of Cisy in L'Education sentimentale. He finally commits suicide because he feels that he cannot face the ordeal. Un Duel relates a happening of a different kind. In it a Frenchman kills a German who has insulted him as a Frenchman after the defeat of 1870. The element of caricature, always present in these accounts of duels, is supplied here by the introduction of two Englishmen who act as seconds to the Frenchman, and by the fact that the victor has never before held a pistol, while his antagonist is an army officer. ${ }^{120}$

Another war story, Boule de Suif, introduces the hunger motif, which is found besides in Idylle and Le Vagabond, as well as in Salammbô. ${ }^{121}$ All emphasize the commanding, brutalizing power of hunger and the voracity of the hungry before the sight of food. In Le Vagabond also, as in Salammbô, are mentioned the dreams of food characteristic of a condition of starvation. ${ }^{122}$ Both Flaubert and Maupassant give an unpleasant picture of an old man, pitiable in his infirmity, who is a gourmand, and who shows his gourmandism by pointing or grasping helplessly at the dishes before him. ${ }^{123}$ The two writers also indulge their fondness for satire at the expense of the citizen-soldiers who make clumsy and ineffective efforts to rouse themselves from their corpulent sloth to the defence of their country. ${ }^{124}$ Two passages on this subject are somewhat alike.

Flaubert

Les uns, s'imaginant qu'il fallait beaucoup manger pour acquérir des forces, se gorgeaient, et d'autres. incommodés par leur corpulence, s'extenuaient de jeûnes pour se faire maigrir [Sal., p. 120].

\section{Maupassant}

Les gros n'allaient pas par les rues qu'au pas gymnastique pour fondre leur graisse et prolonger leur haleine, les faibles portaient des fardeaux pour fortifier leurs muscles [C.d.L.: U.C.d'E., pp. I5I6]. 120 O.P., I, 159-6r.

${ }^{119}$ C.d.J.e.d.l.N., pp. 107-21.

121 B.d.S., pp. 22-29, 75-76; M.Har., pp. 203-11 ; L.H., pp. 227-42; Sal., pp. 36I-68.

122 Sal., pp. 366-67; L.H.: L.V., p. 228.

${ }^{123}$ M.B., p. 68; L.H.: Une Famille, pp. 178-8r.

124 Sal., p. 120; C.d.L.: Un Coup d'état, pp. 15-16; Toine: Les Prisonniers, p. 18 r. 
Still another likeness to Salammbo is the mention, in Le Lapin, ${ }^{125}$ of the horses neighing towards the morning light, as do the sacred horses towards the sun in the former story.

Many passages in Flaubert and Maupassant give descriptions of death, of burial, and of the resting-places of the dead. ${ }^{126}$ In the nature of the case they have much in common. Scrutiny, however, fails to reveal any distinctive likenesses, resemblances being confined to the universal circumstances and concomitants of this human experience. Among the famous cemeteries described are those of PèreLachaise and Montmartre in Paris, and the "Cimetière des Capucins" near Palermo in Sicily. ${ }^{127}$ The frequency of such descriptions is to be connected with the thought of death entertained by the two authors. This has been referred to in a previous chapter. ${ }^{128}$ Frequent, likewise, are scenes on board passenger boats. ${ }^{129}$ All those cited mention the start of the boat, and all except $U n$ Echec and Une Vie speak of the bustle and noise on board. In Un Echec the man telling the story watches a woman on deck, as Frédéric does Mme Arnoux. The woman reads and smiles while reading, as Mme Arnoux is pictured doing. The man makes advances to her, like Frédéric, and is more successful therein than the latter. La Mer resembles the Flaubertian description in that the people take dinner during the passage.

Flaubert and Maupassant were both natives of Normandy and have left us numerous pictures of the Norman countryside (which both knew and loved), especially of that portion lying between Rouen and the sea. Each portrays the plains and the undulating stretches, with clumps of trees at intervals, the dusty highroads running like ribbons through the country, the farms protected by rows of poplars

125 Sal., p. 21 ; L.M.G., p. 106.

${ }^{128}$ For example, M.B., pp. 435-49, 453-69; L'Ed.S., pp. 537-50, 574-76, 58385; T.C.: U.C.S., pp. 37-38, 57-64; L.M.T.: En F., pp. 150-54, I67, 169-76; Les Tombales, pp. 251-57; C.d.l.B.: La Tombe, pp. 253-60; L.M.G.: L'Ordonnance, pp. 95-96, La Morte, pp. 22I-30; U.V., pp. 230-45, 246-47; B.-A., pp. 278-89; F.c.l.M., pp. 354-72.

${ }^{127}$ L'Éd S., pp. 548-49; L.M.T.: Les Tombales, pp. $251-54 ;$ L.V.e., pp. 69-76. 128 See above, p. 15.

${ }^{129}$ L'Ed.S., pp. I-II ; O.d.J., III, I80, 181-82; M.Har.: Mon Oncle Jules, pp. 276-84; M.Par.: Découverte, pp. 249-57; L.R.d.M.H.: Un Echec, pp. 37-44; U.V., pp. 93-98; P.e.J., pp. 231-37, 239-42; Au S.: La Mer, pp. 10-12. 
or beeches sheltering apple orchards and yards replete with lazy animal life, the fields gay with poppies and other flowers, the streams and ponds, the frequent roofs of thatch, the châteaux with their parks, the villages with their churches, cemeteries, inns, and "mairies," the lofty cliffs along the coast. ${ }^{130}$ One or two descriptions have more special points of likeness. For instance, the following paragraphs portray similar scenes in a somewhat similar manner.

\section{Flaubert}

Elle [la rivière] coulait sans bruit, rapide et froid à l'oeil; de grands herbes minces s'y courbaient ensemble, selon le courant qui les poussait, et comme des chevelures vertes abandonnées s'étalaient dans sa limpidité. Quelquefois, à la pointe des joncs ou sur la feuille des nénufars, un insecte à pattes fines marchait ou se posait. Le soleil traversait d'un rayon les petits globules bleus des ondes qui se succédaient en se crevant; les vieux saules ébranchés miraient dans l'eau leur écorce grise ; au delà, tout alentour, la prairie semblait vide $[M . B$., pp. I30-3I].

\section{Maupassant}

Il allait vite, le long de l'étroite rivière qui moussait, grognait, bouillonnait et filait dans son lit d'herbes, sous une voûte de saules. Les grosses pierres, arrêtant le cours, avaient autour d'elles un bourrelet d'eau, une sorte de cravate terminée en noeud d'écume. Par places, c'étaient des cascades d'un pied, souvent invisibles, qui faisaient, sous les feuilles, sous les lianes, sous un toit de verdure, un gros bruit colère et doux; puis plus loin, les berges s'élargissaient, on rencontrait un petit lac paisible où nageaient des truites parmi toute cette chevelure verte qui ondoie au fond des ruisseaux calmes [L.p.R., pp. 3-4].

Both passages here describe a little stream flowing along through the country by a village. In one case the stream is turbulent, in the other it is smooth. The general appearance of the river's course is the same in both, overshadowed by willows and fringed with reeds and long grass, to which the figure of "chevelure verte" is applied. A river placed similarly to that in Madame Bovary, washing the walls of the gardens on one side and bordered on the other by fields, is referred to in Notre Coeur. ${ }^{131}$ One or two pictures of farm ${ }^{130}$ For example, M.B., pp. 16-18, 46, 61-62, 65, 72, 95-100, 153; B.e.P., p. I10; L.M.T., pp. 23, 24-25: L'h.d'u.f.d.f., pp. 55-58, 76-77; B.d.S., p. 32 ; C.d.L., p. 9: Un Coup d'état, p. 21 ; M.Har, p. 7 ; L.P.R., pp. 3-4; U.V., pp. 23-26, 339-40, 344-45; O.P., I, 266; P.e.J., p. 19.

${ }^{131}$ N.C., p. 231. 
kitchens are alike in noting the reflection of sunlight or firelight in the bright kitchen utensils of various kinds. ${ }^{132}$ In three passages Maupassant describes the same view of Rouen as is indicated by Flaubert where Emma's gradual approach to the city from Yonville is retailed. ${ }^{133}$ All the pictures reproduce the outstanding features of the scene-the river, the church spires, the factory chimneys. Le Horla is further like Madame Bovary in mentioning the pleasant sound of the church bells on the early morning air. Maupassant more than once speaks of Croisset, Flaubert's home, ${ }^{134}$ besides describing in Le Horla ${ }^{135}$ a house and garden like his friend's, and mentioning in Boule de Suif the invasion of Rouen by the Prussians during which the Croisset house was occupied by them, as we know from the older man's correspondence. ${ }^{136}$ In the first Education sentimental $^{137}$ there is a picture of Havre resembling in some particulars that given in Pierre et Jean ${ }^{138}$ - through its mention of the throng of boats in the harbor, of the brightness of the lighthouses, of the greasy thickness of the fog. Flaubert has one, Maupassant four, descriptions of Mont-Saint-Michel. ${ }^{139}$

Besides living in Normandy, the two writers in question resided much in Paris, which both have described over and over again, Flaubert especially in L'Education sentimentale, and Maupassant in the many stories which have to do with the life of the metropolis. As may be expected, they often depict the same scenes, but again not with distinctive similarity. The greater frequency of night pictures in Maupassant is to be noted. ${ }^{140}$ One description several times repeated is that of the parade of carriages in the Champs-Elysées and the Bois de Boulogne. ${ }^{141}$ The reflection of the sun on parts of the

132 M.B., p. 18; B.e.P., p. 27 ; B.-A., pp. I93-94; O.P., I, 267.

133 M.B., pp. 363-64; C.d.l.B.: Un Normand, pp. I43-44; L.H., p. 4 ; B.-A., pp. 32I-23, 335 .

134 For example, B.d.S., p. 9; B.-A., p. 33I ; etc.

135 Pp. 3-4. 137 O.d.J., III, 179.

${ }^{136}$ Corr., IV, 44-59. ${ }_{138} \mathrm{Pp}$. 18, 21, 42, 93, etc.

139 P.l.C.e.p.l.G., pp. 310-17; C.d.L.: La Légende du Mont-Saint-Michel, pp. 103-4; L.H., pp. 10-II ; N.C., pp. 75-76, 94-105.

140 Cf. C.d.L.: La Nuit, pp. 219-28.

${ }^{141}$ L'Ed.S., pp. 33, 218, 298-99, 507-8; O.d.J., III, 4-5; Mlle F.: A Cheval, p. I59; C.d.J.e.d.l.N.: Le Père, pp. 38-39; Yvette: Promenade, pp. 206-7, 209, 2 I ; L'I.B., p. 5 ; B.-A., pp. 352-54, 359, 533; F.c.l.M., pp. 97-100, 104. 
carriages and harness is spoken of in L'Education sentimentale (p. 33) and in L'inutile Beauté (p. 5) ; the coming up of a cold wind on the promenaders in L'Education sentimentale (p. 298) and Fort comme la Mort (p. 99). There is an account of a visit to Fontainebleau in L'Education sentimentale (pp. 459-77) and in Notre Coeur (pp. $229 \mathrm{ff}$.). In addition to Normandy and Paris, both men have something to say about Brittany, Southern France, especially the Riviera, Corsica, Switzerland, Italy, and Algeria. ${ }^{142}$ In many cases the younger man seems to have followed the footsteps of the older in visiting these places, for the same, or almost the same, route will be outlined, and the same names will occur in the narrative. There is nothing to denote, however, that the one was influenced by the other in his descriptions of what both saw for themselves. Possibly there was an influence in the exciting of interest. This in turn may have caused a wish to see places already pictured in thought. Like Flaubert, Maupassant traveled in Brittany on foot. ${ }^{143}$ The part visited by both was the southern shore of the peninsula. ${ }^{144}$ Marseilles with its teeming life is portrayed by the two men. ${ }^{145}$ In Rome neither likes St. Peter's. ${ }^{146}$ Flaubert praises Michael Angelo's "Last Judgment," which Maupassant condemns. ${ }^{147}$ In La Vie errante, during the description of Tunis, Maupassant speaks of a ruined aqueduct near the town as "l'aqueduc de Carthage dont parle Flaubert dans Salammbô." 148

We have been considering hitherto for the most part descriptions of outdoor scenes; there are also many of various kinds of interiors, which likewise furnish few instances of striking similarity.

${ }^{142}$ See, for example, Flaubert's Par les Champs et par les grèves, Notes de voyages, and Correspondance; Maupassant's Au Soleil, Sur l'Eau, and La Vie errante.

${ }^{143}$ Maynial, La Vie et l'oeuvre de Maupassant, p. 183.

144 P.l.C.e.p.l.G.; cf. B.e.P., pp. 38 ff.; Corr., I, 283-85; C.d.l.B.: Un Fils, pp. 199-200; M.Par.: A Vendre, p. 100, Le Baptême, pp. 136-37, Petit Soldat, p. 288; L.P.R.: La Peur, pp. 274-75; L.R.d.M.H.: Une Soirée, p. I43; Au S.: En Bretagne, pp. 251-80.

${ }_{145}$ Corr., I, I53; III, 72; N.d.V., I, II-I2; II, 292-93, 345-46; L.M.G., pp. 202 ff. ; Au S., pp. 9-10, 183-84; P.l.C.e.p.l.G.: Pyrénées, p. 397.

${ }^{146}$ Corr., II, 66; B.d.S.: Corr., p. clvi.

${ }_{147}$ Corr., II, 56, 63; B.d.S.: Corr., pp. clv-vi.

148 L.V.E.: Tunis, p. 146; cf. Corr., III, 335-36, 346. 
Each writer gives a somewhat lengthy account of a factory. ${ }^{149}$ Two passages which have a number of like details are those portraying the "cabinets de toilette" of Rosanette and of Mme de Burne. ${ }^{150}$ Each room described is the centre of its owner's activities. The hangings of each are of "perse" or of "toiles de Perse." The furniture in both consists of restful seats, and of toilet tables and utensils, some of which in either case are of marble or crystal. In each there is a large looking-glass, and a bath curtained off from the rest of the room.

In treating the phenomena of the weather, of the seasons, of day and night, Flaubert and Maupassant are much alike. This is to be expected, as they deal with the same places and the same general climate. One or two instances of special emphasis or of similar turns of incident and expression are to be noted. Both describe days or nights of rain in Paris and in the country. ${ }^{151}$ Both speak of the "heavy heat" of summer. ${ }^{152}$ Each refers to the biting cold of the Norman or Parisian winter. ${ }^{153}$ The fog or mist of Normandy or Paris is also given its share of attention. ${ }^{154}$ Descriptions of sunrise and sunset and of moonrise and moonlight nights are frequent. ${ }^{155}$ In its rising the moon is sometimes represented by both men as appearing from behind trees. ${ }^{158}$

Many similar things are portrayed by the two authors. The "thing" may be a characteristic of personal appearance. Sometimes it is the direct glance of a character. ${ }^{157}$ Much space is given to the

${ }^{149}$ L'Ed.S., pp. 279-84;Au S.: Le Creusot, pp. 28I-89.

${ }^{150}$ L'Ed.S., p. 188; N.C., pp. 36-38.

${ }^{151}$ For example, L'Éd.S., pp. 152, 285, 297, 298-99, 510, 598; M.B., pp. 16, 167; U.V., pp. I-Io; Yvette, pp. 96-99; L.R.d.M.H.: L'Odyssée d'une fille, p. 207.

152 For example, M.B., p. 284; L.M.T., p. 39: En Famille, p. 137 ; C.d.l.B.: Les Sabots, p. 99; M.Har., p. 30; L.P.R., p. 43; S.l'E.: Livre de Bord, p. 198. 153 For example, M.B., pp. 88-89, 140, 294; L’Ed.S., pp. 82, 96; U.V., pp. 158-59; C.d.l.B.: La Folle, p. 4I, Saint-Antoine, p. 223. In the last two examples Maupassant speaks of the special cold of the winter of 1870 . N.C., pp. 185,195 .

154 For example, M.B., pp. 219-20; O.d.J., III, I79; L’Ed.S., pp. 96, 413; P.e.J., pp. 88-89, 93; L.M.T.: Sur l'eau, p. I9r.

155 For example, Sal., p. 21; M.B., pp. 223-24; Sal., pp. 55-56; M.B., pp. 354-55; C.d.J.e.d.l.N.: Un Lâche, p. II5; U.V., p. 379; U.V., pp. 70-71; C.d.L., pp. 8-10.

${ }^{158}$ For example, M.B., p. 274; F.c.l.M., p. 202.

${ }^{157}$ For example, M.B., p. 19; M.-O., pp. 7-8. 
description of hands-the gnarled and deformed hands of the worker, the "long, pale" hands of the man or woman of higher station, the soft, repulsive hands of an Arnoux or a Walter. ${ }^{158}$ Feet no less than hands are often alluded to and taken as symbolic. The broad, unwieldy boots of Charles Bovary seem to typify stupidity no less than the feet, "fort plats et fort gros," of Walter Schnaffs, the simple German soldier. ${ }^{159}$ The "gros souliers" of the peasants correspond to the character of the wearers no less than the dainty shoes of Emma or of Mme Arnoux. ${ }^{160}$ Mme de Marelle's diamond, which, held by a thread of gold, hangs from her ear, "comme une goutte d'eau qui aurait glissé sur la chair," suggests Salammbô's hollow pearls, filled with perfume, from which "de moment en moment, une gouttelette qui tombait mouillait son épaule nue." ${ }^{61}$ The likenesses between the diligence in Madame Bovary and that in La Bête à Maît' Belhomme have already been pointed out. ${ }^{162}$ In L'Aveu and Après the designation of a stagecoach as a "coffre jaune" is repeated. ${ }^{163}$ There are several enumerations of different kinds of carriages. ${ }^{164}$ Descriptions of pictures are common, including discussion of portraits of characters and of representations of Christ. ${ }^{165}$ Riches and their paraphernalia, such as "bibelots" of many kinds, occupy a considerable place in the works of both men. ${ }^{166}$

In Maupassant there is some use of names which have evidently a more or less close connection with names in Flaubert. The name "Le Poittevin," for instance, occurs several times, ${ }^{167}$ recalling the

${ }^{158}$ For example, M.B., pp. 208-9; L.H.: Le Diable, p. 127 ; L’Ed.S., p. 187 ; L.H.: Le Marquis de Fumerol, p. 97 ; L'Ed.S., p. 6r; B.-A., p. 50.

${ }_{159}$ M.B., p. 59; C.d.l.B.: L'Aventure de Walter Schnaffs, p. 235.

${ }^{160}$ For example, L.M.T.: L'h.d'u.f.d.f., p. 77 ; M.B., pp. 83, 109, etc.; L'Ed.S., p. II5.

${ }^{161}$ B.-A., p. 37 ; cf. also p. 43 ; Sal., p. 259.

${ }^{162}$ See above, pp. 58-59. $\quad{ }^{163}$ C.d.J.e.d.l.N., p. $52 ;$ O.P., I, 298.

${ }_{164}$ M.B., p. 35 ; L.M.T., p. 29; M.Har.: La Ficelle, p. 218 ; L'Ed.S., p. 298. ${ }^{165}$ For example, M.B., pp. 20, 326, 416; L.M.T., p. 5; Toine: L'Ami Patience, p. 29 ; B.-A., pp. 196 ff., 327 ; L'Ed.S., pp. 214 ff., 307-8, etc.; L'I.B.: Un Portrait, pp. 183-84; F.c.l.M., pp. I9 ff., 82 ff., 231 ff., 294 ff., II9 ff., 24 I ff.; $L^{\prime} E$ Ed.S., p. 429 ; B.-A., pp. 478 ff.; F.c.l.M., p. 14.

${ }^{166}$ For example, M.B., pp. 65-76; Sal., pp. 166 ff.; L'Ed.S., p. 27, etc.; L'I.B.: Qui sait?, p. 248; L.R.d.M.H.: La Baronne, pp. 87-95.

${ }^{167}$ For example, Mlle F.: L.V., p. 226; C.d.l.B.: N.d'u.V., p. 268; O.P., I: «Corr., p. 97. 
family friendship which was the beginning of the relationship between the two men. There are one or two souvenirs also of Flaubert's "Saint Antoine." In Maupassant's story of that title ${ }^{168}$ the name is applied to a Norman peasant, called Antoine, whose "cochon" is the Prussian soldier billeted upon him. Other mention of the same name in comparisons is found in La petite Roque (p. 44) and Bel-Ami (p. 316). The name "Polyte" is applied in L'Aveu to the driver of a diligence, in Le Lapin to the man-of-all-work on a farm, recalling the "Polyte" or "Hippolyte," "le garçon de l'auberge," in Madame Bovary. ${ }^{169}$ "Paul" in Un Coeur simple is the character corresponding to "Paul" in Une Vie. In L'Education sentimentale we hear of "la petite à M. Roque" (p. 13), and in Maupassant we have the story of "la petite Roque." Occasionally the names seem to be given with some special meaning in view. Thus an unfortunate woman is called Félicité, and a false lover, "Bel-Ami." Almost all the titles of Flaubert's novels are taken from the names of personages in the novels. Maupassant also uses largely the names of characters for the titles of his romans and contes. Where he does not the designation frequently lacks distinctiveness.

In characterization there is much similarity between the two authors. This has already been considered to some extent in connection with plots and incidents which depend in whole or in part on the characters of the personages involved, as is the case in $L^{\prime} E d u$ cation sentimentale for instance. Some additional resemblances will be treated here. Flaubert's best known character is probably Emma Bovary, of whom there are echoes in his subsequent work. 'Salammbô, for example, resembles her in her longings for the unattainable, Mlle Roque in her dissatisfaction with present circumstances. ${ }^{170}$ On comparing Flaubert and Maupassant we find that there exists a close likeness in character between Emma Bovary and Jeanne of Une $V i e$. There is also a marked contrast between them, which seems at times to be intentional on Maupassant's part, as if he had set Jeanne over against Emma designedly in order to emphasize the likeness between them by means of their differences. In some cases Jeanne's experiences suggest to one that they are planned so as to carry out Emma's imaginings.

${ }^{168}$ C.d.l.B., pp. 217-32.

${ }^{169}$ C.d.J.e.d.l.N., pp. 50 ff.; L.M.G., pp. 107 ff.

${ }^{170}$ L'Éd.S., p. 357. 
Both are educated in a convent at Rouen, the one entering at twelve and the other at thirteen, ${ }^{171}$ cut off from contact with ordinary human affairs and subjected to unnatural influences which tend to encourage an already too active sentimental imagination. Both spend much time at the convent in dreaming of love and leave its walls behind with extravagant hopes for the future and with an already confirmed habit of mind which influences all their future lives.

Each girl returns to her home in the country on leaving school. Jeanne has been kept by her father rigidly secluded from the world and is astonishingly ignorant of realities. In her outlook she is sentimental, if on the whole healthy-minded. Emma, while possessing a naiveté of a kind, is much more sophisticated than Jeanne in her knowledge of life, and her sentimentality shows already a morbid quality.

In the country Jeanne takes great delight, loving nature in all its aspects, and filled with the joy of living. To Emma the country is distasteful, for she knows it too intimately on its more sordid side, and the life there is wearisome and uninteresting. Both spend much time alone and indulge in that dreaming which is, throughout both books, the great similarity between the two characters. In both cases the dreams are full, first of expectations for the future, and then of regrets for the past. The effect of the dreaming is in each case the same-the separating of the dreamer from the actualities of life, and the begetting of unreal or extravagant ideas and expectations, of discontent or revolt.

In their dreamings the two women reveal the radical difference between their natures. Emma is fundamentally sensual; Jeanne is essentially pure. Emma, a typical example of the "femme incomprise et passionnee," fosters within herself notions of a grand passion like that of the heroines of whom she has read, "la légion lyrique de ces femmes adultères"; ${ }^{172}$ Jeanne dreams of a lover who is also a husband, of children, of a life of affection in the château with which most of her life has been connected and which is to be hers. Both exhibit certain delicacies in act and thought, springing in the one case from self-indulgence, in the other from innate pure-mindedness. Emma wishes for material luxury, for change, for something extraordinary to happen; Jeanne would be satisfied with "les simples bonheurs d'une existence calme." ${ }^{173}$ To both realization falls short

171 M.B., p. 48 ; U.V., p. $3 . \quad 172$ M.B., p. $225 . \quad 173$ U.V., p. 370. 
of imagination, and life brings repeated disenchantments alternating with periods of reviving hopes. Both come to curse "Providence" or "fate" for imagined injustice toward them, to regard the world as full of nothing but misery and deceit ; and to hate and despise mankind. In both cases the tendency to morbid reverie increases as time passes, being cherished instead of shaken off. In the end, however, the difference between the two is again brought out. Emma passes from our sight, as she dies with a hideous laugh of despair ; ${ }^{174}$ Jeanne with a revival of hope for the future of herself and those she loves, as she looks forward to her son's return home and holds in her arms that son's infant daughter. ${ }^{175}$

Closely associated with their sentimental dreaming is the nervous malady which besets the two women. Both are subject to attacks of "nerves," to fits of weeping, to "étourdissements," to "défaillances," to lack of will power, to periods almost of frenzy; Both are at times extraordinarily upset by the most insignificant things. Emma, however, retains all through a certain practical common sense which Jeanne almost entirely lacks.

The religion of both Emma and Jeanne is described partly as a habit left from their convent life, partly as connected with their romantic extravagances. The following characterization of Jeanne's religion might apply equally well to that of Emma: "La religion de Jeanne était toute de sentiment; elle avait cette foi rêveuse que garde toujours une femme; et si elle accomplissait à peu près ses devoirs, c'était surtout par habitude gardée du couvent. ... "176 The religion of Emma contains, besides, an element of sensuality ${ }^{177}$ which is absent from that of Jeanne. Both are represented as having violent paroxysms of religion, produced by circumstances, as well as the reactions from such paroxysms. Each turns to religion occasionally in times of stress, in either instance usually with little success.

In the conduct of life Emma sins, Jeanne is sinned against; the result is the same in the two cases-misery and deterioration. Both come, though for different reasons, to regard their husbands with repugnance. They learn to dissemble, Emma being urged thereto by a guilty conscience, Jeanne by pride, affection, or fear. In Emma this trait grows to alarming proportions. ${ }^{178}$ Jeanne is, toward the last, obsessed by a savage jealousy of her son's mistress. Emma is
$174 M . B .$, p. 449.
175 U.V., pp. $379-80$.
176 U.V., p. 262.
127 M.B., pp. $49,298,446$. See above, p. 18.
${ }^{178}$ M.B., p. 374. 
but an indifferent mother, her love for her child being spasmodic and sometimes a pose ; Jeanne is "une mère fanatique," erring thereby in the other direction. In personal appearance they are direct antitheses one of the other, Emma being dark and rather slight, Jeanne fair and vigorous-looking. ${ }^{179}$

In certain particulars, as has been said, Jeanne's experience seems to fulfil Emma's imaginings. Her voyage to Corsica is one example of this. Of Emma we read:

Elle songeait quelquefois que c'étaient là pourtant les plus beaux jours de sa vie, la lune de miel, comme on disait. Pour en goûter la douceur, il eût fallu, sans doute, s'en aller vers ces pays à noms sonores où les lendemains de mariage ont de plus suaves paresses! Dans des chaises de poste, sous des stores de soie bleue, on monte au pas des routes escarpées, écoutant la chanson du postillon qui se répète dans la montagne avec les clochettes des chèvres et le bruit sourd de la cascade. Quand le soleil se couche on respire au bord des golfes le parfum des citronniers; puis, le soir, sur la terrasse des villas, seuls et les doigts confondus, on regarde les étoiles en faisant des projets. Il lui semblait que certains lieux sur la terre devaient produire du bonheur, comme une plante particulière au sol et qui pousse mal toute autre part [M.B., p. $\left.5^{6}\right]$.

Allowing for the romanticism of the expression, the first part of this passage recalls Jeanne's wedding journey by the gulfs and through the mountains of Corsica, "ce long voyage au pas," past its "hauteurs escarpées." 180 It calls to mind also the emotions produced in her by her surroundings there, and her remembrance of these days in after years as among the happiest of her life.

Other examples of the fulfilment of Emma's dreams in Jeanne's experience are as follows. Emma hankers, as has been said, after the nobility; Jeanne is of noble rank. Emma would like to see Paris; Jeanne has visited Paris. Emma hopes to have a son; Jeanne's child is a son. Emma wishes that her husband were "beau, spirituel, distingué, attirant"; Julien possesses, at least at first, some of these attributes. ${ }^{181}$

More like Emma in some respects than her daughter is Jeanne's mother, "la baronne." She is addicted, like Emma, to the reading of

179 M.B., pp. 20, etc., 148, etc.; U.V., pp. 3-4.

180 U.V., pp. 93-113, 102.

${ }^{181}$ In all these details Maupassant seems to be working out suggestions caught from Flaubert. 
romantic fiction, such as that of Sir Walter Scott, ${ }^{182}$ to a consequent exaltation of passion as the main thing in life, and to an easy tolerance of amorous irregularities. She is fond of the nobility and much impressed with their importance. She has had a love intrigue in her past history, which is discovered, as is Emma's, after her death. through the medium of her letters. ${ }^{183}$

Other likenesses to Madame Bovary are numerous. Those in Une Aventure parisienne and Lia Parure have already been mentioned. ${ }^{184}$ In $M$. Jocaste ${ }^{185}$ we have an instance of disillusionment rather like Jeanne's than like Emma's, but attaching to Emma through that intermediary. Henriette in Monsieur Parent is like Emma in her detestation and consequent treatment of her husband. ${ }^{180}$ The following paragraph might describe almost equally well the Bovary situation:

Il avait épousé, quelques anneés plus tôt, une jeune femme aimée tendrement qui le traitait à présent avec une rudesse et une autorité de despote tout-puissant. Elle le gourmandait sans cesse pour tout ce qu'il faisait et pour tout ce qu'il ne faisait pas, lui reprochait aigrement ses moindres actes, ses habitudes, ses simples plaisirs, ses goûts, ses allures, ses gestes, la rondeur de sa ceinture et le son placide de sa voix. ${ }^{187}$

On one occasion Henriette says to her husband: "Tiens, tu ne seras jamais qu'une loque, un pauvre sire, un pauvre homme sans volonté, sans fermeté, sans énergie," just as Emma exclaims of Charles: "Quel pauvre homme! quel pauvre homme!"188 At another time she explains to her lover her reasons for detesting her husband, which might also be Emma's. First of all, he is her husband ; then he exasperates her constantly by his stupidity and slowness of comprehension.

There is further likeness to Emma to be found in Mont-Oriol. At first not much given to dreaming, ${ }^{189} \mathrm{Mme}$ Andermatt is brought through Brétigny's advances to perceive ecstasies not yet enjoyed and to long for them like Jeanne and Emma. ${ }^{190}$ When her dreams

182 See below, pp. 156-57.

183 See above, pp. 65, 75 .

184 Mlle F., pp. 193-205; C.d.J.e.d.l.N., pp. 59-74; see above, p. 66.

185 Mlle F., p. 260.

186 See especially pp. $5,22-30,35-38,42-43$.

${ }^{187} M . P a r .$, p. 5 ; cf. $M . B .$, pp. 57, 69, 77, 86, etc.

188 M.Par., p. 27 ; M.B., p. 86.

189 M.-O., p. 21.

190 M.-O., p. I39-40. 
are realized she exclaims: "Mais je l'aime ... je l'aime!" recalling by contrast Emma's "J'ai un amant! un amant!"191 In her thought at a subsequent period she repeats almost these words of Emma's, with a suggestion of the latter's delight at possessing "cette fièvre du bonheur."102 She thinks: "Aujourd'hui il était son amant! son amant! Donc elle avait un amant! Elle était sa maitresse!-sa maitresse! Elle répétait ce mot dans le secret de sa conscience-sa maitresse !"193

Mme Roland is another who is represented as having lived, like Emma, by the side of an uncongenial husband, cherishing dreams "de clairs de lune, de voyages, de baisers donnés dans l'ombre des soirs," and as having succumbed, like Emma, to the one who has brought to her that for which she has longed. ${ }^{194}$

The masculine counterpart of Emma Bovary, so far as dreaming goes, is Frédéric Moreau. At all stages of his career, until the very last, he resembles the youthful wanderer of $A$ Vendre, dreaming "à tout ce qu'on attend sans cesse, à tout ce qu'on désire, à la fortune, à la gloire, à la femme," ${ }^{195}$ with, perhaps, the order reversed. His propensity for reverie is closely associated with his other characteristic of ineffectiveness. It is also allied to his romantic feeling for Mme Arnoux, which dominates his whole life and extends even to everything connected with her. ${ }^{198}$ It is, however, rather Frédéric's incapability of action which is repeated in Maupassant. Brétigny, for instance, is said to be "incapable d'un effort continu." 197 An extreme example is found in Regret. ${ }^{198}$ This is the story of a man of sixty-two, who seems to himself to have lived a futile life. $\mathrm{He}$ reviews his existence as he looks out of the window at the falling rain:

Si encore sa vie avait été remplie! S'il avait fait quelque chose, s'il avait eu des aventures, de grands plaisirs, des succès, des satisfactions de toute sorte. Mais non, rien. Il n'avait rien fait, jamais rien que se lever, manger aux mêmes heures, et se coucher

Il n'avait même pas été aimé.

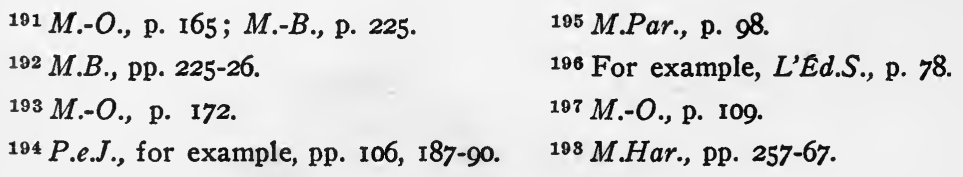


He thinks of a woman whom he had loved in the past, but whom he had lost through lack of the energy necessary to take advantage of an opportunity. A like indecision marks Renardet's efforts to kill himself after the commission of his crime. ${ }^{199}$ Another character resembling Frédéric both in his tardiness to act and in his dreaming is Pierre in Pierre et Jean. ${ }^{200}$ He has many times determined to make a fortune and has mused over what he will do with it but has taken no steps toward securing it by the time the novel comes to a close. $\mathrm{He}$ is contrasted here with his brother Jean, somewhat as Frédéric is compared with his friend Deslauriers. ${ }^{201}$ Mariolle, in Notre Coeur, is also one who suffers from failure to accomplish. ${ }^{202}$ The following words of his self-accusation might have been written also of Frédéric:

Il n'avait rien fait, rien réussi, rien obtenu, rien vaincu. Les arts l'ayant tenté, il ne trouva pas en lui le courage nécessaire pour se donner tout à fait à l'un d'eux, ni l'obstination persévérante qu'il faut pour y triompher. Aucun succès ne l'avait réjoui, aucun goût exalté pour une belle chose ne l'avait anobli et grandi. Son seul effort énergique pour conquérir un coeur de femme venait d'avorter comme le reste. Il n'était au fond qu'un raté. ${ }^{203}$

Of stupid husbands like Charles Bovary there are several in Maupassant. M. Parent has been already sufficiently characterized as such in the quoted words of his wife, Henriette. ${ }^{204}$ A similar case of deception by the wife is that in Le Petit, ${ }^{205}$ where the truth is not discovered until long after the woman's death. The husband there is described as "un bon homme, un brave homme, simple, tout simple, sincère, sans défiance et sans malice." ${ }^{206}$ Like Charles and like M. Parent at first, he loves his wife passionately, and like them too he annoys her by his awkwardnesses. The affection of each of the three for his child is an additional point of resemblance. M. Lantin, of Les Bijoux, ${ }^{207}$ is another character similar to Charles in his affection for and belief in his wife. Thrown into despair by her death, he imitates Charles in keeping her room intact and in spending there a

199 L.p.R., pp. 39-4I, 57-68.

200 P.e.J., for example, pp. 4-5, 53-55, 107-8.

201 P.e.J., for example, pp. 6, 53 ff., 89 ff., etc.; L'Ed.S., pp. 18 ff., etc.

202 N.C., pp. 205, 245-46.

205 C.d.J.e.d.l.N., pp. 199-208.

203 N.C., p. 205.

204 See above, p. 9 I.

208 Ibid., p. 199.

${ }^{207}$ C.d.L., pp. 139-52. 
part of each day. Even the garments of the wife are preserved by both. ${ }^{208}$

We turn now to another likeness in masculine characterization. Rodolphe, in Madame Bovary, is a type of the "predatory male" whose prey is woman. He has successors in Maupassant; Julien, in Une Vie, is one ; Paul Brétigny, in Mont-Oriol, is another. To both of these men may be applied equally well the description given of Rodolphe as "de tempérament brutal et d'intelligence perspicace." 209 All three show the expected cynicism in amorous affairs. Each makes advances to the woman of his pursuit for his own purposes; each soon tires of his conquest, being desirous of perpetual change in matters of the kind; each is careless of the blows he deals his victim. All three can lay claim to a certain elegance and power of attraction; all are possessed of some degree of wealth. Georges Duroy, of $\mathrm{Bel}-$ $A m i$, already described, ${ }^{210}$ would also belong to this class from certain of his characteristics.

In Maupassant, further, there are some traces of Homais and of the caricature of Voltairianism apparent frequently in the utterances of the "pharmacien." 211 The doctors in Mont-Oriol, for example, suggest him in their fussiness, their self-importance and exaggerated self-confidence, their ridiculous actions, and absurd, would-be learned pronouncements. ${ }^{212}$ So also does the doctor in Un Coup d'état ${ }^{213}$ through the same fussiness and self-importance, the same posing and fondness for elaborate language, as well as through his extreme desire for public glory. M. Sacrement, in Décoré, is, like the pharmacist, obsessed with a longing to be decorated, and writes pamphlets, as does Homais, in the hope of attracting the attention of the government. ${ }^{214}$ Like his prototype also he "does everything methodically." 215 On the opposite side of the medical situation from Homais are the cripples who appear in both authors. The "pied bot" of Hippolyte is repeated in the "Vénus Rustique" of Des Vers (p. I36) and in the story of Le Gueux. ${ }^{216}$ Another cripple with an important

208 Les Bijoux, p. 143; cf. M.B., pp. 471, 472-73.

209 M.B., p. $18 \mathrm{r}$.

$211 M . B$., for example, pp. 106-7, 213-14, etc.

210 See above, pp. 67 ff. 212 Cf. $M .-O .$, pp. 4, 14-15, 26 If., etc.

213 C.d.L., pp. 15-32.

214 L.S.R., pp. 243-53, esp. pp. 243-45; cf. M.B., pp. 187, 213, 477-78.

215 Page $25 \mathrm{I}$; cf., for example, M.B., pp. 23I-33, 340 ff., etc.

${ }^{216}$ C.d.J.e.d.l.N., p. 177. 
place in a plot is "le père Clovis," of Mont-Oriol, who "drags his right leg" (p. 8I ). Some souvenirs of Hippolyte also attach to the hideous inn servant of Un Fils. ${ }^{217} \mathrm{He}$ is thus described when first seen: "Il venait maintenant de puiser de l'eau pour les chevaux et portait ses deux seaux en boitant, avec un effort douloureux de la jambe plus courte." 218 One is at once reminded of Hippolyte as he goes limping about his business at the Lion d'or or through the village. ${ }^{210}$

Besides the inn servants, others belonging to the class of dependents suggest similarity. In Madame Bovary there is an old seamstress who comes to the convent where Emma is at school and entertains the girls with her tales of gallantry. Clochette is the account of a similar old seamstress, whose visits are among the childish memories of the spokesman in the conte. She frequents his father's house and tells him stories while she sews. ${ }^{220}$

Love for children and the influence of childhood occupy attention both in Flaubert and in Maupassant. Emma Bovary is recalled from the orgy of the masqued ball by the thought of Bertha sleeping at home. ${ }^{221}$ Charles Bovary is redeemed at times from his unattractiveness by his affection for his child. ${ }^{222}$ A similar redeeming affection is exhibited by Rosanette in L'Education sentimentale ${ }^{223}$ and by more than one of the outcast or unfortunate women in Maupassant's stories. $^{224}$ Numerous other instances of this sentiment can be found. ${ }^{225}$ The other side of childhood-the cruelty of the young animal-is likewise represented by the two authors. We have the schoolboys tormenting the awkward, shy boy at the beginning of Madame Bovary and torturing the poor little lad in Le Papa de Simon..$^{226}$

Most of the resemblances just discussed have to do with Madame Bovary; there are also a few associated with Salammbô. There is a certain similarity between the upbringing and outlook of Salammbô and Jeanne. Both have been kept by their fathers shut up from contact with the world and come to meet it in consequence with greater

217 C.d.l.B., pp. $205-13$.

218 Un Fils, p. 205.

221 M.B., p. 403.

${ }^{223}$ For example, pp. 555-56, 574 ff.

${ }^{224}$ For example, B.d.S., p. 56; L.M.T., pp. 27-28: L'h.d'u.f.d.f., pp. 68 ff.

${ }^{225}$ For example, M. Parent, etc. ${ }^{226} L M . T$., pp. Ir9-34.
219 For example, M.B., pp. 195, 262.

220 L.H., pp. 8r-82.

${ }^{222}$ For example, M.B., pp. 270-71, 473. 
or less ignorance of its ways. ${ }^{227}$ A second detail of likeness to Salammbô found in Maupassant bears witness rather to Flaubert's exact reproduction of unchanging African life ${ }^{228}$ than to any close literary relationship between the two authors. When we first see the Carthaginian maiden we are given a picture of her lofty headdress and of the abundant jewelry with which she is adorned. In his account of the Province of Algiers, Maupassant depicts the dress of the "Oulad-Nail," which includes also a "monumental" coiffure and many jewels. The corresponding passages are as follows:

Flaubert

Sa chevelure, poudrée d'un sable violet, et réunie en forme de tour selon la mode des vierges chananéennes, la faisait paraitre plus grande. Des tresses de perles attachées à ses tempes descendaient jusqu'aux coins de sa bouche, rose comme une grenade entr' ouverte. Il y avait sur sa poitrine un assemblage de pierres lumineuses, imitant par leur bigarrure les écailles d'une murène. Ses bras, garnis de diamants, sortaient nus de sa tunique sans manches ... [Sal., p. I4].

\section{Maupassant}

... une femme apparait, debout sur une porte, avec une large coiffure qui semble d'origine assyrienne, surmontée d'un énorme diadème d'or.

... avec ... leurs hautes coiffures à diadèmes qui rappellent les bas-reliefs egyptiens, les OuladNail attendent. ...

Puis en voici d'autres, avec la même coiffure monumentale: une montagne carrée qui laisse pendre de chaque côté une grande tresse tombant jusqu'au bas de l'oreille, puis relevée en arrière pour se perdre de nouveau dans la masse opaque des cheveux. Elles portent toujours des diadèmes dont quelques-uns sont fort riches. La poitrine est noyée sous les colliers, les médailles, les lourds bijoux; et deux fortes chainettes d'argent font tomber jusqu'au bas-ventre une grosse serrure de même métal, curieusement ciselée à jour et dont la clef pend au bout d'une autre chaine [Au.S.: La Province d'Alger, pp. 64, 66, 64].

227 Sal., p. 61 ; U.V., p. 3.

${ }^{228}$ Cf. L. Bertrand, "Le Cinquantenaire de Salammbô," R.D.M., (June I, 1912), esp. pp. 594-95. 
In the preceding paragraphs, as will be observed, there is a general impression of resemblance in the costumes described. The points of similarity which produce this effect are the towering Eastern headdress, with its pendent "tresses," in the one case of pearls, in the other of hair, and the breast smothered in jewelry of curious design.

In La Légende de Saint Julien l'Hospitalier we have the picture of a "mighty hunter." In Maupassant there are two classes of persons that descend from him: the first includes those who are animated by a ferocious but legitimate passion for the chase; the second, those who are impelled by an abnormal and criminal desire to see blood, to kill. These two passions, it will be remembered, are united in Saint Julien. To the first class belong the heroes of Maupassant's numerous hunting stories, who will endure all kinds of hardships and brave all manner of difficulties in order to indulge in their favorite pastime $; 229$ to the second division are to be assigned such types as "Moiron," who slaughters as vengeance for the loss of his own children the pupils intrusted to his care, and "Un Fou," who destroys for the mere pleasure of shedding blood, of taking life. ${ }^{230}$

The pictures of the clergy presented by the two writers in question have many points in common. For example, one of the characteristics of the Abbé Bournisien's appearance is the array of spots on the front of his cassock. ${ }^{231}$ This peculiarity is frequently repeated in the case of Maupassant's curés. ${ }^{232}$ Other inelegant personal attributes are likely to be accredited to priests. ${ }^{233}$ The Abbé Picot in Une Vie, like the Abbe Bournisien in Madame Bovary, is the typical easy-going curé, not too far removed in feeling from his parishioners, doing his duty as he sees it, with considerable insight into the ordinary human nature about him but slow to understand anything different from it. ${ }^{234}$ The type is repeated not infrequently in Maupassant. ${ }^{235}$ The opposite type, that of the fanatical priest, is represented by the Abbé Bournisien in his later years, the Abbé Marignan, etc. ${ }^{236}$

223 For example, Contes de la Bécasse; etc.

${ }^{230}$ C.d.L., pp. 195-204; M.Par., pp. I6r-73; etc.

231 M.B., p. 156.

232 For example, U.V., p. $35 ;$ L.M.T.: L'h.d'u.f.d.f., p. 86.

${ }^{233}$ For example, M.B., p. 156; U.V., pp. 35, 173.

${ }_{234} M . B .$, pp. I56-58; U.V., p. $253 . \quad{ }^{235}$ For example, B.-A., pp. 273-76.

${ }^{236} M . B .$, p. 476 ; U.V., pp. 260 ff. ; C.d.L., pp. 3-12. 
There are one or two other special details of similarity between a certain priest in Flaubert and a certain priest in Maupassant. The Abbé Bournisien, for instance, tells of being sent for to cure a cow ;237 the Abbé Tolbiac is thought to have special powers in this direction. ${ }^{238}$ The Abbe Bournisien is respected all the more on account of his athletic frame; the Abbé Vilbois is honored because he is the most muscular man in the district. ${ }^{239}$ A phrase applied by both writers to members of the clergy when speaking scornfully of them is "l'homme à la soutane" or "l'homme en soutane." ${ }^{40}$ The representation of the clergy in Maupassant tends to become caricatural, as do his portrayals of the English ${ }^{241}$ and of unmarried women of a certain age. ${ }^{242}$

In Maupassant's Sur l'Eau we read the following words: "C'est une foule, et cette foule est quelqu'un, un vaste individu collectif, aussi distinct d'une autre foule qu'un homme est distinct d'un autre homme."243 This characterization is worked out by both Flaubert and Maupassant in their numerous descriptions of crowds. Contrast, for example, the throng at the "Comices agricoles" of Madame Bovary with the numerous street gatherings of L'Education sentimentale; or compare the peasant crowd in La Ficelle with the assembly round and in the Madeleine at the end of $\mathrm{Bel}-\mathrm{Ami} \mathrm{i}^{244}$ Both note the strange impulsion that sways a crowd-what Flaubert calls "le magnétisme des foules enthousiastes." ${ }^{445}$ The idea of the accumulated effect of the multitude's "bêtise" is also expressed by both. ${ }^{246}$ One effect apparent in glancing over a crowd is noted by the two men in somewhat the same words. In both instances it is a peasant gathering that is being described.

FLAUBERT

... et, sur la longue ondulation de tous ces corps tassés, on voyait se lever au vent, comme un flot, quelque

\section{Maupassant}

Les cornes des boeufs, les hauts chapeaux à longs poils des paysans riches et les coiffes des paysannes

238 U.V., pp. 290-9r.

${ }^{237} M . B .$, p. 157.

${ }^{239}$ M.B., for example, p. 105 ; L'I.B.: Le Champ d'Oliviers, p. 49.

240 B.e.P., p. 324 ; U.V., p. 274 ; B.d.S., p. 30.

${ }^{241}$ For example, Toine: Nos Anglais, pp. 203-16.

242 For example, Miss Harriet; and Tante Lison in Une Vie.

243 Page 108.

244 M.B., pp. 183-214; L'Ed.S., for example, pp. 38 ff., 397 ff., etc.; M.Har., pp. $215-18 ; B .-A$., pp. 572-73.

${ }^{245}$ L'Ed.S., p. 420 ; cf.S.l'E., p. 109. 248 B.e.P., p. 209 ; S.l.E., pp. I10-I I. 
crinière blanche, ou saillir des émergeaient à la surface de l'assemcornes aiguës, et des têtes d'hommes blée [M.Har.: La Ficelle, p. 216]. qui couraient [M.B., pp. 190-9I].

Again, as often, the resemblance here is one of general impression, with fairly close likeness of details-the great sea of men's and animals' heads, with here and there one rising above the ordinary mass.

In the preceding paragraph we spoke more than once of rustic gatherings. In both authors we have representations of the peasant and fisher classes of Normandy and Brittany. In different individuals we have the varying and even contradictory characteristics of these classes clearly brought out-deep, enduring, but often inarticulate, affection, faithfulness, calm acquaintance with and acceptance of the facts of life, shrewdness, cautiousness, keenness in money matters, simplicity no less than trickery, mental limitation, superstition, stolidity, brutality, roughness and coarseness, low ideals of morality, fondness for pleasures of the table and for "farces."247 Special emphasis is given to the shrewdness of the Norman and to the superstition of the Breton. Both men observe the nearness of the peasant in certain aspects to the brute. Each says something of peasant costume and appearance. They refer also, on the one hand, to the strong frame of the country man or woman and, on the other, to the deformation of that frame through constant and brutal manual toil. ${ }^{248}$

In previous chapters there have been considered the ideas definitely enunciated by the two men regarding life in general and literary procedure in particular, as well as the exemplification of these ideas in practice. In the following pages will be treated other ideas similar in the two but not included by them in their explicitly pronounced theories.

There is, first of all, the thought of the salutary effect of ordinary things. Emma, coming home in the diligence after her unsuccessful attempt to get money in Rouen, is turned from the poignancy of her trouble by the spectacle of the well-known objects along the way. ${ }^{249}$ Jeanne is roused from apathy to new feeling as she holds in her arms

${ }^{247}$ For example, M.B., pp. 18, 27-28, 32-33, 35-42, 72, 190 ff., 208-9, 237-39, 249, 461-63, 467-69; U.C.S.; B.e.P., pp. 27-28, 37, etc.; Maupassant's numerous peasant stories and the peasants in U.V., B.-A., N.C.

248 Ibid. 249 M.B., p. 415. 
her infant grandchild. ${ }^{250}$ The dreams of a father or mother over the future of a child are to be found recorded in Madame Bovary, L'Education sentimentale, Une Vie, and elsewhere. ${ }^{251}$ The emotional action of music is noted several times. ${ }^{252}$ The connection of moonlight with love-making is frequently emphasized, as is the more general idea, of which this is a part, that love needs special places and circumstances for its development. ${ }^{253}$ The thought that lovenot always a very high type of that passion-is the only good thing in life is expressed by both writers..$^{254}$

Dreams of foreign countries and the longing to travel therein have been already alluded to several times as described frequently by both men. ${ }^{255}$ Usually the dreams contain more or less of what Maupassant calls "la vieille poésie des enlèvements nocturnes, des chaises de poste, des auberges, toutes les charmantes aventures des livres."256 The countries themselves, even if they happen to bear such ordinary names as "Italy" or "Corsica," are frequently pictured as "les pays bleus, les pays roses, les pays invraisemblables et merveilleux, introuvables et toujours cherchés qui nous font juger médiocres tous les autres." ${ }^{257}$ In $\mathrm{Bel}-\mathrm{Ami}$ there is a comparison derived from this longing for the unattainable: “Il n'avait jamais songé aux filles de son directeur que comme on songe aux pays lointains qu'on ne verra jamais." 258

In Flaubert's Correspondance $(\mathrm{I}, \mathrm{I} 58)$ there is a short sentence which suggests a much longer passage in Maupassant, ${ }^{250}$ the medium of communication here being probably discussion of the same sub-

250 U.V., p. 379.

${ }^{251}$ M.B., pp. 7-8, 270-71; L'Ed.S., p. 584; U.V., p. 229; Sal., p. 6r.

${ }^{252}$ For example, M.B., pp. 70, 309, 310-II ; L’Ed.S., pp. 8, 69;F.c.l.M., pp. 32I-32, 26r ff.; N.C., pp. r38-40.

${ }^{253}$ For example, M.B., pp. 60, 274-76, 354-56; C.d.L., pp. 3-12; L.p.R.: Julie Romain, pp. 215-18; U.V., pp. 70-73; M.B., p. 82; U.V., pp. 107 ff.

${ }^{254}$ For example, L'Ed.S., pp. 604, 612; L.P.R.: Mlle Perle, p. 141, Julie Romain, pp. 2ro ff.; B.-A., p. 123.

${ }^{255}$ For example, $M . B .$, pp. 56-57, 71, I12-13, 271-72; L’Ed.S., pp. 97, 133, 245, 360, 365, 469, 584; Corr., II, 59, 63; Des Vers: Une Conquête, p. 21 ; L.S.R., p. 3; U.V., pp. 53-54, 363; B.-A., p. $540 ;$; .-O., p. I50; P.e.J., pp. 45, 108; $A$ u S.: Préface, p. 5; S.l'E., pp. 92 ff.

${ }^{256} B$.- $A$., p. $537 . \quad{ }^{257}$ M.-O., p. I13; cf. M.B., pp. 56, 27I. $\quad 258$ Page 196.

${ }^{259}$ L.V.E.: La Côte Italienne, pp. 36-39. The palaces mentioned are those of Genoa. 
ject by the two men. The sentence is as follows: "Quand on a visité ses palais, on a une telle pitié du luxe moderne qu'on est tenté de loger à l'écurie et de sortir en blouse." The passage in Maupassant, which is too long to quote, contrasts the artistic dignity of the same old palaces with the banality of the modern millionaire's Parisian mansion. The idea of the unpleasantness of hotels is likewise voiced by both men. ${ }^{260}$ The thought of America as a far-away country from which one does not return is present in Un Coeur simple and Une Vie. ${ }^{261}$

Paris, in the mind of the provincial, according to Flaubert and Maupassant, takes on one of two aspects. Either it is a haven of all the delights, as it presents itself, for example, to Emma Bovary and to the little provincial of Une Aventure parisienne; or it is a place of danger, temptation, and iniquity, as it appears to Homais, to the lawyer in Une Vie, to the frightened old peasants in La Maison Tellier. ${ }^{262}$

Contrary to desire for the city is longing for the country when in the city. We find it entertained, for instance, by Charles Bovary and by Duroy, both of whom look out over the country and think how pleasant it must be there. ${ }^{263}$ The instructions of country life for those living in its midst are noted several times. ${ }^{264}$. Both authors suggest also the direct action upon man of external phenomena. ${ }^{265}$ The contrast between human circumstances and the aspect of outside nature is emphasized very strikingly upon occasion. As Charles, for example, walks to Emma's funeral, the appearance of the countryside is one of unusual brightness and beauty. ${ }^{268}$ As Jeanne watches by her dead mother the night is one of the loveliest of an unusually fine summer ${ }^{287}$ The romantic idea of the sympathy of nature with man-the "pathetic fallacy"-is rather common in Maupassant. In Une Vie, for instance, the weather all through may be taken as symbolical of the fortunes of the characters ; in L'Ivrogne, ${ }^{268}$ the howling

260 O.d.J., III, 2 ; L.S.R., pp. 5 ff.

261 T.C., p. 30 ; U.V., p. 366 ; cf. O.d.J., III, I67 ff.

262 M.B., pp. 80-82; Mlle F., pp. 193 ff.; M.B., pp. 168-69; U.V., p. 350;

L.M.T., p. 21 .

263 M.B., p. II ; B.-A., p. 60.

${ }^{264}$ For example, T.C.: U.C.S., p. 9; L.R.d.M.H.: L'O.d'u.F., p. 212.

${ }^{265}$ L'Ed.S., p. 458 ; U.V., p. 370.

267 U.V., pp. 235-37.

266 M.B., p. 466.

${ }^{268}$ C.d.J.e.d.l.N., pp. 125-34. 
storm corresponds to the terrible deed of the drunken man; in $L a$ petite Roque, the falling leaves are said to be the tears of the trees over the ending of the year and "perhaps" over the murdered child. ${ }^{260}$ There are traces also of this thought in Flaubert; for example, where the clouds pile up and the rain falls as Emma looks out of the window after Léon's departure from Yonville. ${ }^{270}$ In general, however, the treatment of nature in Flaubert is more or less detached from the circumstances of the story. ${ }^{271}$

The "pathetic fallacy" is not the only form of romanticism to be found in the authors in question. Romanticism appears, for instance, in their expressed longings, already often noted, to flee from burdensome reality toward the distant, the unattainable. This attitude is embodied for Flaubert in Salammbô, in La Légende de Saint Julien l'Hospitalier, and in Hérodias; for Maupassant in Le Horla and in other weird stories of the supernatural. There is besides in Flaubert a certain all-pervading sense of the mysterious, due at least in part to the vagueness produced by his superabundance of detail, which has often the effect exactly opposite to that of the exactitude intended. Corresponding in some sort to this in Maupassant is the weirdness already alluded to.

Romantic thoughts of love, of foreign countries, of Paris, of the future, etc., uttered by characters like Emma Bovary, Léon, Jeanne, and Paul Brétigny, have also already been discussed. Such ideas are continually being traced to the reading of romantic writers, especially of Sir Walter Scott, whose name occurs frequently in both authors in this connection. ${ }^{272}$ In thus linking thoughts which are represented as having, for the most part, pernicious consequences with the names of romantic writers both Flaubert and Maupassant make a certain attack on romanticism. One might also call romantic in a sense the extreme, even grotesque, caricature of Bouvard et Pécuchet and of many of Maupassant's stories. ${ }^{273}$

A kind of resemblance observable sometimes between Flaubert and Maupassant is that in which an idea of the older man's is taken

269 L.p.K., p. 33. 270 M.B.,'p. 167.

271 For example, the general treatment of nature in Madame Bovary.

272 For example, M.B., pp. 48-53; L'Ed.S., pp. I9, 21-22, 25, etc.; U.V., p. 33; P.e.J., p. I3; O.P., II : L'Angélus, p. 188.

273 Compare on the subject of romanticism in Maupassant the article by Olin H. Moore on "The Romanticism of Guy de Maupassant" in P.M.L.A. (March, 1918), pp. 96-134. 
up and expanded or given concrete reality by the younger. Some of the passages used in illustration of other points might apply equally well here. For instance, when Jeanne goes to Corsica, she travels somewhat as Emma would have liked to travel, sees in part what Emma would have liked to see, and finds there some of the transports which Emma thinks she might have experienced in another country. ${ }^{274}$ The stories of Le Bonheur and Julie Romain ${ }^{275}$ also realize certain of the details of Emma's love longings. Emma, we are told on one occasion, would have made confidences to the pendulum of her clock ; Jeanne practically does so. ${ }^{276}$ In L'Education sentimentale (p. 466) there is a description of oak trees in which they are spoken of as embracing. This idea is considerably expanded by Maupassant in Notre Coeur (p. 278), where the trees that embrace are, however, not oaks. In L'Education sentimentale, again, during the watch after the death of M. Dambreuse the carts are heard rumbling by to the market. Maupassant describes such carts as they go past under the street lamps, the light bringing out the colors of the different vegetables with which they are loaded. ${ }^{277}$

There yet remains to be considered a type of similarity which has already been illustrated to a large extent in discussing other points - similarity in wording. Additional examples of this will be given here. First of all, there are scattered here and there throughout the works of Maupassant phrases which, while not corresponding definitely to any particular phrases of Flaubert's, have yet in their composition a certain Flaubertian suggestion. Some examples follow:

"Chicot ... avait l'air d'un bifteck cru caché dans un bonnet de sapeur ..." [M.Har.: L'Ane, p. 187].

"Ces dames plus chamarrées que les chasubles des chantres" [L.M.T., p. 3I].

"L'étrange sympathie des émotions poignantes" [L.M.T., pp. 34-35].

"Il présentait un magnifique échantillon de la goujaterie naturelle au militaire victorieux" [B.d.S., p. 48$]$.

"Le jardin fleuri des polissonneries distinguées" [B.-A., p. I25].

"Un Niagara de barbe" [O.P., II, p. 37].

${ }^{274} U . V$., pp. 93 ff.; cf. M.B., pp. 56, 27 I.

${ }^{275}$ C.d.J.e.d.l.N., pp. 77-87; L.P.R., pp. 203-18.

${ }^{276} M . B .$, p. $86 ; U . V$., pp. 55 , 123.

${ }^{277}$ L'Ed.S., p. 543; C.d.L.: La Nuit, p. 223. 
Picturesqueness of expression tending to grotesqueness, the use of alliteration, and a general rhythmic effect are the characteristics of these quotations, which remind us of the type of phrase with which we have become very familiar in Madame Bovary. ${ }^{278}$ The exclamation "Grrrrande surprise" recalls one of Flaubert's methods of emphasis in his Correspondance. ${ }^{279}$

Exclamations of regret for the past on the part of romantic dreamers are frequent and much alike in the two authors.

Flaubert

Comme c'était vieux tout cela! [M.B., p. 42].

Comme c'était loin tout cela! comme c'était loin! [M.B., p. 63].

Comme le bal déjà lui semblait loin! [M.B., pp. 77-78].

$\mathrm{Oh}$ ! comme c'était loin [M.B., p. 424].

Alors Frédéric se rappela les jours déjà loin [L'Ed.S., p. 299].

\section{Maupassant}

Comme c'était loin, comme tout était changé, comme l'avenir lui semblait différent! [U.V., p. 245].

Comme c'était loin, comme c'était loin, le temps où elle parcourait ce même pays, jeune fille, et grise de rêves [U.V., p. 303].

Comme c'était loin, déjà! [M.-O., p. 207].

Que c'est loin! que c'est loin! [O.P., I : Corr., p. 97].

Ces jours passés, si loin, si loin! [O.P., I: Fini, p. 238].

In Madame Bovary the man with the music box and the automatons and in Une Vie old "père Lastique" send forth from time to time "un long jet de salive brune."280

One of the most striking descrptions in Flaubert is that of the glance of Dr. Larivière. There are two similar passages in Maupassant.

\section{Flaubert}

Son regard, plus tranchant que ses bistouris, vous descendait droit lans l'âme et désarticulait tout

\section{MAUPASSANT}

Of the judge in Un Fou it is said: "il semblait lire an fond de leurs âmes, leurs pensées secrètes, et

278 For example, "Cette passion merveilleuse qui jusqu'alors s'était tenue comme un grand oiseau au plumage rose planant dans la splendeur des ciels poétiques" (p. 55) ; "Le suisse, alors, se tenait sur le seuil ... plus majestueux qu'un cardinal et reluisant comme un saint ciboire" (p. 330); etc.

279 B.-A., p. 38I ; for example, Corr., IV, 108.

${ }^{280} M . B .$, p. $90 ;$ U.V., p. 46. 
FLAUBERT

mensonge à travers les allégations et les pudeurs [M.B., p. 442].

\section{MAUPASSANT}

démêler, d'un coup d'oeil, tous les mystères de leurs intentions" [M. Par., p. 16I].

Of the literary man Maupassant says: "il désarticule tous les ressorts cachés des sentiments et des actions des autres" [S.l'E., p. 82]. ${ }^{281}$

In L'Education sentimentale there is a picture of fantastically shaped rocks which has several counterparts in Maupassant.

\section{Flaubert}

Elles [-les roches] se multipliaient de plus en plus, et finissaient par emplir tout le paysage, cubiques comme des maisons, plates comme des dalles, s'étayant, se surplombant, se confondant telles que les ruines méconnaissables et monstrueuses de quelque cité disparue. Mais la furie même de leur chaos fait plutôt rêver à des volcans, à des déluges, aux grands cataclysmes ignorés. ...

... çà et là, tels que des promontoires sur le lit desséché d'un océan, se levaient des roches ayant de vagues formes d'animaux, tortues avançant la tête, phoques qui rampent, hippopotames et ours [L'Ed. S., p. 467].

(These last-named rocks are seen here and there scattered over a sandy hill.)

\section{Maupassant}

Hauts jusqu'à trois cents mètres, minces, ronds, tortus, crochus, difformes, imprévus, fantastiques, ces surprenants rochers, semblaient des arbres, des plantes, des bêtes, des monuments, des hommes, des moines en robe, des diables cornus, des oiseaux démesurés, tout un peuple monstrueux, une ménagerie de cauchemars pétrifiée par le vouloir de quelque Dieu extravagant [U.V., pp. 104-5].

... ils aperçurent ... à mi-côte à peu près, un surprenant chaos de rochers énormes, écroulés, renversés, entassés les uns sur les autres dans une espèce de plaine herbeuse et mouvementée. ... Sur cette longue bande de broussailles et de gazon ... les rocs tombés semblaient les ruines d'une grande cité disparue qui regardait autrefois l'Océan ... [P.e.J., pp. 150-51].

Je m'arrêtai d'abord stupéfait devant ces étonnants rochers de granit rose, hauts de quatre cents mètres, étranges, torturés, courbés, rongés par le temps, sanglants sous

${ }^{281}$ Cf. Balzac's emphasis on "regard," as in César Birotteau. 
Flaubert

\section{MAUPASSANT}

les derniers feux du crépuscule et prenant toutes les formes comme un peuple fantastique de contes féeriques, pétrifié par quelque pouvoir surnaturel.

J'aperçus alternativement deux moines debout, d'une taille gigantesque; un évêque assis, crosse en main, mitre en tête; de prodigieuses figures, un lion accroupi au bord de la route, une femme allaitant son enfant et une tête de diable immense, cornue, grimaçante, gardienne sans doute de cette foule emprisonnée en des corps de pierre [Au S.: En Corse, p. 202].

The following points of likeness between these descriptions are observable. A general impression is given in each of a remarkable chaos of huge and fantastic rocks. In the Flaubertian description and in that from Pierre et Jean these are said to be piled one upon another and to resemble the ruins of some great vanished city. In the last part of the Flaubert description and in the first and third passages from Maupassant some of the rocks take the forms of animals. In the second extract from each of the authors the rocks are seen on the slope of a hill. The adjective "monstrueux" is used by Flaubert and in the quotation from Une Vie.

There are also many examples of the employment of similar locutions, such as "sans doute" ${ }^{282}$ of similar adjectives, such as "énorme" 283 (a great favorite with Flaubert and very frequent in Maupassant); of other similar words, such as "frisson" and its de-

282 For example, Sal., pp. 66, 133, 151, 158, 232, 260, 373; L'Ed.S., pp. 15, $60,79-80,98,103,109,147,240,363,369,375,378,388,393,399,400,405$, 409, 421, 433, 434, 449, 460, 46I, 462, 474, 482, 491, 503, 512, 527, 531, 550, 578, 584, 585, 590-91 ; B.d.S., pp. 13, 24, 36, 42, 48, 57; L.S.R., pp. 165, 272 ; M.Par., pp. 46, 53, 65, 85, 115, 119, 124, 157, 207, 234, 268, 275; L.M.G., pp. 17, 126, 130, 134, 146, 147, 193, 194, 255, 261 ; P.e.J. pp. 116, 121, 139, 140, 169, 226, 236; etc.

283 For example, L'Ed.S., pp. 52, 388, 410, 457, 466, 608; L.M.T., pp. 51, 202; M.Har., pp. 157, 160; Toine, p. 139; C.d.J.e.d.l.N., p. 222; etc. 
rivatives and equivalents. ${ }^{284}$ The word "dégringoler," used in figure by Flaubert, is repeated by Maupassant in one special figure, which he employs several times. ${ }^{285}$ It is that in which he describes a town on a slope as "une vraie cascade de maisons blanches dégringolant à la mer."

In the use of figures there are a number of resemblances between Flaubert and Maupassant.

The "ribbon" figure is frequently found in both.

\section{Flaubert}

La grande route qui étendait sans en finir son long ruban de poussière [M.B., p. 46].

C'est un vaste rectangle, laissant voir ... ses rubans de $\mathrm{bu}$ is ... [L'Ed.S., p. 462].

\section{MaUpassant}

Par la fenêtre, on découvrait un long ruban de rivière ... [M.Har.: L'Héritage, p. 158].

Les longues feuilles bruissaient, pareilles à des rubans jaunes [ $U$. $V$., p. 205].

Related to the above is the "serpent" figure. ${ }^{286}$

Elle [= la rivière] était gelée, le $\mathrm{La}$ Seine ... coulait vers Maisoleil donnait dessus, c'était comme sons-Laffitte, comme un immense un grand serpent d'argent arrêté serpent couché dans la verdure sur l'herbe [O.d.J., III, p. 36]. [B.-A., p. 534]. ${ }^{287}$

Another comparison found in both authors is that of anything bright red in color, such as the sky at sunset, poppies in a field, etc., to "sang."

\section{Flaubert}

Les flambeaux répandus par terre brûlaient encore, en allongeant çà et là sur les pavés de nacre comme des taches de sang [Sal., p. $160]$.

\section{Maupassant}

On est ... exalté lorsque le soleil se noie dans un océan de nuages sanglants et qu'il jette aux rivières des reflets rouges [M.Har., p. 6].

Le soleil baissait vers l'horizon, inondant de clarté les plaines ver-

284 For example, L'Éd.S., pp. I3, 71, 229, 404, 420, 499, 512, 526, 595; B.d.S., pp. 12, 31, 38, 57, 70; L.M.T., pp. 27, 27, 35, 35, 102, 108, 112; L.H., pp. 5, 8, 9, 30, 35, 44, 46, 210, 212, 218, 273, 276, 280, 281, 283; M.-O., pp. 44, 63, I16, I29, I4I, I43, I55, I55, 173, I87, I89, 208, 208, 208, 245, 306, 349, 351, 378, 405, 410, 423; etc.

285 Corr., I, 390 ; cf. M.B., p. 194, and B.e.P., p. 360; L.M.G.: Un Soir, p. 128; cf. B.-A., p. 55 ; Au S.: Alger, p. 14, La Kabylie, p. 165.

${ }^{286}$ Cf. M.B., p. 37 ; T.C.: U.C.S., p. 14 (scarf figure) ; C.d.J.e.d.l.N.: Rose, p. I6; M.Par., p. $60 ; B .-A .$, pp. 316, 335 (ribbon figure).

287 Cf. also O.d.J., III, I40; M.Par., pp. 60-61 ; L.H., p. 254; F.c.l.M., p. I16; O.P., II, 49. 
FLAUBERT

Maupassant

doyantes, tachées de place en place par l'or des colzas en fleur, et par le sang des coquelicots [U.V., p. 379]. ${ }^{288}$

A few additional likenesses in figures are as follows:

Flaubert

... quelquefois les abeilles, tournoyant dans la lumière, frappaient contre les carreaux comme des balles d'or rebondissantes [M.B., p. 239].

Il accomplissait sa petite tâche quotidienne à la manière du cheval de manège, qui tourne en place les yeux bandés, ignorant de la besogne qu'il broie [M.B., pp. IO-II].
MAUPASSANT

Un gros insecte ... battait les murs comme une balle [U.V., p. 238].

Elle ... passa le reste du jour ...aussi rompue et exténuée que si, à la place du vieux cheval blanc, on lui eût fait tourner depuis l'aurore la machine à battre le grain [L.M.T.: L'h.d'u.f.d.f., p. 81]

The following figure is inverted in Maupassant from its use in Flaubert :

\section{Flaubert}

... les jardins, comme des femmes, semblent faire leur toilette pour les fêtes de l'été $[M . B .$, p. I53].

\section{MAUPASSANT}

La vaste plage couverte de monde, de toilettes, de couleurs, avait l'air d'un jardin de femmes [Toine: Bombard, p. 107].

It is not claimed that in this chapter an exhaustive account has been given of all resemblances between Flaubert and Maupassant in plot, incident, characterization, idea, and wording. Many similarities which presented themselves have indeed been rejected for one reason or another. Those included have been observed by the writer in the course of several complete readings of the two authors in question. Further perusal would without doubt reveal others which might be instanced. The attempt has been made all through to call attention especially to the likenesses which are striking or at least fairly close. These may not, as indeed they hardly appear to do, argue for the most part conscious imitation of Flaubert by Maupassant; they certainly do seem to show a considerable degree of suggestive influence.

${ }^{288}$ Cf. also L.M.T.: L'h.d'u.f.d.f., p. 97 ; Mlle F., p. 211 ; L.P.R., p. 34. 


\section{CHAPTER VI}

\section{SUMMARY AND CONCLUSION}

In the preceding pages an attempt has been made to consider the nature and extent of the literary relationship between Flaubert and Maupassant. It had its roots, as we have seen, in a family acquaintanceship, which developed in the course of time into a paternal love and solicitude on the part of the older man, corresponding to an admiring affection on the part of the younger. The literary element was introduced through the master-and-pupil intimacy, which extended over at least seven years. The two men were further bound together by similarities of experience which led them to cherish much the same theories regarding life. Like literary tenets were also held by both. Such resemblances in attitude toward the world and literature seem to be attributable, in part at least, to personal intercourse between the two writers.

In practice the likeness between the works of the authors in question may be traced with comparative clearness. There is to be noted, first of all, an embodiment therein of the similar general and literary theories which have been seen to be definitely stated by both. There is, further, an employment by each of ordinary realistic procédés, some of which may come from the older man to the younger, as well as of certain procedures less usual, which the one may well derive from the other. In the actual content and form of the works of the two there are numerous and often striking similarities, a whole train of likenesses in Maupassant being started sometimes by a single suggestion in Flaubert. A certain lack of inventiveness discoverable on study of the disciple's works would tend to confirm the belief in such an influence of the master as would help to counteract the limitations imposed by a peculiarity of the kind.

The nature of the influence has become sufficiently apparent in the preceding pages: it is seen to include both general resemblance and specific likeness. It does not, however, express itself in set imitation. Rather it seems as if the pupil, trained for years by the master, and brooding, as he must have done, both during that period and in 
subsequent days of remembrance, over the monuments of that master's achievement, had absorbed so thoroughly the essentials of the latter's thought and expression that he reproduces them almost unconsciously. What strengthens the argument for the suggestive type of influence is the frequent difficulty experienced in putting side by side the exact points of resemblance between two passages which impress one as closely similar. The fact that both men expressed themselves in so many words as opposed to the imitation of one author by another would lend further weight to the contention that the kind of influence traceable between the two men is suggestive rather than imitative.

It goes without saying that a considerable portion of Maupassant's work is, of course, distinctively his own. Other influences besides that of Flaubert are also seen to have operated upon him. We have said more than once already, for instance, that Flaubert and Maupassant were men of their day and generation and susceptible to impressions of current thought and event. They belonged to a circle which discussed literary matters and other affairs of the day with the utmost freedom. Evidences of effects produced by realistic writers other than Flaubert are discoverable in the works of the younger man. Many of these authors are mentioned by him with words of intimacy or of admiration. There are also many outstanding points of similarity between their work and his. The following instances are given. From Balzac may come accounts of business transactions and of magnetism, and types of character, such as the financial magnate and the ruthless adventurer, as well as a certain element of driving force in many stories. To Zola may possibly be attributed the tendency to "mention the unmentionable with the greatest possible fulness." He may also be partly responsible for Maupassant's treatment of crowds and use of symbols. Suggestions of Daudet are to be found in the employment of southern exclamations, in the description of M. Patissot's paraphernalia, which makes us think of Tartarin (O.P., II, I2), in a frequent tenderness toward children, and in the repetition of certain incidents. There are other writers also who might be named in connection with the question of Maupassant's indebtedness, but those already referred to will suffice by way of example. When all allowances have been made, however, it yet remains true that Maupassant is the disciple of Flaubert and owes to that master's influence much that is best in his own work. 


\section{BIBLIOGRAPHY}

Flaubert, Gustave. Oeuvres complètes. I8 vols. Paris: Conarả, r9ı Maupassant, Guy de. Oeuvres complètes. 29 vols. Paris: Conard, 190819ro.

For general bibliography see the following:

Descharmes, René, et Dumesnil, René. Autour de Flaubert, II, 183-326. Paris, I912.

Lanson, Gustave. Manuel bibliographique de la littérature française moderne. Vol. IV, Révolution et dix-neuvième siècle. Paris, IgI2. Thieme, Hugo P. Guide bibliographique de la littérature française de I800 à 1906. Paris, I907.

Besides the foregoing, the following books and articles have been consulted, among others, in preparation for this dissertation. The dates are those of the editions used.

Ahlström, Anna. Etude sur la langue de Flaubert. (Diss.) Mâcon, I899. Albalat, Antoine. La Formation du style par l'assimilation des auteurs. 2d edition. Paris, I902.

- Le Mal d'écrire et le Roman contemporain. Paris, 1895.

- "Les Romans contemporains et les pronostics de Sainte-Beuve," La nouvelle Revue, LXXXVI (I894), 317-37.

- Le Travail du style enseigné par les corrections manuscrites des grands écrivains. Paris, 1903. (Contains "Le Travail du style dans Gustave Flaubert," reprinted from Revue bleue, XVIII [1902], 742$47,780-84$.)

Almiras, H. d'. Avant la Gloire. Leurs débuts, I. Paris, 1902. (Guy de Maupassant, pp. 66-72.)

Asselineau, Charles. "L'Education sentimentale," etc., Bulletin du bibliophile (1870-71), pp. 35-42.

Barbey d' Aurevilly, Jules. Les Oeuvres et les hommes, IV. Paris, 1865. (M. Gustave Flaubert, pp. 6I-76.)

- Le Roman contemporain. Paris, I902. (For Flaubert, see pp. 9I-I35.)

Baudelaire, Charles. L'Art romantique. Oeuvres complètes, III. Paris, I868-70.

Beaunier, André. "Flaubert," Revue des deux-mondes (January, I913), pp. 205-16. 
Bertrand, Louis. "Les Carnets de Gustave Flaubert," Revue des deuxmondes, July 15, 1910, pp. 371-92.

- "Le cinquantenaire de Salammbô," Revue des deux-mondes, June I, 1912, pp. 570-98.

- "Flaubert et l'Afrique," Revue de Paris (April I, 1900), pp. 599-624.

- Gustave Flaubert (avec des fragments inédits). Paris, IgI2.

Blaze de Bury, Mlle Yetta. French Literature of To-day. Boston, I898.

-. "Maupassant," New Review, V (I89I), 63-7I.

Blossom, F. A. La Composition de Salammbô d'après la correspondance de Flaubert (1857-1862) avec un essai de classement chronologique des lettres. Elliott Monographs, III. Baltimore and Paris, 1914.

- "La Correspondance de Flaubert," Revue d"histoire littéraire de la France, 1913 (I), pp. 194-97.

Bossom, O. Guy de Maupassant, quelques recherches sur sa langue. (Diss.) Lund, 1907.

Bourget, Paul. Essais de psychologie contemporaine (Oeuvres complètes. Critique I), pp. 97-147; Appendixes A, B. Paris, 1899.

- Etudes et Portraits, I. (Gustave Flaubert, pp. 125-38.) Paris, I889.

Bournon, Fernand. "Le Manuscrit de Salammbô," L'Amateur d'autographes, September 15, 1902.

Bovet, Ernest. "Le Réalisme de Flaubert," Revue d'histoire littéraire de la France, I9I I (I), pp. I-36.

Brandes, Georg. "Gustave Flaubert," in Eminent Authors of the Nineteenth Century (New York, 1886), pp. 259-309.

-. "Maupassant," Revue bleue, XLVIII (I89I), 329-35.

- Moderne Geister. Frankfurt a. M., 2d edition, 1887. (Gustav Flaubert.)

Brunetière, Ferdinand. "Le Pessimisme dans le roman. Bel-Ami de Maupassant, Cruelle enigme de Bourget," Revue des deux-mondes, LXX (1885), 214-27.

- Le Roman naturaliste. (Especially pp. 29-51, 161-220, 342-44, 397-420.) Paris, 1883. (Quotations made from edition of 1892.)

- "Trois Romans," Revue des deux-mondes, $\operatorname{LXXX}$ (1887), 202213.

Canat, René. Du Sentiment de la solitude morale chez les romantiques et les parnassions. Paris, 1904. 
Caro, E. Poètes et romanciers. Paris, 1888.

Cassagne, Albert. La Théorie de l'art pour l'art en France chez les derniers romantiques et les premiers réalistes. Paris, 1906.

Châtel, Gustave. "Maupassant peint par lui-même," Revue bleue, VI (I896), 4I-48.

Claveau, Anatole. "Salammbô," Revue contemporaine, LXV (1862), 643-52.

Coleman, Algernon. "Some inconsistencies in Salammbô," Modern Language Notes, 1912, pp. 123-25.

- Flaubert's Literary Development in the Light of His "Mémoires d'un fou," "Novembre," and "Education sentimentale" (Version of 1845). Elliott Monographs, I. Baltimore and Paris, I9I4.

Commanville, Caroline. Souvenirs sur Gustave Flaubert. See Madame Bovary, Conard edition.

Conrad, M. Französische Charakterköpfe, second series, pp. 3I-45. Leipzig, I88I.

"Correspondance de Gustave Flaubert," Revue bleue, 1887, 1889, on publication of Charpentier edition, pp. 236-41, 268-73.

Cuvillier-Fleury, A.-A. Dernières Etudes historiques et littéraires, $\mathbf{I}$. Paris, 1859. (M. Gustave Flaubert ou le roman réaliste, pp. 352-66.)

Daudet, Mme Alphonse. Souvenirs autour d'un groupe littéraire. Paris, I910.

Daudet, L. "Gustave Flaubert," La nouvelle Revue, LXXIX (I892), 799-803.

Delille, Ed. Some French Writers. (Maupassant, pp. 84-130.) (Reprinted from Fortnightly Review, LVIII [1892], 50-68, with corrections and additions.) London, 1893.

Deschamps, Gaston. La Vie et les livres, I. Paris, I894. (Sur la mort de Guy de Maupassant, pp. 167-78.)

Descharmes, René. "Le Coeur de Flaubert" (account of letters to Mme. L. Colet), Annales romantiques, IX (1912), 225-29.

- "Le 'Dictionnaire des idées reçues' dans l'oeuvre de Gustave Flaubert," Revue d'histoire littéraire de la France, 1914, pp. 280-308.

^_. Flaubert, sa vie, son caractère, ses idées avant $\mathrm{I} 857$. (Lille diss.) Paris, 1909.

- "Saint Julien l'Hospitalier et Pécopin," Revue biblio-iconographique (1905), pp. I-7.

Descharmes, René, et Dumesnil, René. Autour de Flaubert. 2 vols. Paris, 1912.

Desprez, Louis. L'Evolution naturaliste. Paris, I884. 
Doublet, Georges. La Composition de Salammbô d'après la correspondance de Flaubert. Toulouse, 1894.

Doumic, René. Ecrivains d'aujourd'hui. (Guy de Maupassant, pp. 4796.) Paris 1894.

Du Camp, Maxime. Souvenirs littéraires. 2 vols. Paris, 1882-83.

Dumesnil, G. L'Ame et l'évolution de la littérature des origines à nos jours. 2 vols. Paris, 1903. (Pp. 212-25).

Dumesnil, René. Flaubert, son hérédité, son milieu, sa méthode. (Flaubert et la médecine.) (Diss.) Paris, 1905.

Dupin, L. A. Correspondance entre George Sand et Gustave Flaubert. Paris, 1904.

Duplais, Léonie. Etudes littéraires. (Gustave Flaubert, romancier.) Paris, 1906.

Emma. “Gustavo Flaubert," Nuova Antologia, XIV (1879), 302-18.

Faguet, Emile. Gustave Flaubert. Second edition. Paris, I906.

- "Pages choisies de Flaubert," Revue bleue, V (1896), I17-20.

- Propos littéraires, III (Les corrections de Flaubert, pp. I19-30; Guy de Maupassant, pp. 195-209; Tolstoï et Maupassant, pp. 211-25); V (la physiologie de Flaubert, 343-55.) Paris, 1905.

Fay, P. B., and Coleman, A. Sources and Structure of Flaubert's "Salammbô." Elliott Monographs, II. Baltimore and Paris, IgI4.

Ferrère, E.-L. Dictionnaire des idées reçues ... avec une introduction et un commentaire. Paris, I9I3.

- L'Esthétique de Gustave Flaubert. Paris, I9I3.

Fischer, Wilhelm. Etudes sur Flaubert inédit. Leipzig, 1908.

- Flauberts Versuchung des heiligen Antonius nach ihrem Versprung, ihren verschiedenen Fassungen und in ihrer Bedeutung für die Dichter. Marburg, 1903.

Fisher, W. "Maupassant," Temple Bar, CIII (1894), 495-506.

"M. G. Flaubert et M. G. Froehner à propos de Salammbô," Revue contemporaine, LXVI (1863), 413-24.

"Gustave Flaubert," "Lettre inédite" (pp. 65-66), "Paysages de Grèce." (pp. 358-7I), Annales romantiques, I9II.

"Flaubert," etc., Quarterly Review, CLXXI (I890), 57-90, 69-76.

"A Note on Flaubert," Atlantic Monthly, L (I882), 27 I-74.

Fontaine, C. "Les Conteurs français du XIXe siècle: Maupassant, J. Rameau," Modern Language Notes, VI (I891), 472-75.

France, Anatole. La vie littéraire: I (Paris, 1888), Gustave Flaubert, pp. I8-27, M. Guy de Maupassant, pp. 28-35, M. Guy de Maupassant et les conteurs français, pp. 47-58; III (1892), les idées de Gustave Flaubert, pp. 298-308. 
Froehner, G. "Le Roman archéologique en France," Revue contemporaine, LXV ( 1862 ), 853-70.

Gaucher, Maxime. Causeries littéraires. (Maupassant.) Paris, 1890.

- "Tentation de Saint Antoine," Revue bleue, XIII (1874), 977-79.

Gaultier, Jules de. Le Bovarysme. La Psychologie dans l'œuvre de Flaubert. Second edition. Paris, 1903.

—. La Philosophie du Bovarysme. Paris, I9II.

- "Le Bovarysme de Salammbô," Mercure de France, CIII (I9I3), $3 \mathrm{I}-40$.

Gauthiez, Pierre. "A propos de Flaubert," Revue bleue, XLVI (1890), 693-97.

Geiger, L. Dichter und Frauen. (Guy de Maupassant, pp. 341-73.) Berlin, 1896.

Gilbert, Eugène. Le roman en France pendant le dix-neuvième siècle. (Le réalisme de Gustave Flaubert, pp. 154-68; Guy de Maupassant, pp. 426-3I.) Fifth edition. Paris, 1909.

Goncourt, Edmond et Jules de. Journal des Goncourt. Mémoires de la vie littéraire. I-IV, I887-90; V-IX, I89I-96. Paris. (See Index.)

Gould, George M., M. D. A Biographic Clinic on Gustave Flaubert. (Reprinted from Medical Record.) Philadelphia, 1906.

Grappin, H. "Le Mysticisme et l'imagination de Gustave Flaubert," Revue de Paris, i912 (6), pp. 609-29, 849-70.

Gregh, F. "Les oeuvres posthumes de Guy de Maupassant," Revue bleue, XV (1901), 465-67.

Halpérine-Kaminsky. Zola, Dumas, Maupassant. (Translation of Léon Tolstoi) Paris, 1890.

Hannigan, D. F. "Gustave Flaubert," Westminster Review, CXLIV (I895), 383-92.

Heller, H. "Die Entwickelung der neuesten Romandichtung in Frankreich," Zeitschrift für neufranzösische Sprache und Literatur, X, pp. 308-54.

"Der Naturalismus in der Romandichtung Frankreichs und Deutschlands," Zeitschrift für neufranzösische Sprache und Literatur, VI, 297-3I9.

Hennequin, Emile. Etudes de critique scientifique. (Gustave Flaubert, pp. I-68.) Paris, I8go.

Houssaye, Henry. Les hommes et les idées. (Gustave Flaubert, pp. 18520I.) Paris, I886. 
Huet, G. "Saint Julien l'Hospitalier," Mercure de France, CIV (1913), 44-59.

Hugues, G. d'. "Gustave Flaubert d'après sa correspondance," Le Correspondant, CLXX (1893), 877-90.

James, Henry. French Poets and Novelists. London. 1878. (Gustave Flaubert, pp. 252-68.)

- "Gustave Flaubert," Macmillan's Magazine, LXVII (I892-93), 332-43. (On correspondence.)

- Introduction to Thirteen Tales by Guy de Maupassant. New York and London. No date.

- "Maupassant," Fortnightly Review, XLIX (1888), 364-86.

- "The Minor French novelists (de Bernard, Goncourt, Flaubert)," The Galaxy, XXI (1876), 219-33.) (Flaubert, pp. 224-29.)

- Partial Portraits. London, 1888.

Kahn, Gustave. "L'Ironie dans le roman français," La nouvelle Revue, XXIV (1903), 528-34.

-. "Le roman bourgeois," La nouvelle Revue, XIX (I902), 345-92.

Klincksieck, Friedrich. Zur Entwickelungsgeschichte des Realismus im französischen Roman des XIXten Jahrhunderts. Marburg and Paris, I89I.

Koppel, E. "Maupassant," Nord und Sïd, LXIII (1892), 352-62.

H.-L. "Petites Notes vétilleuses sur Madame Bovary," Revue d'histoire littéraire de la France, 1910 (2), pp. 395-97.

Lacassagne, Zacharie. La Folie de Maupassant. (Diss.) Toulouse, I907.

Lang, Andrew. "French Novels and French Life," North American Review, CLIV (1892), 27-32.

Lanson, Gustave. Etude sur Flaubert en tête de pages choisies. Paris, 1895 .

Laroze, Lionel. "Rabelais et Flaubert," Revue des études rabelaisiennes, I910, pp. 93-94.

Larroumet. "Maupassant," Revue bleue, XI (1899), 321-27.

Lastic, Philibert de. La Pathologie mentale dans les oeuvres de Gustave Flaubert. (Diss.) Paris, 1906.

Laujol, Henri. "Deux articles sur Gustave Flaubert," Revue blene (February 22 and March I, 1890).

Leblond. "Le Roman et la science," Revue universelle, II, 425-27, 465-69.

Lefranc, Jean. "Flaubert et Mlle Bosquet," Annales romantiques (I9I I), pp. $195-203$.

Lehmann, Rudolf. Die Formelemente des Stils von Flaubert in den Romanen und Novellen. Munich, 1908. 
Lemaitre, Jules. Les Contemporains, I (1885), Guy de Maupassant, pp. 285-310; V (1892), G. d. M., pp. I-I2; VI (I896), G. d. M., pp. 35I-59.

_. "M. G. Flaubert: ses romans de mœurs contemporaines," Revue blene, XXIV (1879), 342-49.

- "M. G. Flaubert: ses romans de mœurs antiques," Revue bleue, XXIV (1879), 36I-67.

Levallois, Jules. Milieu de siècle. Mèmoires d'un critique. Paris, I896. (Pp. 298-300.)

Lévy-Bruhl, L. "Flaubert philosophe," Revue de Paris, 1900 (I), 836-52.

Lindau, Paul. Aus dem literarischen Frankreich. Second edition. Breslau, i882. (Gustave Flaubert, pp. 49-81.)

Loliée, F. "Les disparus: Maupassant," La nouvelle Revue, LXXXIII (1893), 409-13.

Lombroso, A. Souvenirs sur Maupassant, sa dernière maladie, sa mort, avec des lettres inédites communiquées par Madame Lave de Maupassant et des notes recueillies parmi les amis et les médecins de l'écrivain. Rome, 1905.

Lorenz, Max. "Das Problem Maupassants," Preuszische Jahrbïcher, XCII (1898), II6-37.

Madeleine, J. "Les différents Etats de la tentation de saint Antoine," Revue d'histoire littéraire de la France, 1908, pp. 620-41.

Mahn, Paul. Guy de Maupassant, sein Leben und seine Werke. Berlin, I908.

Martino. Le roman réaliste sous le second empire: 2e partie, Autour de Flaubert et de Taine. (Chapter I, "Flaubert, «Madame Bovary.»") Paris, 1913.

Marzials, F. "Gustave Flaubert," The Critic (N. Y.), XLIII (I903), 148-52.

Matthews, Brander. "A Note on Maupassant," The Bookman, XVIII (1903-4), I7I-73.

Mauclair, Camille. L'Art en silence. Paris, 1901. (Flaubert lyrique, pp. 43-7r.)

- . "La Question morale dans le roman," La Revue des revues, XL (1902), 427-37.

Maupassant, Guy de. "Gustave Flaubert dans sa vie intime," La nouvelle Revue, VIII (I88I), 142-47.

"Maupassant" (collection of opinions of Maupassant), Revue encyclopédique, III (1893), 750-58.

Maupassant, Mme Laure de. Lettres à Flaubert. (Vol IX, Conard edition of Maupassant.) 
Maurras, Charles. "Les romanciers et les conteurs," Revue encyclopédique, VIII, 366-72.

- . "Les romanciers et les conteurs de la science et de l'amour," Revue encyclopédique, VIII, 510-17.

Maynial, Edouard, "La Composition dans les romans de Maupassant," Revue bleue, XX (1903), 562-65, 604-8.

-. La jeunesse de Flaubert. Paris, I913.

-. "Maupassant," Le Correspondant, CLXVI (1892), 249-65.

- La vie et l'œuvre de Maupassant. Paris, 1906.

Merlet, Gustave. Portraits d'hier et d'aujourd'hui, II. (Le réalisme physiologique. M. Gustave Flaubert, pp.91-I4I.) Paris, 1863.

Meunier, Georges. Le Bilan littéraire du XIXe siècle. Paris, 1898. (Flaubert especially pp. 261-70.)

Miomandre, F. de. "La Femme dans le roman contemporain," La nouvelle Revue, New Series, XII (I901), 458-65.

Morice, Charles. La Littérature de tout à l'heure. Paris, 1889. (Pp. I75 ff.)

Moselle. "Guy de Maupassant," Revue bleue, (March 21, 19r4), pp. 36570.

Newman, Ernest. “Gustave Flaubert," Fortnightly Review, LXIV (1895), 813-28.

Pajot, Henri. Le Paysan dans la littérature française. Paris, I896.

Palante, Georges. "Le Bovarysme: une moderne philosophie de l'illusion," Mercure de France, XLVI (1903), 69.

Patry, H. "Rabelais et Flaubert," Revue des études rabelaisiennes, II (1904), 27-39.

Pellissier, Georges. "Le Paysan dans le roman français moderne, $\mathbf{L a}$ Revue des revues, XXXV (1900), pp. 485-97

Planche, Gustave. "Le Roman français en 1857 ," Revue des deux-mondes, 1857, pp. 413-33.

Platzhoff, E. "Gustav Flaubert," Nord und Sïd, (January, 1902), pp. 38-60.

Pontmartin, Armand de. Nouvelles Causeries du samedi. Second edition. Paris, I86o. (MM.. Edmond About et Gustave Flaubert, pp. 299326.)

- Nouveaux samedis, VII. Paris, 1870. (Gustave Flaubert, pp. 289-302.) 
Pontmartin, Armand de. Nouvelles semaines litteraires. Paris, I863. (M. Gustave Flaubert, pp. 93-106.)

- Souvenirs d'un vieux critique, II. Paris, 1882. (Gustave Flaubert, pp. 281-95.)

Roujon, H. "Souvenirs d'art et de littérature. Guy de Maupassant," La Grande Revue, I (1904), 249-66.

Rouxière, Jean de la. "Les Origines de Gustave Flaubert," Annales romantiques, I913 (I), p. 23I.

Sachse, J. E. “Gustav Flaubert,” De Gids, 1890 (1), pp. 28-70.

- "Maupassant," De Gids, 1890 (2), pp. 413-61.

Sainte-Beuve. Lundis, XIII. Paris, I858. (Madame Bovary, par M. Gustave Flaubert, pp. 283-97.)

-. Nouveaux Lundis, IV. . Paris, I897. (Salammbô, par M. Gustave Flaubert, pp. 3I-95 [three articles].)

Saint-René-Taillandier. "Le Réalisme épique dans le roman. Salammbô," Revue des deux-mondes, XLIII (1863), 840-61.

- . "Le Roman misanthropique, L'Education sentimentale," R. D. M., LXXXIV (1869), 987-1005.

—. "Tentation de Saint Antoine," R. D. M., III (1874), 224-36.

Saintsbury, George. Essays on French novelists. London, 189I. (Flaubert, Preface, pp. vii-viii, 334-80; Maupassant, pp. 13-16, 25.)

- "Gustave Flaubert," Fortnightly Review, XXIX (1878), 575-95.

Sand, George. Questions d'art et de littérature. Paris, 1878. (Lettre sur Salammbô, pp. 305-12; L'Education sentimentale par Gustave Flaubert, pp. 415-23.)

Schérer, Edmond. Etudes sur la littérature contemporaine, IV. Paris, I873. (Un roman de M. Flaubert, pp. 29I-30I.)

Schinz, A. "Notes sur le vocabulaire de Maupassant et de Mérimée," Revue des langues romanes (1909), pp. 504-3I.

Schmidt, Mlle Bertha. Le Groupe des romanciers naturalistes. Karlsruhe, 1903 .

Seillière, Ernest. Le Romantisme des réalistes, Gustave Flaubert. Second edition. Paris, 19I4.

Spont, Henry. "Gustave Flaubert, Educateur," La Revue (1909), pp. 289-302.

Spronck, Maurice. Les Artistes littéraires. Paris, I889. (Gustave Flaubert, pp. 239-97.)

Tarver, John Charles. Gustave Flaubert as Seen in His Works and Correspondence. London, 1895 . 
Tassart, François. "La Mort de Guy de Maupassant," Revue des deuxmondes, March I, IgIr.

- Souvenirs sur Guy de Maupassant (1883-1893). Paris, I9II.

Tolstoï, L. N. "Maupassant" (Translation), The Arena, XI (1894-95), 15-26.

Trévières, Pierre de. "Les Erreurs de Salammbô," La Grande Revue, 1912 (2), pp. 718-48.

Troubat, J. Essais critiques. (Champfleury, Flaubert, etc.) Paris, I902.

Two French Men of Letters: Flaubert and Barbey d'Aurevilly," Atlantic Monthly LXVIII (I89I), 695-70I.

Ulmès, Mme Renée d'. "Flaubert (souvenirs inédits d'enfance et de jeunesse)," Revue des revues, XXXVIII (I901), I72-79.

- "Guy de Maupassant, détails inédits sur son enfance et sa premiére jeunesse," Revue des revues, XXXIII (1900), 482-95.

- "Les Héroïnes de Maupassant (d'après mes conversations avec Mme Laure de Maupassant)," Revue des revues, XLI (1902), 596-603

- "Les Mères d'artistes (d'après des documents inédits) : Madame Flaubert," Revue des revues, XLIII (1902), 165-73.

- "Les Mères des grands écrivains: Mme Laure de Maupassant," Revue des revues, XLIX (1904), 414-26.

Wassermann, J. Flaubert, ein Selbstporträt nach seinen Briefen. Berlin, Igo6.

Weigand, W. Essays, etc. Munich, 1892. (G. Flaubert, pp. 271-79.)

Weiss, J.-J. Essais sur l'histoire de la littérature française. Paris, 1865.

(De la littérature brutale: Mme Bovary, etc., pp. 8\& 165.)

Wells, B. A Century of French Fiction. New York, 1898.

$\mathrm{X}$, Mme (Mme Louise Colet). "Guy de Maupassant intime. Notes d'une amie," La grande Revue, I912 (5), pp. 673-99.

Zola, Emile. Le roman expérimental. Paris, 1902.

- Les romanciers naturalistes. Paris, I88I.

-U. Une Campagne. Paris, I88I. 



\section{DAY USE}

RETURN TO DESK FROM WHICH BORROWED

LOAN DEPT.

RENEWALS ONLY - TEL. NO. 642-3405

This book is due on the last date stamped below, or on the date to which renewed.

Renewed books are subject to immediate recall.

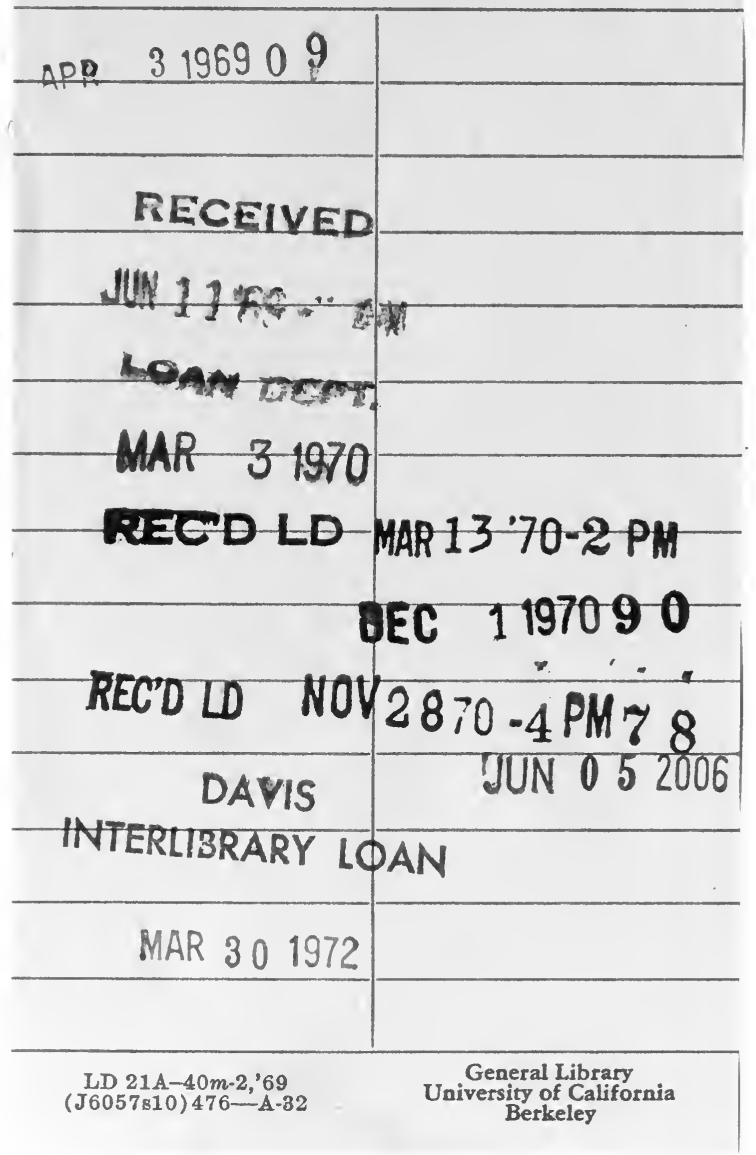




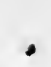

/
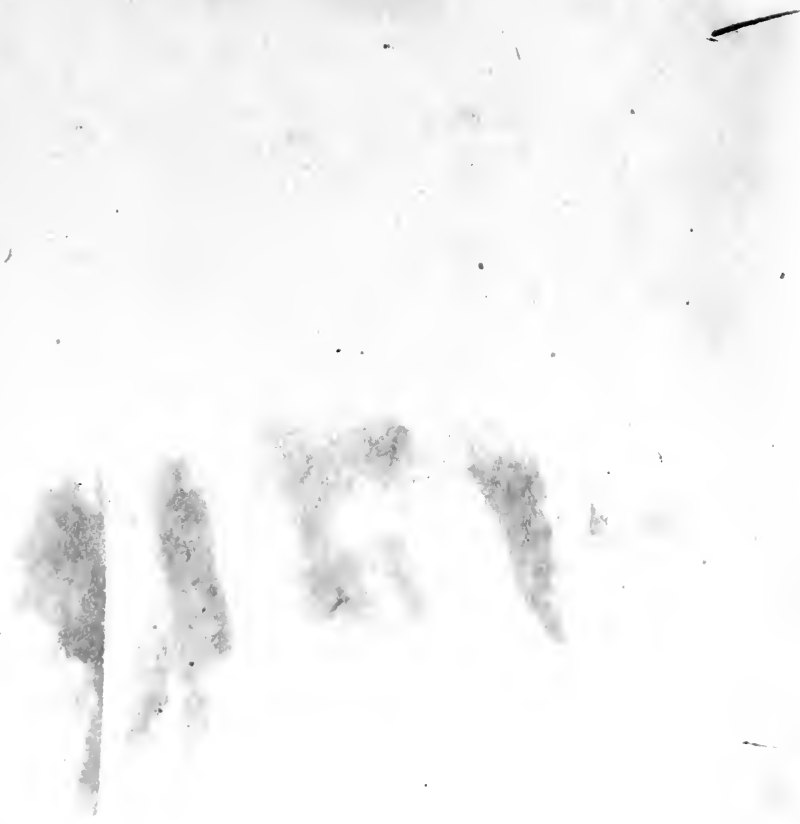

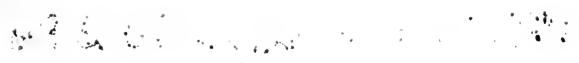

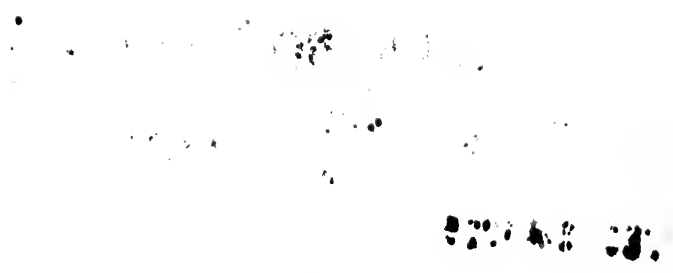




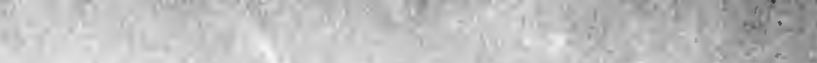

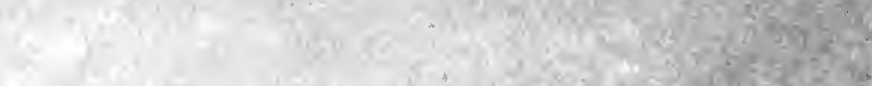

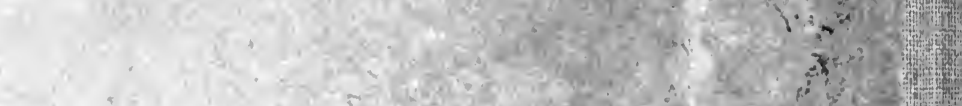

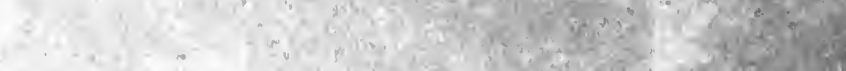

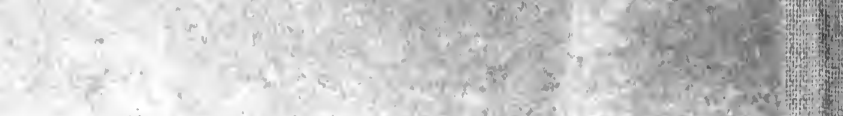
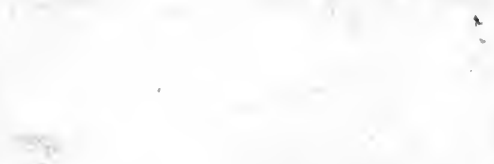

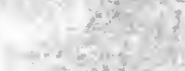

sis

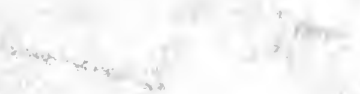

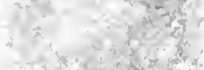

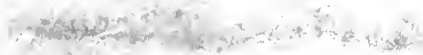

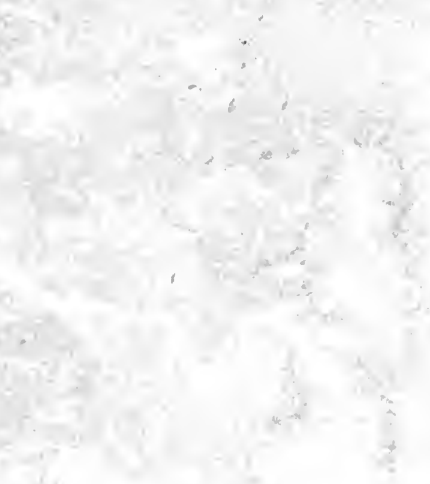

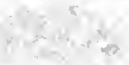

$$
\begin{aligned}
& \text { an }
\end{aligned}
$$

is

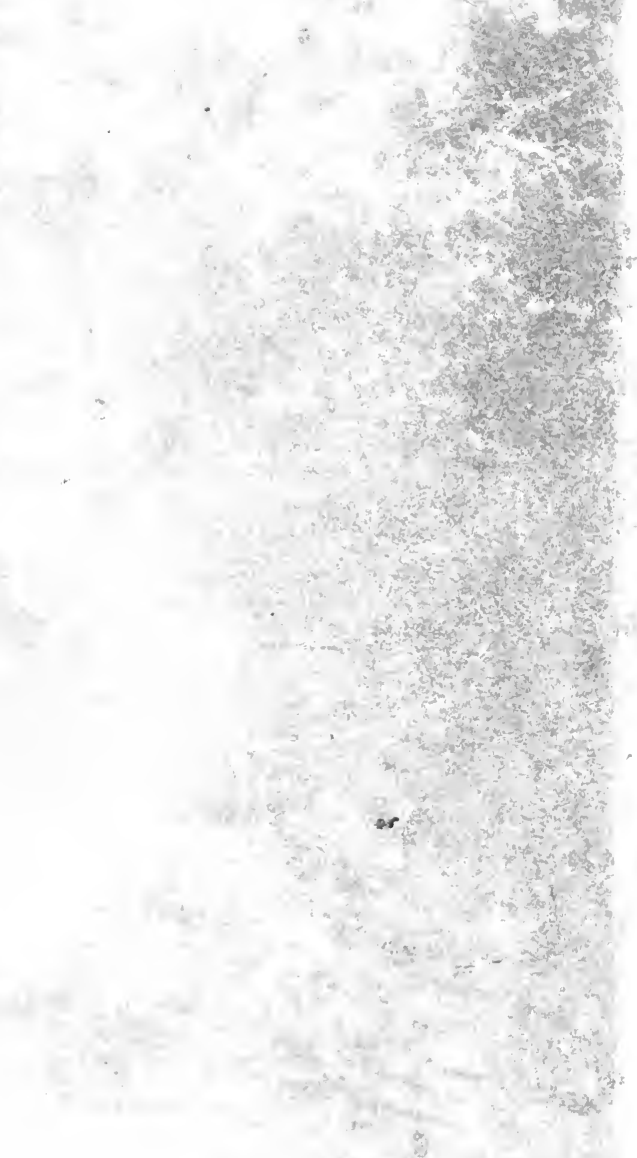

$-2 x^{2}+x^{2}+x^{2}$

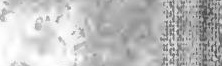

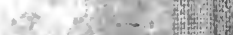

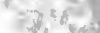

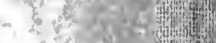

$\therefore-4 x-2$ it

i.

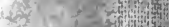

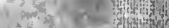

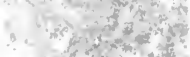
4 $3 x+5$

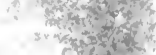
aी 1) this

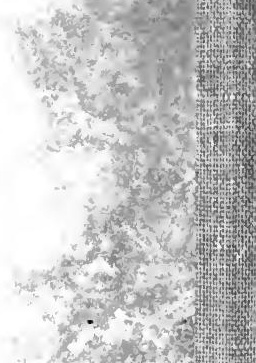

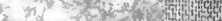
be $>7$ ro : ard

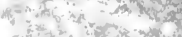
A

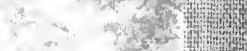

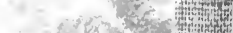
$\therefore-28, x$,

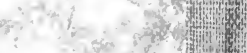

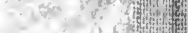

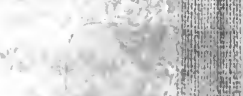

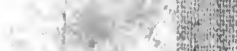

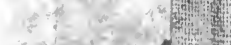

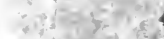

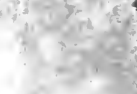
- 3 